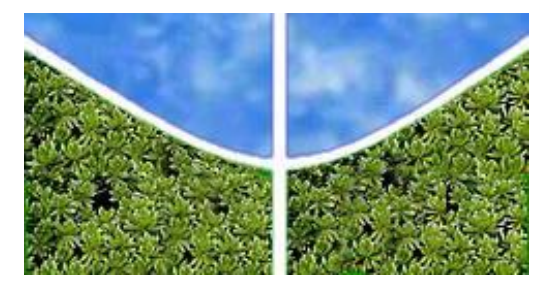

\author{
UNIVERSIDADE DE BRASÍLIA- UNB \\ PROGRAMA DE PÓS-GRADUAÇÃO EM DESENVOLVIMENTO \\ SUSTENTÁVEL \\ MESTRADO ACADÊMICO
}

LINHA DE PESQUISA: GESTÃO DO TERRITÓRIO, USO DA TERRA E ÁREAS PROTEGIDAS

O MOSAICO DO BAIXO RIO NEGRO: CONSERVAÇÃO DA BIODIVERSIDADE E SUSTENTABILIDADE NA AMAZÔNIA

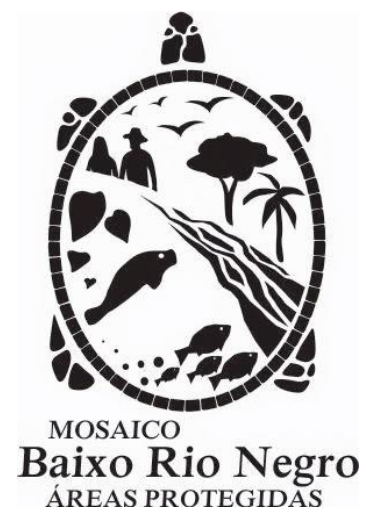

Aluna: Carolina Azevedo de Almeida

Orientador: José Luiz de Andrade Franco

Brasília, dezembro de 2014 
UNIVERSIDADE DE BRASÍLIA

CENTRO DE DESENVOLVIMENTO SUSTENTÁVEL

O Mosaico do Baixo Rio Negro: Conservação da Biodiversidade e Sustentabilidade na Amazônia

Carolina Azevedo de Almeida

Orientador: José Luiz de Andrade Franco

Dissertação de Mestrado

Brasília-DF, 19 de dezembro de 2014 
Almeida, Carolina Azevedo de

O Mosaico do Baixo Rio Negro: conservação da biodiversidade e sustentabilidade na Amazônia/Carolina Azevedo de Almeida

Brasília, 2014

150 p. : il

Dissertação de Mestrado. Centro de Desenvolvimento Sustentável. Universidade de Brasília, Brasília.

1. Mosaicos de Áreas Protegidas. 2. Gestão Biorregional. 3. Mosaico do Baixo Rio Negro. 4. Conservação da Biodiversidade

É concedida à Universidade de Brasília permissão para reproduzir cópias desta dissertação e emprestar ou vender tais cópias somente para propósitos acadêmicos e científicos. O (a) autor (a) reserva outros direitos de publicação e nenhuma parte desta dissertação de mestrado pode ser reproduzida sem a autorização por escrito do(a) autor(a).

Assinatura 


\title{
O Mosaico do Baixo Rio Negro: Conservação da Biodiversidade e Sustentabilidade na Amazônia
}

\author{
Carolina Azevedo de Almeida
}

Dissertação de Mestrado submetida ao Centro de Desenvolvimento Sustentável da Universidade de Brasília, como parte dos requisitos necessários para a obtenção do grau de Mestre em Desenvolvimento Sustentável, área de concentração Política e Gestão Ambiental.

Aprovada por:

José Luiz de Andrade Franco (Centro de Desenvolvimento Sustentável- CDS/UnB) (Orientador)

Cristiane Gomes Barreto, Doutora (Centro de Desenvolvimento Sustentável- CDS/UnB)

Vivian da Silva Braz, Doutora (Centro de Desenvolvimento Sustentável- CDS/UnB)

Brasília, 19 de dezembro de 2014. 
À biodiversidade brasileira, que a todos encanta com sua beleza e riqueza. 


\section{AGRADECIMENTOS}

Para concluir este curso de Mestrado no CDS/UnB, foi preciso percorrer um caminho longo às vezes árduo. Neste percurso, me deparei com conhecimentos novos que contribuíram para que eu ampliasse minha visão de mundo, e que contribuíram para que eu pudesse compreender melhor a gestão e a política ambiental no Brasil.

Nesta caminhada, contei com o apoio de inúmeras pessoas, em diferentes intensidades: parentes, colegas de curso, professores, profissionais da área e servidores da Universidade de Brasília. Gostaria de agradecer a todos eles, em especial:

Ao meu orientador José Luiz de Andrade Franco, pela dedicação e atenção dada ao trabalho desenvolvido para esta dissertação de mestrado e também pela paciência e contribuições.

A todos os professores e servidores do CDS/UnB, que de forma direta ou indireta contribuíram para a realização da presente pesquisa.

A todos os especialistas e gestores de Mosaicos de Áreas Protegidas que participaram desta pesquisa, em especial a Priscila Maria da Costa Santos e a Ana Luiza Figueiredo (ICMbio/Novo Airão- AM).

Ao INCRA, por ter me concedido o tempo necessário para o desenvolvimento desta pesquisa.

A todos os meus colegas de turma do CDS/UnB, que também fizeram parte desta caminhada, pela amizade construída durante o período do mestrado. Espero que juntos possamos contribuir para proteger a natureza da insensatez humana.

A todos os meus familiares pelas palavras de incentivo.

Aos meus pais, Jaime Gonçalves de Almeida e Shirley de Azevedo Silva Almeida, que tanto me ajudaram a trilhar este caminho.

Ao meu filho Henrique Almeida Soares, pelas palavras de incentivo, pela compreensão e pelo carinho.

Obrigada! 


\section{RESUMO}

Os Mosaicos são blocos de unidades de conservação e áreas protegidas públicas ou privadas, de categorias diferentes ou não, próximas, justapostas ou sobrepostas, cuja gestão deve ser feita de forma integrada e participativa. O Mosaico deve considerar os distintos objetivos de conservação das unidades que o compõem, além de compatibilizar a presença da biodiversidade com a valorização da sociodiversidade. Nos mosaicos, o desenvolvimento sustentável deve ser promovido dentro do contexto regional. Esta pesquisa teve por objetivos: compreender os mosaicos como instrumento de gestão ambiental voltado para a conservação da biodiversidade e para a valorização da sociodiversidade e compreender como o Mosaico do Baixo Rio Negro atua nesses propósitos. Os estudos sobre gestão de áreas protegidas, em específico sobre a Gestão Biorregional serviram de base teórica para a presente pesquisa. A investigação foi orientada pela abordagem qualitativa. Para isto, foram realizadas entrevistas semiestruturadas com os gestores do Mosaico, observações em reuniões do Conselho Consultivo e consultas a documentos de gestão do mosaico, além da consulta à bibliografia pertinente ao tema da pesquisa. Os resultados alcançados indicam que o Mosaico do Baixo Rio Negro coloca em prática a gestão integrada, embora de modo incipiente. Além disso, os resultados também demonstram que os mosaicos despontam como uma força política em prol da conservação no Brasil.

Palavras- chave: Mosaicos de Áreas Protegidas, Gestão Biorregional, Mosaico do Baixo Rio Negro, conservação da biodiversidade. 


\begin{abstract}
Mosaics are groups of conservation units and public or private protected areas of the same or of different categories, which are next or beside to each other or overlaped. The management of the mosaic area must be integrated and participatory. It must be considered all the different conservation targets of the units that takes part in the mosaic. The mosaic must also make compatible the presence of biodiversity and the goals to value social diversity. In mosaics, sustainable development must be fostered within the regional context. The purposes of this research are: to understand the mosaics as a tool of environmental management for the conservation of biodiversity and for giving importance to the social diversity and to realize how the Mosaic of Baixo Rio Negro acts for the achievement of such goals. The studies on the management of protected areas, in specific on Bioregional Management, were the theoretical basis of the research. The method used was qualitative. Thus, semi-structured interviews were carried out with managers of the mosaic and observations were made by participation in the meetings of the Counsel of the Mosaic of Baixo Rio Negro. The bibliography on the theme was also consulted. The results achieved suggest that the Mosaic of Baixo Rio Negro putts in practice integrated management of protected areas, although in an incipient way. In addition, the results show that the mosaics emerge as a political power propitious to conservation in Brazil.
\end{abstract}

Key words: Mosaics of Protected Areas, Biorregional Management, Mosaic of the Baixo Rio negro, conservation of biodiversity. 


\section{RESUMÈ}

Mosaïques sont des blocs de zones protégées et des zones protégées publiques ou privées, de différent ou pas, fermez, juxtaposés ou catégories qui se chevauchent, dont la gestion devrait être fait d'une manière intégrée et participative. La mosaïque devrait tenir compte des différents objectifs de conservation des unités composantes, en plus de concilier la présence de la biodiversité à l'appréciation de la diversité sociale. Dans mosaïques, le développement durable doit être encouragée dans le contexte régional. Cette recherche visait à: comprendre les mosaïques comme un outil de gestion de l'environnement visant à la conservation de la biodiversité et l'amélioration de la diversité sociale et de comprendre comment le Lower Rio Negro Mosaic sert ces fins. Études sur la gestion des aires protégées, en particulier sur la gestion biorégionale fourni la base théorique de cette recherche. La recherche a été guidé par une approche qualitative. Pour cela, des entrevues semi-structurées ont été menées avec les gestionnaires de la mosaïque, des observations du Conseil consultatif des réunions et des consultations gestion de documents Mosaic, en plus de consulter la documentation pertinente au sujet de la recherche. Les résultats indiquent que la mosaïque de la Basse Rio Negro met en pratique la gestion intégrée, bien que le mode naissante. En outre, les résultats montrent également que les tuiles apparaissent comme une force politique pour la conservation au Brésil.

Mots clés: Mosaïques de zones protégées, la gestion biorégionale, Mosaïque Lower Rio noir, conservation de la biodiversité. 


\section{RESUMEN}

Los mosaicos son bloques de áreas protegidas y áreas protegidas, públicas o privadas, diferentes o no, cercanos, yuxtapuestos o categorías superpuestas, cuya gestión se debe hacer de una manera integrada y participativa. El mosaico debe considerar los diferentes objetivos de conservación de las unidades que lo componen, además de conciliar la presencia de la biodiversidad con la valoración de la diversidad social. En los mosaicos, el desarrollo sostenible debe promoverse dentro del contexto regional. Esta investigación tuvo como objetivo: entender los mosaicos como una herramienta de gestión ambiental orientada a la conservación de la biodiversidad y la mejora de la diversidad social y entender cómo el Río Negro Mosaico Baja sirve estos fines. Los estudios sobre la gestión de las áreas protegidas, en particular sobre la gestión bioregional proporcionaron la base teórica de esta investigación. La investigación se basó en el enfoque cualitativo. Para esto, entrevistas semi-estructuradas a los gerentes de mosaico, observaciones Consejo Asesor reuniones y consultas Mosaico de gestión de documentos, además de consultar la literatura relevante para el tema de la investigación. Los resultados indican que el mosaico del Bajo Río Negro pone en práctica la gestión integrada, aunque el modo incipiente. Además, los resultados también muestran que los azulejos emergen como una fuerza

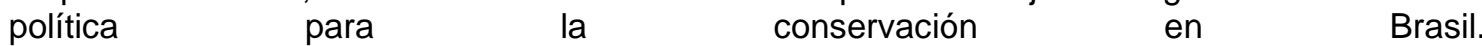

Palabras clave: Mosaicos de Áreas Protegidas, gestión bioregional, mosaico del Bajo Río negro, conservación de la biodiversidad. 


\section{LISTA DE ILUSTRAÇÕES}

1- Mapa do Mosaico do Baixo Rio Negro.............................................72

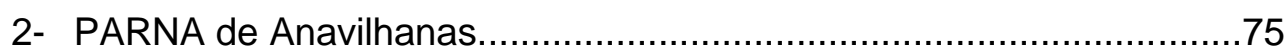

3- Extrativismo da Castanha- da- Amazônia no Baixo Rio Negro..............86

4- Comerciante de Produtos do Extrativismo Animal...............................87

5- Ribeirinhos da RESEX do Unini..........................................................87

6- Mapa da RDS Puranga-Conquista......................................................91

7- Reunião IPÊ/Parceiros.................................................................114

8- Expedição IPÊ- Margem Direita do Rio Negro/Mapeamento dos atores e formação de lideranças.........................................................................115

9- 1a Oficina do Mosaico do Baixo Rio Negro........................................115

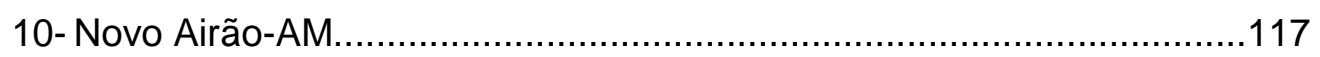

11- Flutuante do PARNA de Anavilhanas..............................................125

12- 9ª Reunião Ordinária do Conselho do Mosaico....................................128

13- Painel Temático da 9ª Reunião do CCMBRN.......................................134 
LISTA DE TABELAS

1- Comparativo do Percentual das Áreas Protegidas no Brasil e no Mundo.....38

2- Unidades de Conservação por Bioma.........................................................38

3- Percentuais de UCs por Grupo de Categoria, por Bioma e Percentual de Terras Indígenas- Tls 


\section{LISTA DE QUADROS}

1- Projetos de Corredores Biorregionais Selecionados pelo PCE em 2005...53

2- Mosaicos Oficialmente Reconhecidos no Brasil..........................................57 


\section{LISTA DE ABREVIATURAS}

AM- Amazonas

AMORU- Associação dos Moradores do Rio Unini

APA- Área de Proteção Ambiental

APP- Área de Preservação Permanente

ARPA- Programa Áreas Protegidas da Amazônia

CAR- Cadastro Ambiental Rural

CCMBRN- Conselho Consultivo do Mosaico do Baixo Rio Negro

CDB- Convenção sobre Diversidade Biológica

CERBAC- Conselho da Reserva da Biosfera da Amazônia Central

CEUC- Centro Estadual de Unidades de Conservação

Cl- Conservação Internacional

CNUC- Cadastro Nacional de Unidades de Conservação

CNUMAD- Conferência das Nações Unidas sobre Meio Ambiente e Desenvolvimento COP- Conferência das Partes

DTBC- Desenvolvimento Territorial de Base Conservacionista

ESEC- Estação Ecológica

FAS- Fundação Amazônia Sustentável

FLONA- Floresta Nacional

FNMA- Fundo Nacional de Meio Ambiente

FOPEC- Fórum Permanente em Defesa das Comunidades Ribeirinhas de Manaus

FUNAI- Fundação Nacional do Índio

FVA- Fundação Vitória Amazônica

GT- Grupo de Trabalho

GTZ- Agência de Cooperação Alemã

IBAMA- Instituto Brasileiro de Meio Ambiente e dos Recursos Naturais Renováveis 
ICMBIO- Instituto Chico Mendes de Conservação da Biodiversidade

INCRA- Instituto Nacional de Colonização e Reforma Agrária

IPÊ- Instituto de Pesquisas Ecológicas

ISA- Instituto Socioambiental

MBRN- Mosaico do Baixo Rio Negro

MMA- Ministério do Meio Ambiente

ONG- Organização não- governamental

PAREST- Parque Estadual

PARNA- Parque Nacional

PCE- Projeto Corredores Ecológicos

PNAP- Plano Estratégico Nacional de Áreas Protegidas

PNJ- Parque Nacional do Jaú

RDS- Reserva de Desenvolvimento Sustentável

RESEX- Reserva Extrativista

RL- Reserva Legal

RPPN- Reserva Particular do Patrimônio Natural

SDS- Secretaria de Meio Ambiente e Desenvolvimento Sustentável do Amazonas

SNUC- Sistema Nacional de Unidades de Conservação

WWF- Fundo Mundial para a Natureza 


\section{SUMÁRIO}

LISTA DE ILUSTRAÇÕES

LISTA DE TABELAS

LISTA DE QUADROS

\section{LISTA DE ABREVIATURAS}

INTRODUÇÃO

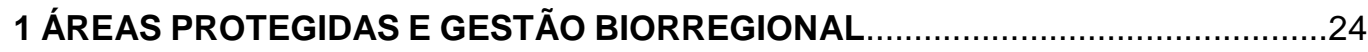

1.1 O SURGIMENTO DA POLÍTICA DE ÁREAS

PROTEGIDAS, A GESTÃO BIORREGIONAL E

OS INSTRUMENTOS DE POLÍTICA BIORREGIONAL

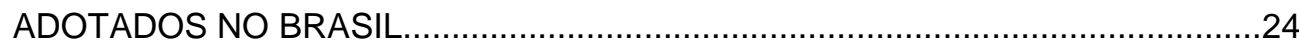

1.2 O CENÁRIO ATUAL DAS ÁREAS PROTEGIDAS

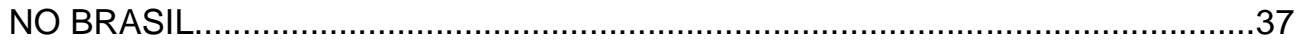

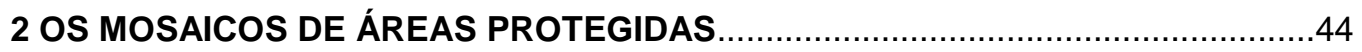

2.1 O CONCEITO DE MOSAICO DE ÁREAS PROTEGIDAS.....................................44

2.2 A PARTICIPAÇÃO SOCIAL NA GESTÃO DE UCS............................................47

2.3 O SURGIMENTO DOS MOSAICOS NO BRASIL..............................................

2.4 MOSAICOS BRASILEIROS: UM CENÁRIO DE

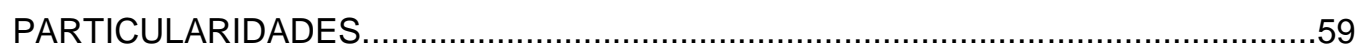

2.5 RELAÇÕES ENTRE FRAGMENTAÇÃO FLORESTAL E

MOSAICOS DE

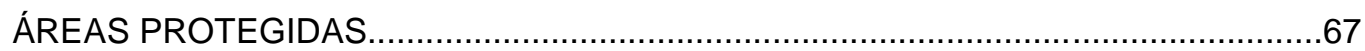

3 A CRIAÇÃO DO MBRN: UNINDO PEÇAS PARA A CONSERVAÇÃO ....................72

3.1 AS UCS DO MBRN: DIVERSIDADE E UNIDADE NO TERRITÓRIO......................72

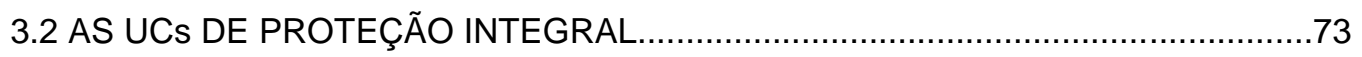

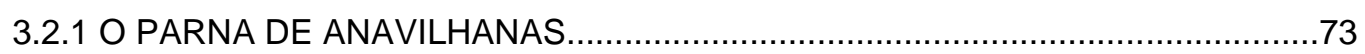

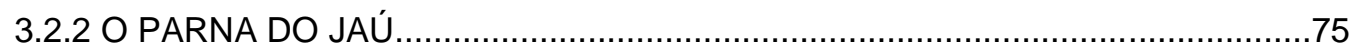

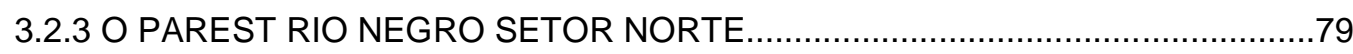

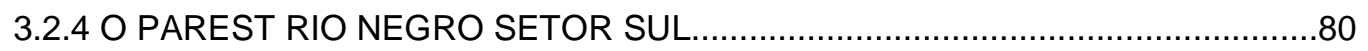

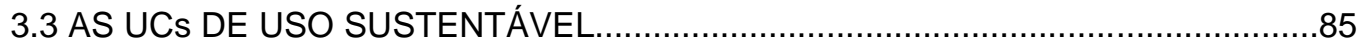

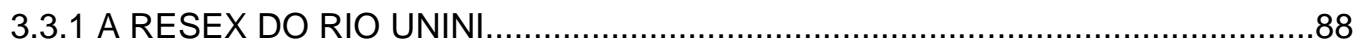

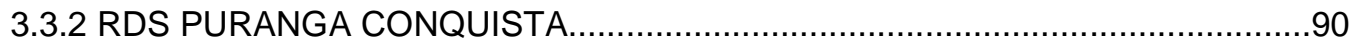

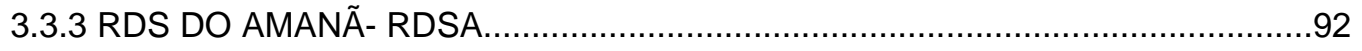

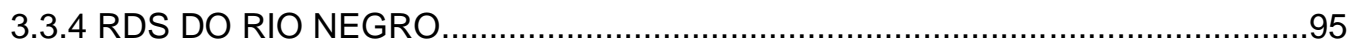

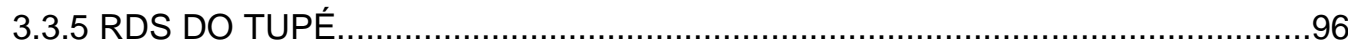

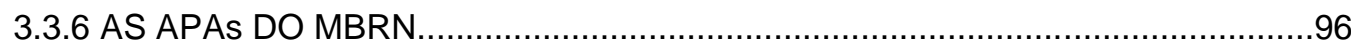

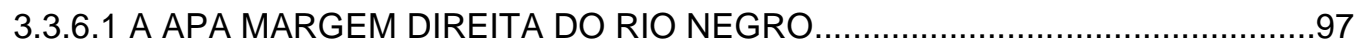


3.3.6.2 A APA MARGEM ESQUERDA DO RIO NEGRO

3.3.6.3 A APA MARGEM ESQUERDA DO RIO NEGRO SETOR ATURIÁ/APUAZINHO. .98

3.3.6.4 A APA MARGEM ESQUERDA DO RIO NEGRO SETOR TARUMÃAÇU/TARUMÃ-MIRIM.

3.4 O CONTEXTO DA POLÍTICA AMBIENTAL NACIONAL E A CRIAÇÃO DO MBRN....... 100

3.5 PERCEPÇÕES DOS ATORES SOBRE O PROCESSO DE CRIAÇÃO DO MOSAICO. 102

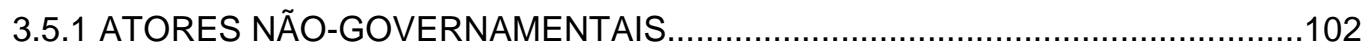

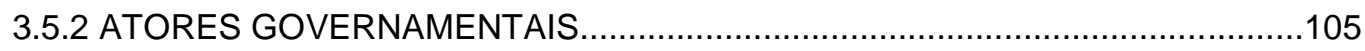

3.5.3 PERCEPÇÕES DOS COMUNITÁRIOS ..................................................110

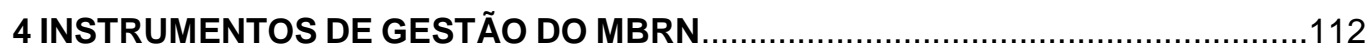

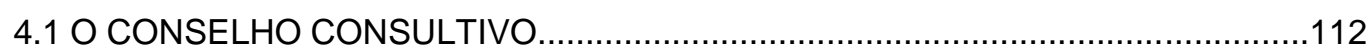

4.2 A FORMAÇÃO DO CONSELHO CONSULTIVO................................................113

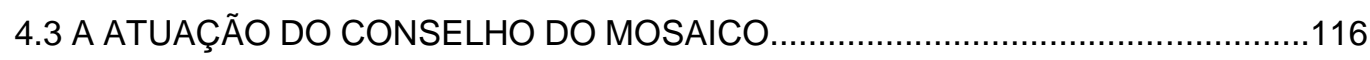

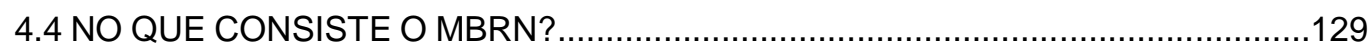

4.4.1 PERCEPÇÕES DOS ATORES GOVERNAMENTAIS E NÃO-

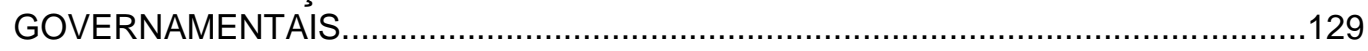

4.4.2 PERCEPÇÕES DOS COMUNITÁRIOS ......................................................132

CONCLUSÕES

REFERÊNCIAS

ANEXOS 


\section{Introdução}

Atualmente, o principal instrumento para a conservação da biodiversidade é o estabelecimento de áreas protegidas (DRUMMOND et al., 2010). De acordo com a definição da Internacional Union for Conservation of Nature (IUCN), as áreas protegidas correspondem a espaços geográficos com delimitação bem definida. A criação, implantação e gestão das áreas protegidas baseiam-se em instrumentos legais ou outros similares. A finalidade das áreas protegidas é conservar a natureza ao longo do tempo, preservar os serviços associados aos ecossistemas, bem como os valores culturais neles inseridos.

As áreas protegidas estão disseminadas em cerca de oitenta por cento dos países do mundo, cobrindo aproximadamente $14,6 \%$ da superfície terrestre do planeta (BENSUSAN, 2014). No Brasil, as áreas protegidas correspondem às Unidades de Conservação - UCs - estabelecidas na Lei no 9.985/2000, que criou o Sistema Nacional de Unidades de Conservação- SNUC e demais espaços especialmente protegidos como Terras Indígenas, Territórios Quilombolas, áreas de Reserva Legal e de Preservação Permanente, previstos em outros dispositivos legais, como a Lei $\mathrm{n}^{\circ}$ 12.651/2012 que estabeleceu o novo Código Florestal.

De acordo com os dados constantes no Cadastro Nacional de Unidades de Conservação- CNUC, do MMA, atualizados até a data de 27 de outubro de 2014, no Brasil, a área total coberta por UCs é de aproximadamente $1.513 .366 \mathrm{Km}^{2}$, considerando as sobreposições mapeadas. Neste cálculo, foram contabilizadas as UCs federais, estaduais e municipais e também incluídas as RPPNs. As UCs estão localizadas nos diversos biomas brasileiros, na área continental e marinha, somando um total de 1.930 unidades, se consideradas as sobreposições.

A estratégia de criação de áreas protegidas teve início no século XIX. Porém, a motivação para o estabelecimento dessas áreas, durante o século XIX, difere das motivações atuais. Na segunda metade do século XIX, as áreas protegidas eram criadas com o intuito de preservar sítios detentores de significativa beleza cênica, para preservar paisagens para as futuras gerações. A partir do século $\mathrm{XX}$, as áreas protegidas se popularizaram. Isto ocorreu em razão do avanço registrado nas taxas de extinção de espécies. As áreas protegidas passaram a representar uma resposta a esta crise de extinções (BENSUSAN, 2014; DAVENPORT \& MADHU, 2002; DRUMMOND et al., 2010). 
A ideia de proteger paisagens, ecossistemas e espécies da ação antrópica destruidora inicia-se na prática com a criação do Parque Nacional de Yellowstone, nos Estados Unidos da América, em 1872. O modelo de área protegida que Yellowstone sugeria excluía o ser humano de seu contexto, de modo que a área destinada ao Parque não poderia ser habitada ou ocupada por seres humanos. Este modelo foi adotado em diversos outros países, vigorando até os dias de hoje (BENSUSAN, 2014; DRUMMOND et al., 2010). Ainda, o modelo de áreas protegidas proposto por Yellowstone sugeria a dissociação dos espaços especialmente protegidos do restante da paisagem, transformando-os em verdadeiras ilhas de biodiversidade (MILLER, 1997).

A partir da década de 1990, ampliaram-se as discussões em torno da questão relacionada à presença de populações humanas no interior de áreas protegidas, em especial de Parque Nacionais. Isto se deve ao fato de que, na década de 1990, foi constatada a presença de populações humanas em cerca de $86 \%$ dos Parques Nacionais da América do Sul. O Quarto Congresso Mundial de Parques, realizado em Caracas, em 1992, incluiu em suas recomendações o respeito pelas populações tradicionais, rejeitando a estratégia de reassentamento dessas populações em razão do estabelecimento de áreas protegidas (BENSUSAN, 2014).

No Brasil, o ápice da mudança de paradigma com relação ao modelo de áreas protegidas ocorre durante os debates para a construção do SNUC. O Sistema, instituído oficialmente em 2000, por meio da Lei $\mathrm{n} \cong 9.985$, estabeleceu o grupo de UCs de uso sustentável como resultado dos debates e negociações. Este grupo é constituído por sete categorias de UCs, as quais, na maior parte, permitem a presença de populações humanas, desde que contribuam para a conservação ambiental, por meio da exploração e do uso sustentável dos recursos naturais presentes na UC (DRUMMOND et al., 2010). De acordo com o Fundo Mundial para a Natureza (WWF), ONG conservacionista, as Reservas Particulares do Patrimônio Natural- RPPNs estão entre as UCs de uso sustentável, porém somente permitem a realização de atividades recreativas, turísticas e de educação ambiental dentro de seus limites, diferindo em parte das demais UCs do grupo de uso sustentável.

Além disso, o modelo de áreas protegidas representado e recomendado pelo Parque de Yellowstone demonstrou-se insuficiente, pois tais áreas protegidas tornaramse verdadeiras ilhas de biodiversidade, dissociadas do restante da paisagem e pressionadas pelas atividades antrópicas desenvolvidas no entorno. Buscando solucionar este problema, na década de 1970, Kenton Miller desenvolveu o conceito de Gestão Biorregional (ARRUDA, 2006). 
Conforme as recomendações da Gestão Biorregional, para tornar a conservação ambiental eficiente, devem ser expandidas as escalas geográficas dos programas, através da incorporação de ecossistemas inteiros que estejam integrados às diversas atividades que são desenvolvidas tanto no interior como no entorno das áreas protegidas. O modelo desenvolvido por Miller também propunha que a gestão das áreas protegidas fosse realizada de forma compartilhada entre as diversas instituições e indivíduos atuantes na região de seu estabelecimento (ARRUDA, 2006).

$\mathrm{Na}$ ocasião da Conferência das Nações Unidas sobre Meio Ambiente e Desenvolvimento - CNUMAD, realizada na cidade do Rio de Janeiro, em 1992, foi aberta para assinatura a Convenção sobre Diversidade Biológica - CDB. A CDB é um acordo internacional multilateral que tem como objetivos principais a conservação da biodiversidade, o uso sustentável dos recursos naturais e a repartição justa e equitativa proveniente da exploração dos recursos genéticos. O Brasil, considerado país megabiodiverso, foi o primeiro signatário da CDB (INOUÊ, 2007).

Em suas recomendações para a gestão de áreas protegidas, a CDB guiou-se pelas ideias da Gestão Biorregional lançadas por Miller, adotando como princípio a abordagem ecossistêmica. Conforme esta abordagem, as áreas protegidas devem abarcar espaços amplos, constituídos por um ou mais ecossistemas, definidos de acordo com suas características topográficas, cobertura vegetal, socioeconomia, cultura e história local, instituições e indivíduos atuantes (ARRUDA, 2006).

Em 2000, a partir da criação da Lei do SNUC, o Brasil passa a adotar oficialmente modelos de gestão de áreas protegidas inspirados no modelo de Gestão Biorregional, visando também atender às recomendações estabelecidas da CDB. O SNUC inovou ao recomendar instrumentos inspirados na Gestão Biorregional, como por exemplo, as Reservas da Biosfera e os Mosaicos de Áreas Protegidas. Conforme o normativo, a Reserva da Biosfera corresponde a um modelo de gestão de áreas protegidas adotado internacionalmente, no qual a gestão é realizada de forma integrada e participativa, visando o uso sustentável dos recursos naturais. São objetivos da Reserva da Biosfera a preservação da diversidade biológica, o desenvolvimento de atividades de pesquisa, o monitoramento e a educação ambiental, o desenvolvimento sustentável e a melhoria da qualidade de vida das populações.

Os Mosaicos de Áreas Protegidas são definidos no Artigo 26 da Lei do SNUC, da seguinte forma: 
Quando existir um conjunto de unidades de conservação de categorias diferentes ou não, próximas, justapostas ou sobrepostas, e outras áreas protegidas públicas ou privadas, constituindo um mosaico, a gestão do conjunto deverá ser feita de forma integrada e participativa, considerando-se os seus distintos objetivos de conservação, de forma a compatibilizar a presença da biodiversidade, a valorização da sociodiversidade e o desenvolvimento sustentável no contexto regional (BRASIL, 2000).

A presente pesquisa visou compreender o contexto de um dos mais importantes mosaicos do Brasil, a saber o Mosaico do Baixo Rio Negro - MBRN. A importância deste mosaico deve-se à dimensão e status da área que visa proteger, pois o mosaico cobre cerca de sete milhões de hectares de área de floresta amazônica ainda bem preservada. Trata-se de compreender como o MBRN vem contribuindo para a conservação da biodiversidade.

Para isto, foram realizadas consultas à bibliografia pertinente, incluindo livros, artigos científicos, ensaios, cadernos, dissertações e teses, além de mapas. As fontes primárias que foram consultadas correspondem a documentos do governo, de organizações não governamentais - ONGs - e de organizações da sociedade civil que estejam envolvidas na gestão do mosaico. Deste modo, foram feitas consultas a atas, relatórios de reuniões, a editais, aos normativos pertinentes à legislação ambiental brasileira, aos planos de ação, resumos de oficinas, projetos e propostas de projetos, diagnósticos, memórias, boletins, a apresentações realizadas em encontros e reuniões e a depoimentos. Além disso, foram realizadas entrevistas semiestruturadas com membros do Conselho Consultivo do Mosaico- CCMBRN e com demais atores envolvidos com a sua gestão. Também foram realizadas observações durante a $9^{a}$ Reunião Ordinária do Conselho, ocorrida no período de 31/07/14 a 02/08/14 em Novo Airão, Estado do Amazonas, município considerado como "o coração do mosaico".

O primeiro capítulo da presente dissertação trata da análise do histórico da política de áreas protegidas no Brasil e no mundo e sua evolução para o modelo de mosaico, trazendo uma descrição dos principais tipos de áreas protegidas estabelecidas pela legislação ambiental brasileira. Neste capítulo, são analisados conceitos que servem de base para o entendimento acerca dos mosaicos de áreas protegidas. Além disso, são analisadas as relações entre o modelo de Gestão Biorregional, proposto por Kenton Miller na década de 1970, e os mosaicos de áreas protegidas recomendados pelo SNUC; as relações entre as recomendações da CDB e a criação de mosaicos no Brasil, bem como outros instrumentos de política ambiental brasileiros inspirados no modelo de Gestão Biorregional, como os Corredores Ecológicos ou Biorregionais estabelecidos pelo Programa Corredores Ecológicos - PCE. 
Também no capítulo inicial, é descrito o cenário atual das áreas protegidas no Brasil, trazendo dados quantitativos acerca do número de UCs criadas no território nacional, bem como o quantitativo referente à área coberta por elas. Ainda neste capítulo, é analisado o salto ocorrido no quantitativo de UCs estabelecidas no território nacional a partir da década de 1990; são comparados dados quantitativos relativos às áreas protegidas estabelecidas no Brasil e no mundo; são comparados os níveis de proteção nacional proporcionados pelo instrumento das áreas protegidas para os ambientes terrestre e marinho; é analisada a cobertura do território brasileiro por áreas protegidas por bioma, evidenciando problemas de concentração e de subrepresentação; são comparados os grupos de UCs do SNUC- proteção integral e uso sustentável- quanto sua implementação; é analisada de modo crítico a predominância de categorias de UCs quanto à criação no território nacional; são esboçados os problema relativos à representatividade ecológica no que tange o sistema brasileiro de áreas protegidas, as dificuldades de gestão e governança das UCs, bem como os novos desafios das áreas protegidas que surgiram em razão do novo contexto ecológico mundial.

No segundo capítulo, é analisado o conceito de mosaico de áreas protegidas, a participação social na gestão de UCs, bem como o histórico relativo ao surgimento dos mosaicos no Brasil. Ainda neste capítulo, é traçado um panorama geral para todos os mosaicos reconhecidos no Brasil, abordando as particularidades de cada um deles, com o intuito de compreender o contexto atual dos mosaicos brasileiros. Também, é discutido o problema da fragmentação florestal e de suas relações com os mosaicos de áreas protegidas. Neste tópico, a fragmentação florestal é analisada de modo comparativo, tendo por base os Biomas Mata Atlântica e Floresta Amazônica. Esta metodologia de análise foi utilizada na pesquisa para compreender as relações entre os mosaicos da Mata Atlântica e os da Floresta Amazônica, e os processos de fragmentação florestal presentes em cada um dos biomas.

O terceiro capítulo analisa o processo de constituição e reconhecimento do MBRN, introduzindo o estudo de caso proposto pela presente pesquisa. Neste capítulo, procedeu-se à análise dos contextos de cada uma das UCs que compõem o mosaico, visando compreender as partes do todo. Foi realizado um estudo crítico acerca do histórico da região do baixo rio negro, para compreender o contexto atual da região onde insere-se o mosaico. Para ampliar a compreensão sobre o processo de criação do MBRN, buscou-se analisar o contexto da política ambiental brasileira relativo aos períodos de criação das UCs que posteriormente aderiram ao mosaico, e ao período no qual ocorreu o reconhecimento do mosaico pelo MMA, em 2010. Ainda neste capítulo, 
é descrita uma análise sobre o problema relativo à sobreposição de políticas públicas na região do baixo rio negro, o qual impacta o MBRN.

Ainda no terceiro capítulo, são descritas as percepções dos atores envolvidos na gestão do MBRN, no que se refere às motivações para a criação deste mosaico. Para isto, foram entrevistados conselheiros do mosaico e demais envolvidos na sua gestão, como por exemplo, gestores do Governo Federal e membros de ONGs. Com isto, buscou-se compreender as principais motivações que nortearam a criação do MBRN, os seus objetivos e as disposições dos atores envolvidos na sua gestão.

O quarto e último capítulo traz uma análise do processo de formação e do atual funcionamento do Conselho Consultivo do mosaico- CCMBRN, visando compreender como vem ocorrendo a gestão do MBRN. Com esta finalidade, foram realizadas entrevistas com os gestores, bem como a participação na 9a ${ }^{a}$ Reunião Ordinária do Conselho. Também neste capítulo, são analisadas as percepções dos atores envolvidos na gestão do mosaico quanto ao que consiste o MBRN. Por fim, os resultados da presente pesquisa foram descritos no tópico relativo à conclusão.

Dentre as conclusões apresentadas na presente dissertação está a constatação de que o MBRN representa um instrumento potencial para a conservação da biodiversidade e para o desenvolvimento sustentável da região do baixo rio negro. Isto porque os primeiros passos dados pelo mosaico rumo à gestão compartilhada e integrada já apresentam evidências do desenvolvimento sustentável de base conservacionista pretendido para a região.

Constatou-se também que o MBRN representa uma força política importante para garantir a conservação da biodiversidade e se constitui como um espaço de diálogo no qual é possível compartilhar os temas de gestão, bem como buscar soluções para os conflitos socioambientais. No entanto, o MBRN recebe pouco apoio do Governo Federal, carecendo de recursos financeiros e administrativos para possibilitar seu pleno funcionamento. 


\title{
CAPÍTULO 1- ÁREAS PROTEGIDAS E GESTÃO BIORREGIONAL
}

\author{
1.1- O SURGIMENTO DA POLÍTICA DE ÁREAS PROTEGIDAS, A GESTÃO \\ BIORREGIONAL E OS INSTRUMENTOS DE POLÍTICA BIORREGIONAL \\ ADOTADOS NO BRASIL
}

A International Union for Conservation of Nature (IUCN) define as áreas protegidas como espaços geográficos com delimitação bem definida, cuja criação, implantação e gestão são baseadas em instrumentos legais ou outros igualmente eficientes, sendo finalidade das áreas protegidas conservar a natureza ao longo do tempo, bem como preservar os serviços associados ao ecossistema e os valores culturais nele inseridos.

As áreas protegidas contribuem para a conservação da biodiversidade, para a valorização dos territórios das sociedades tradicionais e para o desenvolvimento sustentável em todo o mundo (CARDOSO et al., 2010). A criação e o manejo de áreas protegidas propiciam proteção aos habitats contra usos antrópicos destrutivos, conservando os ecossistemas em graus variados (PRATES \& SOUSA, 2014). Historicamente, esta estratégia disseminou-se no mundo a partir do fim da segunda metade do século XIX, firmando-se, até os dias de hoje, como o principal instrumento de proteção à natureza (DRUMMOND et al., 2010).

O surgimento dessas áreas esteve, em seu início, vinculado ao interesse pela preservação de áreas terrestres ou aquáticas detentoras de características naturais excepcionais, como beleza, grandiosidade e raridade, ou seja, priorizava-se, sobretudo, os aspectos estéticos na seleção de áreas a serem especialmente protegidas (DRUMMOND et al., 2010; DAVENPORT \& MADHU, 2002). Ao longo do tempo, novos objetivos foram sendo agregados a essas áreas. Esta dinâmica deu origem a um conjunto diversificado de categorias de áreas protegidas (DRUMMOND et al., 2010).

No Brasil, a abrangência do termo área protegida é em parte definida no Decreto no 5.758 de 13 de abril de 2006. Este Decreto instituiu o Plano Estratégico Nacional de Áreas Protegidas - PNAP. Este Plano foi desenvolvido para atender ao Programa de Trabalho sobre Áreas Protegidas da CDB. O objetivo principal do PNAP foi o estabelecimento de um sistema abrangente de áreas protegidas, que fosse representativo em termos ecológicos e integrasse as áreas terrestres e marinhas, até 2015 (PRATES \& SOUSA, 2014). 
O PNAP trouxe como um de seus princípios o reconhecimento do papel das Terras Indígenas e dos Territórios Quilombolas para a conservação da biodiversidade, considerando esses territórios como áreas protegidas complementares às UCs. Além disso, o PNAP reconhece as funções desempenhadas pelas Áreas de Proteção Ambiental - APPs e Reservas Legais- RLs, definidas no Código Florestal brasileiro, no que tange à conservação da biodiversidade. O Plano considera as APPs e RLs como áreas estratégicas para a conectividade entre fragmentos florestais e demais áreas protegidas e recomenda que ambas sejam tratadas no âmbito da abordagem ecossistêmica e no planejamento da paisagem (PRATES \& SOUSA, 2014).

A recente reformulação do Código Florestal resultou na flexibilização das APPs, lançando dúvidas sobre a real função de conectividade a ser desempenhada por essas áreas protegidas. Em seu Artigo 3ํㅡ, a Lei № 12.651/2012, que instituiu o novo Código Florestal, reconhece o papel das APPs no que tange à conservação da biodiversidade e manutenção dos serviços ecossistêmicos. Porém, por outra via, o Artigo trouxe como inovação a permissão para práticas de atividades produtivas agrícolas e aquícolas em APPs, trazendo questionamentos acerca da função de conectividade que deve ser desempenhada por elas (PRATES \& SOUSA, 2014). O PNAP, direta ou indiretamente, assume como áreas protegidas: UCs, Terras Indígenas, Territórios Quilombolas, APPs e RLs, abrindo o leque conceitual.

As UCs são áreas protegidas definidas na Lei do Sistema Nacional de Unidades de Conservação - SNUC, Lei ํㅜ 9.985 de 2000 . Conforme o Artigo $2^{\circ}$ desta lei:

\footnotetext{
Uma UC corresponde a um espaço territorial e seus recursos ambientais, incluindo as águas jurisdicionais, com características naturais relevantes, legalmente instituído pelo Poder Público, com objetivos de conservação e limites definidos, sob regime especial de administração, ao qual se aplicam garantias adequadas de proteção (BRASIL, 2000).
}

A Lei do SNUC instituiu doze categorias de UCs, que são divididas em dois grupos específicos de proteção: o grupo de proteção integral e o grupo de uso sustentável. Segundo a Lei do SNUC, proteção integral significa a manutenção dos ecossistemas livres de alterações causadas pela interferência humana, sendo admitido apenas o uso indireto dos seus atributos naturais, e uso sustentável refere-se à exploração do ambiente de maneira a garantir a perenidade dos recursos ambientais renováveis e dos processos ecológicos, 
mantendo a biodiversidade e os demais atributos ecológicos, de forma socialmente justa e economicamente viável.

Conforme o Artigo 8 da Lei do SNUC, o grupo de UCs de proteção integral é composto pelas seguintes categorias: Estação Ecológica - ESEC, Reserva BiológicaREBIO, Parque Nacional - PARNA (quando criado por estado ou município denominase Parque Estadual e Parque Natural Municipal, respectivamente), Monumento Natural - MN e Refúgio de Vida Silvestre - RVS. O grupo de uso sustentável está definido no Artigo $14^{\circ}$, sendo composto pelas seguintes categorias de UCs: Área de Proteção Ambiental - APA, Área de Relevante Interesse Ecológico - ARIE, Floresta Nacional FLONA (quando criada por estado ou município é denominada Floresta Estadual ou Municipal, respectivamente), Reserva Extrativista - RESEX, Reserva de Fauna REFAU, Reserva de Desenvolvimento Sustentável - RDS, e Reserva Particular do Patrimônio Natural - RPPN.

O Brasil conta ainda com as áreas protegidas que são definidas na Lei $\mathrm{n}^{\circ}$ 12.651/2012, que instituiu o novo Código Florestal. De acordo com esta lei, são estabelecidas como áreas protegidas as Áreas de Preservação Permanente - APPs e as Reservas Legais - RLs. O Artigo 3ํ do novo Código Florestal descreve a APP como uma determinada área protegida, coberta ou não por vegetação nativa, com a função ambiental de preservar os recursos hídricos, a paisagem, a estabilidade geológica e a biodiversidade, bem como facilitar o fluxo gênico de fauna e flora, proteger o solo e assegurar o bem-estar das populações humanas.

Conforme o novo Código Florestal, as APPs correspondem às matas ciliares, às faixas localizadas no entorno de lagos e lagoas naturais, às áreas localizadas em torno de reservatórios de águas artificiais decorrentes de represamento ou barramento, às áreas no entorno das nascentes e dos olhos d'água perenes, às encostas ou partes destas que detenham declividade superior a $45^{\circ}$, às restingas, aos manguezais, às bordas de tabuleiros e chapadas até a linha de ruptura do relevo, aos topos de morros, montanhas, montes e serras com altura mínima de cem metros e inclinação média maior que $25^{\circ}$, às áreas de altitude superior a 1.800 metros e às faixas marginais das veredas com largura mínima de cinquenta metros. No entanto, conforme já citado, com a reformulação do Código Florestal, a função de conservação da biodiversidade e manutenção dos serviços ecossistêmicos prestada pelas APPs passou a ser questionada, uma vez que o novo normativo trouxe a permissão para a prática de atividades produtivas nos espaços destinados às APPs. 
A Reserva Legal - RL - também corresponde a um tipo de área protegida estabelecida no Código Florestal. De acordo com o Artigo 12 deste normativo, a Reserva Legal corresponde a uma área com cobertura de vegetação nativa, localizada no interior de uma propriedade ou posse rural, destinada a regime especial de proteção. A delimitação da $R L$ deve observar os percentuais mínimos de área a ser destinada, os quais são estabelecidos no Código Florestal da seguinte forma: para os imóveis localizados na Amazônia Legal, a RL deve corresponder a 80\% do imóvel localizado em áreas de floresta; $35 \%$ do imóvel situado em áreas de cerrado e $20 \%$ do imóvel localizado em áreas de campos gerais. Nos imóveis localizados nas demais regiões do país, a $R L$ deverá cobrir $20 \%$ da área total. A função da Reserva Legal é assegurar o uso sustentável dos recursos naturais nos imóveis rurais, auxiliar na conservação e reabilitação dos processos ecológicos, promover a conservação da biodiversidade, bem como abrigar e proteger a fauna silvestre e a flora nativa.

O termo área protegida, portanto, é mais amplo que o termo unidade de conservação, pois abrange um número maior de categorias, incluindo as APPs, RLs, terras indígenas e territórios quilombolas, além das UCs. Estas correspondem estritamente às áreas protegidas definidas na Lei do SNUC. Conforme já mencionado, a estratégia de criação de áreas protegidas foi impulsionada no mundo a partir da segunda metade do século XIX, tendo por objetivo, em seus primórdios, a preservação de áreas detentoras de características excepcionais como beleza cênica e raridade. $A$ criação, em 1872, do Parque Nacional de Yellowstone, nos Estados Unidos da América, refere-se a um marco da moderna política ambiental de criação de áreas protegidas. Desde então, os parques multiplicaram-se pelo mundo e, atualmente, esta categoria é o tipo mais disseminado e tradicional de espaço natural protegido (DRUMMOND et al., 2010).

No Brasil, as primeiras propostas de criação de parques nacionais foram sugeridas pelo engenheiro André Rebouças, em 1876. A ideia era criar dois parques nacionais em dois locais, sendo estes, a Ilha do Bananal e Sete Quedas. No entanto, esses parques somente foram criados muitos anos depois. Na llha do Bananal, foi criado, em 1959, o Parque Nacional do Araguaia, e no Paraná, em 1961, foi criado o Parque Nacional de Sete Quedas. Porém, em 1980, deixou de ser Parque Nacional para ceder lugar ao lago da barragem da Usina Hidrelétrica de Itaipu (DRUMMOND et al., 2010). 
O Parque Nacional de Itatiaia, criado em 1937, foi o primeiro da categoria implantado no Brasil, seguido de Iguaçu e Serra dos Órgãos, ambos criados em 1939. Porém, outras categorias de áreas protegidas foram criadas no Brasil anteriormente a 1937. Nos fins do século XIX e início do século XX, foram criadas no Brasil duas Estações Biológicas. Ambas as áreas eram destinadas à visitação e à pesquisa científica: a Estação Biológica do Alto da Serra, localizada na Serra do Mar, e a Estação Biológica de Itatiaia, criada na região onde posteriormente seria implantado o Parque Nacional de Itatiaia (DRUMMOND, et al., 2010).

Em 1934, foi criada no Brasil outra categoria de área protegida: a Estação Florestal Experimental. Seu caráter era experimental e seu objetivo de criação era o controle do uso da madeira. Deste modo, a Estação Florestal Experimental é precursora das UCs de uso sustentável elencadas na Lei do SNUC, especificamente das Florestas Nacionais- FLONAS, pois em 2001, por meio da Portaria ํㅡㄴ 246, o Ministério do Meio Ambiente - MMA - alterou sua categoria para a de Floresta Nacional (DRUMMOND et al., 2010).

O Código Florestal de 1934, instituído pelo Decreto nº 23.793, estabeleceu outras categorias de áreas protegidas. Este normativo classificou as florestas em quatro tipos: protetoras e remanescentes (sob regime de preservação permanente) e modelos e produtivas (sob regime de uso sustentável). As florestas protetoras podem ser consideradas antecedentes das APPs, áreas protegidas definidas no novo Código Florestal. As florestas modelo correspondiam a florestas plantadas e manejadas para fins comerciais e podem ser consideradas precursoras das FLONAs, UCs de uso sustentável definidas na Lei do SNUC (DRUMMOND et al., 2010). Torna-se evidente o fato de que anteriormente à sistematização do SNUC, já era prática no Brasil a criação de diversas categorias de áreas protegidas com objetivos variados, tendo por base a proteção à natureza.

O Código Florestal instituído em 1965 inovou ao estabelecer a distinção entre as áreas protegidas de uso direto e as de uso indireto. As áreas protegidas de uso direto permitiam a exploração dos recursos naturais dentro de seus limites geográficos, enquanto que as áreas protegidas sob regime de uso indireto não permitiam tal uso. Em 1981, por meio da Lei no 6.902, foram criadas no Brasil novas categorias de áreas protegidas: as Áreas de Proteção Ambiental- APAs - e as Estações Ecológicas- ESECs. Em 1985, o Decreto № 89.336, de 31 de janeiro de 1984, estabeleceu mais duas novas 
categorias de áreas protegidas: as Reservas Ecológicas e as Áreas de Relevante Interesse Ecológico - ARIEs (DRUMMOND et al., 2010).

As Reservas Extrativistas - RESEX - surgiram no Brasil em 1987. Esta categoria de UC é resultado da luta dos seringueiros pela permanência na terra e pela preservação de sua identidade sociocultural. Durante a década de 1980, o Governo Federal empenhou-se em implementar nas áreas ocupadas pelos seringueiros na Amazônia projetos desenvolvimentistas que envolviam formas de uso dos recursos naturais incompatíveis com o modo de vida dessas populações, bem como com a conservação da natureza. Eram projetos voltados para as atividades de mineração e para a agropecuária. Diversos conflitos entre seringueiros, pecuaristas e empresários do ramo da mineração ocorreram na região. Como resultado da luta dos seringueiros pela permanência em suas terras e pela manutenção de seu modo de vida, o Instituto Nacional de Colonização e Reforma Agrária- INCRA, por meio da Portaria ํㅡ 627, de 30 de julho de 1987, instituiu o Projeto de Assentamento Extrativista - PAE, que pode ser considerado o precursor das RESEXs elencadas na Lei do SNUC (BENSUSAN, 2014; IBAMA, 2014).

As Reservas Particulares do Patrimônio Natural - RPPNs - foram criadas em 1996, por meio do Decreto № 1.992. Elas descendem dos Santuários de Fauna e Flora estabelecidos no Código Florestal de 1965. Sua função como UC é de caráter complementar para o ordenamento territorial voltado para a conservação ambiental, visto que as RPPNs, em conjunto com as APPs e RLs, exercem papel central na formação das zonas de amortecimento ${ }^{1}$ das UCs, bem como no estabelecimento de Corredores Ecológicos ${ }^{2}$ que possam servir de ligação entre fragmentos florestais ${ }^{3}$ (ALGER \& LIMA, 2003).

A Reserva de Desenvolvimento Sustentável- RDS também surgiu no Brasil em 1996. Criada por decreto do governo amazonense, a RDS Mamirauá foi a primeira a ser instituída no Brasil. A criação da RDS Mamirauá integra a ideia do Projeto Mamirauá, concebido desde meados da década de 1970 até os anos 1990. Um fator importante na criação deste novo modelo de UC diz respeito ao papel desempenhado pelos

${ }^{1}$ Zonas de amortecimento: entorno de uma UC.

2 Corredor Ecológico: porções de ecossistemas naturais ou seminaturais, ligando UCs, que possibilitam entre elas o fluxo de genes e o movimento da biota, facilitando a dispersão de espécies e recolonização de áreas degradadas, bem como a manutenção de populações que demandam para a sua sobrevivência áreas com extensão maior do que aquela das UCs (Lei do SNUC, Artigo 2º, XIX).

3 Fragmentação Florestal: processo pelo qual um habitat contínuo é dividido em manchas ou fragmentos de áreas isoladas (Brant et al., 2003). 
pesquisadores que atuavam no local, bem como a existência de uma rede transnacional de biólogos da conservação. A RDS Mamirauá foi pioneira na proposta de conciliação entre conservação da biodiversidade e desenvolvimento sustentável no Brasil, pois a RDS representa um modelo de gestão de UC que não requer a retirada das populações de dentro das áreas a serem protegidas (INOUÊ, 2007; IDSM, 2014).

O Brasil chegou à década de 1990 com uma diversidade considerável de categorias de áreas protegidas. A Lei do SNUC visou a sistematização das diversas categorias de UCs. Ela tem como objetivo principal estabelecer critérios e normas para a criação, implantação e gestão das UCs. Além disso, ela buscou a conformidade com as recomendações estabelecidas na CDB. (ARRUDA, 2006; INOUÊ, 2007; DRUMMOND et al., 2010).

A CDB, em seu Artigo $2 \stackrel{\circ}{\circ}$, define biodiversidade como a variabilidade de organismos vivos de todas as origens, compreendendo, dentre outros, os ecossistemas terrestres, marinhos e outros ecossistemas aquáticos e complexos ecológicos de que fazem parte, compreendendo ainda a diversidade dentro de espécies, entre espécies e de ecossistemas. Desta forma, o conceito de biodiversidade abarca três diferentes níveis de diversidade da vida no planeta, sendo estes: o que se refere à diversidade genética dentro de uma mesma espécie; a diversidade entre as diferentes espécies e a diversidade entre os ecossistemas (BRANT et al., 2003).

A CDB é o mais importante instrumento jurídico internacional de proteção da biodiversidade. Seu papel é o de orientar as ações de conservação dos países signatários. A principal estratégia de conservação recomendada pela CDB corresponde às áreas protegidas. A CDB elabora Planos Estratégicos, para períodos determinados, visando minimizar o processo global de perda de biodiversidade, bem como assegurar a justa repartição dos benefícios oriundos da exploração dos recursos naturais. Desta forma, a CDB instituiu o Plano Estratégico 2002-2010. No entanto, conforme os resultados coletados a partir das avaliações conduzidas para aferir a efetividade do Plano, não houve um bom desempenho, ou seja, não foi constatada uma redução significativa na taxa global de perda de biodiversidade em razão do Plano Estratégico (PRATES \& SOUSA, 2014).

O Brasil, de 2003 a 2008, avançou bastante na política de criação de UCs e foi responsável pela criação de $74 \%$ das áreas protegidas do planeta durante este período. O Bioma Amazônia foi priorizado nesta política de criação e implementação de UCs, 
pois elas representavam uma forma de contenção dos altos índices de desmatamento registrados. Diante do insucesso do Plano Estratégico 2002-2010, a CDB, durante a 10 á Conferência das Partes- COP10, realizada em 2010, na Província de Aichi, no Japão, estabeleceu um novo Plano Estratégico para o período de 2011-2010. Neste Plano, foram estabelecidas as vinte metas, denominadas de Metas de Aichi, para serem alcançadas até 2020 (PRATES \& SOUSA, 2014).

Dentre as Metas de Aichi, a Meta 11 corresponde ao estabelecimento de compromissos para as áreas protegidas. De acordo com ela, os países signatários da CDB devem empenhar-se na criação de novas áreas protegidas, bem como promover a efetividade de gestão, a representatividade ecológica e a governança equitativa das áreas protegidas, estabelecendo a conectividade entre elas. Conforme esta meta, até 2020 , ao menos $17 \%$ das áreas terrestres e de águas continentais, e ao menos $10 \%$ das áreas costeiras devem ser áreas protegidas, e deverão ser pensadas e planejadas de forma integrada às paisagens mais amplas das quais fazem parte (PRATES \& SOUSA, 2014).

Desde o início de sua implementação, em 1993, a CDB segue os novos paradigmas da conservação que surgiram a partir da década de 1970. Esses novos paradigmas encontram suas bases no Biorregionalismo, escola de origem escocesa que surgiu a partir da iniciativa de grupos humanos que habitavam vales e zonas costeiras. Tais grupos passaram a optar pela cooperação no manejo de suas áreas, de modo a assegurar o fornecimento dos recursos naturais a longo prazo (MILLER,1997). O Biorregionalismo propôs a gestão participativa como modo de garantir a oferta dos recursos naturais às gerações futuras.

Inspirado no Biorregionalismo, Kenton Miller, formulou o conceito de Gestão Biorregional. O propósito era o de solucionar o problema da gestão de áreas protegidas no que diz respeito ao isolamento, pois a estratégia de conservação da natureza baseada na criação de áreas protegidas, desde os seus primórdios, priorizou a implantação de áreas isoladas umas das outras, desintegradas de um contexto mais amplo que englobasse o ecossistema como um todo, em seus diversos aspectos: biológicos, econômicos, sociais e culturais (ARRUDA, 2006).

Para Miller (1997), as áreas protegidas corriam o perigo de se transformarem em verdadeiras ilhas de diversidade biológica, pressionadas pelas atividades praticadas em seus entornos, incompatíveis com os propósitos de conservação destas. Visando 
solucionar este problema, Miller recomendou a expansão das escalas geográficas dos programas de conservação. Para isto, sugeriu que os programas de conservação incorporassem ecossistemas inteiros, de forma integrada às atividades, instituições e indivíduos que atuam e habitam no interior e no entorno das áreas a serem conservadas.

A CDB aprofundou as bases para o enfoque na gestão integrada de ecossistemas ao adotar como princípio guia, a partir da COP V, realizada em Nairóbi no Quênia, em 2000, a abordagem ecossistêmica. Os principais conceitos empregados na abordagem ecossistêmica são as noções de Biorregião, Ecorregião e Gestão Biorregional. A Biorregião é conceituada como um espaço geográfico constituído por um ou mais ecossistemas, definidos por suas características topográficas, cobertura vegetal, socioeconomia, cultura e história local, governo e comunidades científicas atuantes. A Ecorregião é definida como um conjunto de comunidades naturais, geograficamente distintas, que compartilham a maioria das espécies, dinâmicas e processo ecológicos, sendo fundamentais as interações ecológicas para a sobrevivência dos indivíduos a longo prazo (ARRUDA, 2006).

A Gestão Biorregional pode ser definida como uma estratégia de conservação da biodiversidade que parte de uma concepção mais ampla ao incorporar ecossistemas inteiros. São objetivos da Gestão Biorregional o uso sustentável dos recursos naturais e a repartição equitativa das riquezas geradas por esses recursos para as presentes e futuras gerações. São características da Gestão Biorregional a aplicação de programas de conservação da biodiversidade em áreas extensas, o envolvimento integral dos atores e grupos sociais que atuam na área e em seu entorno, cooperação institucional, geração e troca de informações, uso do conhecimento popular e científico e a garantia de ter asseguradas a capacidade técnica e financeira para a gestão da área protegida (ARRUDA, 2006).

A abordagem ecossistêmica recomenda que a gestão das áreas protegidas guiese pelos princípios da gestão participativa e integrada, ao recomendar o envolvimento dos diversos atores sociais, cooperação interinstitucional e integração do entorno nos objetivos de conservação, sugerindo a incorporação de áreas mais amplas nos programas de conservação da biodiversidade (REMAP, 2014). Em 2010, durante a COP10, realizada em Aichi, no Japão, a CDB reforçou as suas diretrizes no que se refere à política de áreas protegidas. Durante a Conferência, foi oficializado o novo Plano Estratégico da Convenção, elaborado para subsidiar as ações de redução de perda de biodiversidade dos países signatários. Conforme a Meta 11 do Plano 
Estratégico, os países signatários deverão ampliar seus sistemas de áreas protegidas, considerando a gestão equitativa e a integração das áreas protegidas com os espaços do entorno, inserindo-as numa paisagem mais ampla (PRATES \& SOUSA, 2014).

O Brasil, país signatário da CDB, adota políticas ambientais que se orientam por uma perspectiva sistêmica. A Lei do SNUC, em vigor desde o ano 2000, incluiu em seu texto instrumentos de política ambiental, voltados para a gestão integrada de áreas protegidas, e destas com os seus entornos, tais como a Reserva da Biosfera e o Mosaico de Áreas Protegidas. Além desses instrumentos, o Brasil também dispõe dos Corredores Biorregionais, que não estão na Lei do SNUC. Os três instrumentos incorporam princípios elaborados por Kenton Miller (1997) ao forjar o conceito de Gestão Biorregional.

As Reservas da Biosfera são áreas destinadas para a conservação e para o desenvolvimento sustentável, reconhecidas pelo Programa Homem e Biosfera da UNESCO. Este Programa foi pioneiro em contestar a separação entre ser humano e natureza, em contextos de gestão de áreas protegidas. Sua gênese tem origem na Conferência sobre a Biosfera, realizada pela UNESCO em 1968, em Paris. O Programa O Homem e a Biosfera - MaB - foi lançado em 1971, apresentando como proposta inovadora a gestão integrada dos ecossistemas.

A Reserva da Biosfera surgiu na política ambiental brasileira em 1974 e, atualmente, está sistematizada na Lei do SNUC (CARDOSO et al., 2010). De acordo com o SNUC, a Reserva da Biosfera é um modelo adotado internacionalmente, de gestão integrada, participativa e sustentável dos recursos naturais, que tem como objetivos básicos a preservação da diversidade biológica, o desenvolvimento de atividades de pesquisa, o monitoramento ambiental, a educação ambiental, o desenvolvimento sustentável e a melhoria da qualidade de vida das populações.

Conforme o MMA, a Reserva da Biosfera tem por objetivo a construção de relações positivas entre o ser humano e a natureza. Em outras palavras, este modelo de gestão de áreas protegidas visa à implementação de projetos que busquem otimizar a convivência entre ser humano e natureza por meio de projetos capazes de promover a preservação dos ambientes significativos, a incorporação das áreas vizinhas e o uso sustentável dos recursos naturais. A Reserva da Biosfera deve abranger um conjunto representativo de diversos ecossistemas, a sua área deve ser importante para a 
conservação da biodiversidade e ela poderá localizar-se em ambientes terrestres ou marinhos.

No entendimento da instituição, a Reserva da Biosfera é um centro de monitoramento, informação, pesquisa e educação ambiental. Ela é gerida de forma integrada, ou seja, por meio do trabalho conjunto de instituições governamentais e não governamentais, bem como de centros de pesquisa. As Reservas da Biosfera fazem parte de uma rede mundial que visa a conservação da biodiversidade e o desenvolvimento sustentável em âmbito internacional.

No Brasil, a primeira Reserva da Biosfera foi criada em 1992 e denominou-se Reserva da Biosfera da Mata Atlântica. O objetivo principal foi o de proteger os remanescentes deste bioma já bastante degradado. Atualmente, existem sete Reservas da Biosfera implantadas no Brasil: a Reserva da Biosfera da Mata Atlântica, a do Cinturão Verde de São Paulo, a do Cerrado, a do Pantanal, a da Caatinga, a da Amazônia Central e a da Serra do Espinhaço (MMA, 2014).

Os Corredores Biorregionais também fazem parte do conjunto de instrumentos da política ambiental brasileira que se baseiam no conceito de Gestão Biorregional desenvolvido por Kenton Miller. Propostos ao Ministério do Meio Ambiente - MMA - em 1992 por José Márcio Ayres, os Corredores da Biodiversidade são grandes áreas que contém ecossistemas florestais, biologicamente prioritários para a conservação da diversidade biológica na Amazônia e na Mata Atlântica, compostos por conjuntos de UCs, terras indígenas e áreas de interstício, de modo a prevenir ou reduzir a fragmentação florestal e permitir a conectividade entre áreas protegidas (MMA, 2014).

As áreas de interstício incluem as áreas de preservação permanente - APPs, as reservas legais - RLs e demais áreas conservadas destinadas à preservação, manejo sustentável, restauração ambiental e demais formas de uso do ecossistema que sejam compatíveis com os objetivos de conservação da biodiversidade. Em outras palavras, os Corredores Biorregionais são grandes polígonos contíguos de escala regional que incluem ecossistemas e espécies prioritárias para a conservação de determinado bioma e onde diversas áreas protegidas estão conectadas entre si no interior da matriz da paisagem (GANEM, 2011).

Após dez anos de negociação, os Corredores da Biodiversidade foram sistematizados no Projeto Corredores Ecológicos - PCE. Este projeto foi desenvolvido no âmbito do Programa Piloto para a Proteção das Florestas Tropicais do Brasil- PPG- 
7 e visou a implementação de Corredores Biorregionais nos biomas da Mata Atlântica e Amazônia, prioritariamente (GANEM, 2011). O Corredor da Biodiversidade não possui definição na legislação ambiental brasileira, sendo instrumento de gestão de áreas protegidas definido apenas no PCE. No entanto, os Corredores da Biodiversidade são unidades de planejamento regional que favorecem a conectividade entre os fragmentos florestais, de modo a facilitar o fluxo gênico entre populações de espécies e, consequentemente, aumentar as chances de sobrevivência no longo prazo das comunidades biológicas (GANEM, 2011).

Na implantação dos Corredores Biorregionais, além da definição das espécies e unidades da paisagem prioritárias para as ações de conservação, há a busca pelo engajamento de instituições que influenciam nas ações de conservação. Trata-se de uma estratégia de conservação que requer o envolvimento das diversas esferas de governo e dos diversos atores sociais capazes de impactar as ações de conservação, tais como comunidades locais, organizações não governamentais e proprietários de terras (GANEM, 2011). Os Corredores Biorregionais são, portanto, instrumentos de conservação da biodiversidade orientados pela gestão integrada e participativa, estando em harmonia com os princípios da Gestão Biorregional.

Os Corredores Biorregionais diferem dos Corredores Ecológicos tratados na Lei do SNUC. Os últimos são definidos no Artigo 2ํำ desta lei como porções de ecossistemas naturais ou seminaturais que ligam UCs, possibilitando entre elas o fluxo de genes e o movimento da biota, bem como facilitando a dispersão de espécies e a recolonização de áreas degradadas e auxiliando na manutenção de populações que demandam para sua sobrevivência áreas com extensão maior do que aquelas das UCs. Deste modo, os Corredores Ecológicos definidos na Lei do SNUC cumprem a função estrita de ligar UCs, ocorrendo na definição a exclusão das demais áreas protegidas. Além disso, conforme o normativo em questão, a função dos Corredores Ecológicos é exclusivamente biológica, pois eles correspondem a faixas de ecossistemas que visam favorecer o fluxo genético das espécies e a sobrevivência das mesmas por meio da oferta de áreas com dimensões adequadas à manutenção de suas populações.

Os Corredores Ecológicos recomendados na Lei do SNUC não se efetivaram no Brasil. Atualmente, existem apenas dois Corredores Ecológicos reconhecidos pelo MMA, sendo estes o Corredor Capivara-Confusões e o Corredor Ecológico da Caatinga. Apesar de reconhecidos em 2005 e 2006, respectivamente, ambos os Corredores ainda 
não foram implementados. Esta realidade evidencia os entraves do Brasil com relação ao atendimento às recomendações da $\mathrm{CDB}$, no que diz respeito à implementação da política de áreas protegidas, pois dentre as diretrizes da CDB aparece a conectividade entre elas (PRATES \& SOUSA, 2014).

Assim, para que o Brasil atenda à CDB nas recomendações para o estabelecimento de áreas protegidas, o instrumento relativo ao corredor ecológico deve ser melhor explorado no planejamento da paisagem. Além do Corredor Ecológico, o instrumento do mosaico de áreas protegidas, previsto no Artigo 26 da Lei do SNUC, oferece oportunidades para o aumento da conectividade entre as UCs. Isto porque o mosaico consiste num instrumento de gestão de áreas protegidas que visa propiciar a gestão integrada e participativa de um conjunto de UCs e demais áreas protegidas, possibilitando uma visão de conjunto (PRATES \& SOUSA, 2014).

O novo Código Florestal trouxe como inovação o instrumento referente ao Cadastro Ambiental Rural - CAR, definido no Artigo 29 desta lei como:

Registro público eletrônico de âmbito nacional, obrigatório para todos os imóveis rurais, com a finalidade de integrar as informações ambientais das propriedades e posses rurais, compondo uma base de dados para controle e monitoramento, planejamento ambiental e econômico e combate ao desmatamento (BRASIL, 2012).

Ainda conforme o Artigo 29 do novo Código Florestal, o CAR foi criado no âmbito do Sistema Nacional de Informações sobre Meio Ambiente - SISNIMA - e a inscrição dos imóveis rurais no CAR deverá ser realizada, preferencialmente, pelos órgãos ambientais estaduais e municipais. A função do CAR é mapear todos os imóveis rurais existentes no território nacional, promovendo paralelamente a regularização ambiental desses imóveis, a partir das delimitações obrigatórias das APPs e RLs, bem como da recuperação de áreas degradadas.

Com o mapeamento das posses e propriedades rurais, que será realizado no âmbito do CAR, será possível identificar as lacunas de conectividade existentes em razão do não cumprimento da legislação ambiental por parte dos proprietários rurais e posseiros. Em outras palavras, tornar-se-á possível verificar se na área do imóvel foram delimitadas legalmente as APPs e RLs, conforme exigido pelo Código Florestal. Este mecanismo fortalece a competência do Poder Público no que diz respeito à cobrança pela regularização ambiental dos imóveis rurais. A partir dessas ações, busca-se 
proteger a biodiversidade e os serviços ecossistêmicos, bem como promover a conectividade entre as áreas protegidas para a conformação de uma paisagem mais ampla com objetivos de conservação, que inclua o entorno das áreas protegidas. Isto porque as atividades desenvolvidas nos arredores das áreas protegidas causam impactos em seus interiores, influenciando o desempenho das áreas protegidas no que tange à conservação da biodiversidade e manutenção dos serviços ecológicos (PRATES \& SOUSA, 2014).

\section{2- O CENÁRIO ATUAL DAS ÁREAS PROTEGIDAS NO BRASIL}

O número de UCs e a área coberta por elas, no Brasil, cresceram de maneira acelerada durante as décadas de 1980, 1990 e 2000 (DRUMMOND et al., 2010). Só nos anos 2000, a área coberta por UCs no Brasil registrou um aumento de mais de 100\% nos níveis federal, estadual e municipal (PRATES \& SOUSA, 2014). Zimmerer (2011) entende que este salto no quantitativo de área coberta por UCs no Brasil ocorreu em resposta às pressões de movimentos ambientalistas e sociais, bem como em razão da ratificação pelo Brasil de acordos internacionais multilaterais, como a CDB, que demandam medidas concretas garantidoras da proteção à natureza.

Prates e Sousa (2014) relacionam o crescimento significativo na área coberta por UCs no Brasil, ocorrido no período de 2003 a 2008, com as tentativas de respostas visando consolidar instrumentos legais criados havia pouco tempo, como o SNUC, e a uma política de governo baseada no combate ao desmatamento na Amazônia. As autoras indicam algumas iniciativas governamentais implementadas no período como propulsoras do aumento da área coberta por UCs no Brasil. O Plano de Desenvolvimento Regional Sustentável para a Área de Influência da Rodovia BR-163, - Plano de Ação para a Prevenção e Controle do Desmatamento na AmazôniaPPCDAM e o Programa Áreas Protegidas da Amazônia- ARPA são exemplos dessas iniciativas.

De acordo com o Cadastro Nacional de Unidades de Conservação- CNUC, gerido pelo MMA, atualmente $16,9 \%$ do território brasileiro terrestre e $1,5 \%$ das áreas marinhas encontram-se protegidas por UCs. Se comparado ao nível global de proteção de ecossistemas terrestres, o Brasil apresenta um bom desempenho, com números expressivos de cobertura por UCs, uma vez que a área total global terrestre sob o regime 
de áreas protegidas corresponde a 14,6\%, 2,3\% inferior à área protegida por UCs no Brasil.

Tabela 1. Comparativo do Percentual das Áreas Protegidas no Brasil e no Mundo.

\begin{tabular}{|l|c|c|}
\hline Referencial & Global & Brasil \\
\hline Continental & $14,6 \%$ & $16,8 \%^{*}$ ou \\
& & $28,9 \%^{\star *}$ \\
\hline Oceanos & $2,8 \%$ & $1,5 \%$ \\
\hline Zona Econômica Exclusiva & $4,6 \%$ & - \\
\hline
\end{tabular}

Fontes: MMA- Ministério do Meio Ambiente. 2014 e FUNAI- Fundação Nacional do Índio. 2014.

${ }^{*}$ Considerando apenas as UCs cadastradas no Cadastro Nacional de Unidades de ConservaçãoCNUC, sob gestão do MMA.

${ }^{* *}$ Considerando além das UCs, as Terras Indígenas.

A análise dos dados contidos na Tabela 1 torna evidente a discrepância nos níveis de proteção por meio de áreas protegidas entre os ecossistemas terrestres e marinhos. Conforme o CNUC, no Brasil, a área coberta por UCs terrestres é de mais de 1,5 milhão de $\mathrm{Km}^{2}$, sendo que a cobertura dos ecossistemas marinhos resume-se a um pouco mais de 50 mil $\mathrm{Km}^{2}$. A lacuna na proteção dos ecossistemas marinhos brasileiros é evidente e para que se construa um sistema de áreas protegidas representativo, há a necessidade de que se envidem maiores esforços de conservação para o mar territorial brasileiro.

Ao analisarmos os dados constantes no CNUC, tem-se que, no que diz respeito à área terrestre coberta por UCs no Brasil, ocorrem também discrepâncias na área coberta em cada bioma. Nota-se uma evidente concentração de área protegida por UCs no Bioma Amazônia e uma sub-representação dos demais biomas. Este desequilíbrio persiste mesmo quando acrescidas as Terras Indígenas na contagem da área terrestre coberta por UCs no território brasileiro, pois a maior parte das Terras Indígenas concentra-se também no Bioma Amazônia. Na tabela abaixo constam dados relativos ao total de área coberta por UCs por bioma, ilustrando a discrepância existente entres os biomas no que se refere à representação no SNUC.

Tabela 2. Unidades de Conservação por Bioma.

\begin{tabular}{|c|c|c|c|c|}
\hline Bioma & Área & Área Total Coberta & Área Total Coberta por & Total de UCs \\
& Total do & por UCs $\left(\mathrm{Km}^{2}\right)$ & $\begin{array}{c}\text { UCs, considerando } \\
\text { sobreposições }\end{array}$ & \\
& $\begin{array}{c}\text { Bioma } \\
\left(\mathrm{Km}^{2}\right)\end{array}$ & & & \\
\hline
\end{tabular}




\begin{tabular}{|c|c|c|c|c|}
\hline Amazônia & 4.196 .943 & 1.112 .326 & 1.096 .229 & 314 \\
\hline Caatinga & 844.453 & 63.259 & 63.466 & 129 \\
\hline Cerrado & 2.036 .448 & 174.446 & 168.416 & 362 \\
\hline $\begin{array}{c}\text { Mata } \\
\text { Atlântica }\end{array}$ & 1.110 .182 & 108.461 & 102.793 & 1.010 \\
\hline Pampa & 176.496 & 4.863 & 4.827 & 21 \\
\hline $\begin{array}{c}\text { Pantanal } \\
\text { Área }\end{array}$ & 150.355 & 6.954 & 6.954 & 1.860 \\
Continental & 8.514 .877 & 1.470 .309 & 1.442 .685 & 151 \\
\hline $\begin{array}{c}\text { Área } \\
\text { Marinha* }\end{array}$ & 3.555 .796 & 53.771 & 52.304 & \\
\hline
\end{tabular}

Fonte: Cadastro Nacional de Unidades de Conservação- CNUC. Ministério do Meio Ambiente. Atualização em 11/02/2014.

*A Área Marinha corresponde ao mar territorial, acrescido da Zona Econômica Exclusiva (ZEE).

Partindo de uma análise sobre os grupos de categorias do SNUC, a predominância é das UCs de uso sustentável. Esse grupo representa, atualmente, $65 \%$ da área total coberta por UCs no Brasil. No entanto, esse percentual varia conforme a esfera de poder. Por exemplo, no âmbito federal, a proporção entre as UCs de proteção integral - PI - e de uso sustentável - US - apresenta um leve desequilíbrio em favor das UCs de uso sustentável, enquanto que nos níveis estadual e municipal há uma forte predominância das unidades de uso sustentável. A tabela abaixo apresenta dados do MMA relativos aos percentuais por grupo de categoria do SNUC, por bioma.

Tabela 3. Percentuais de UCs por Grupo de Categoria, por Bioma e Percentual de Terras Indígenas- Tls.

\begin{tabular}{|l|l|l|l|l|l|l|l|}
\hline & Amazônia & Caatinga & \multicolumn{1}{|c|}{ Cerrado } & $\begin{array}{c}\text { Mata } \\
\text { Atlântica }\end{array}$ & Pampa & Pantanal & Área Marinha \\
\hline PI & $9,75 \%$ & $1,26 \%$ & $3,09 \%$ & $2,48 \%$ & $0,34 \%$ & $2,93 \%$ & $0,13 \%$ \\
\hline US & $16,37 \%$ & $6,26 \%$ & $5,18 \%$ & $6,78 \%$ & $2,39 \%$ & $1,70 \%$ & $1,34 \%$ \\
\hline TI & $22,22 \%$ & $0,33 \%$ & $4,05 \%$ & $0,53 \%$ & $0,01 \%$ & $1,77 \%$ & - \\
\hline $\begin{array}{l}\text { Tot } \\
\text { al }\end{array}$ & $48,3 \%$ & $7,8 \%$ & $12,3 \%$ & $9,8 \%$ & $2,7 \%$ & $6,4 \%$ & $1,5 \%$ \\
\hline
\end{tabular}

Fontes: Ministério do Meio Ambiente- MMA, 2014 e Fundação Nacional do Índio- FUNAI, 2014.

A categoria mais representativa no SNUC atualmente são as APAs, seguidas dos Parques. Juntas, essas unidades representam cerca de $52 \%$ de toda a área coberta por UCs no Brasil. A predominância das APAs é uma questão polêmica para o SNUC, pois esta categoria de UC vem apresentando dificuldades quanto ao controle do 
desmatamento dentro de seus limites, sendo questionada acerca da efetividade de gestão (PRATES \& SOUSA, 2014). De acordo com a Lei do SNUC, a APA corresponde a uma categoria de UC que tem por objetivos proteger a biodiversidade, disciplinar o processo de ocupação e assegurar a sustentabilidade do uso e exploração dos recursos naturais.

As APAs foram concebidas para funcionar como instrumentos de ordenamento territorial, planejamento e gestão participativa. As APAs estabelecidas em ecossistemas terrestres, por não exigirem a desapropriação de propriedades particulares em seu processo de criação, vêm predominando na implementação do SNUC. No entanto, esta preferência concedida à criação de APAs, em ambiente terrestre, sobre as demais categorias de UCs vem sendo amplamente questionada pelos ambientalistas (PRATES \& SOUSA, 2014).

Este debate vem ocorrendo porque existem consideráveis dificuldades de gestão das APAs terrestres, principalmente em razão do quantitativo de áreas privadas existentes dentro de seus limites, o que fragiliza o Poder Público, impedindo-o de concretizar medidas disciplinadoras do uso dos recursos naturais. No entanto, as APAs representam uma ótima oportunidade para a conservação e uso sustentável da diversidade biológica marinha, pois nos ambientes marinhos não existem área privadas impeditivas da atuação do Poder Público, o que confere a este a possibilidade de ordenar o uso dos recursos naturais nessas unidades, promovendo a sustentabilidade (PRATES \& SOUSA, 2014).

Outro problema relacionado com o sistema de áreas protegidas brasileiro diz respeito ao fator representatividade ecológica. Atualmente, predomina a percepção segundo a qual as áreas protegidas desempenharão melhor seus papéis na conservação da biodiversidade caso façam parte de um sistema representativo, ou seja, de um sistema que consista no maior quantitativo possível de exemplos de elementos da biodiversidade (BENSUSAN, 2014). De acordo com o Fundo Mundial para a Natureza (WWF), embora o Brasil tenha se destacado no percentual de cobertura territorial por áreas protegidas em relação ao nível global, o sistema de UCs federais brasileiro apresenta falhas no que tange à representatividade ecológica. Segundo o ICMbio, somente 50,6\% das espécies da fauna brasileira ameaçadas de extinção estão representadas em UCs federais. 
Além disso, os estudos de representatividade ecológica em áreas protegidas conduzidos no Brasil utilizam a escala do bioma. No entanto, para a obtenção de uma análise mais refinada acerca da representatividade, é recomendada a utilização de escalas mais finas, que permitam um maior aprofundamento, como as escalas do ecossistema e das espécies. No Brasil, ainda não é possível orientar as ações de conservação com base em estudos de representatividade ecológica com base em escalas que permitam um maior detalhamento. Isto porque o Brasil ainda apresenta lacunas consideráveis no que diz respeito ao mapeamento dos ecossistemas existentes em seu território. Até o momento atual, somente o bioma Mata Atlântica obteve os seus ecossistemas integralmente mapeados, o que se deu em razão da obrigatoriedade estabelecida na Lei no 11.428/2006, que dispõe sobre a utilização e proteção da vegetação nativa do Bioma Mata Atlântica (PRATES \& SOUSA, 2014).

Além do problema relativo às falhas de representatividade ecológica no sistema de áreas protegidas brasileiro, estas enfrentam graves dificuldades de gestão. Atualmente, o Brasil apresenta um passivo considerável no que diz respeito à consolidação das UCs existentes. De acordo com os resultados de Auditoria Operacional sobre governança em UCs da Amazônia, realizada em 2013 pelo Tribunal de Contas da União - TCU, apenas 4\% das unidades criadas no bioma apresentam alto grau de implementação e gestão efetiva. A desarticulação entre os atores envolvidos na gestão das UCs foi apontada como um dos problemas principais que causam entraves à gestão efetiva. A baixa implementação dos instrumentos de gestão, como os Planos de Manejo, e o passivo referente à regularização fundiária foram outros fatores apontados pela auditoria do TCU como impeditivos da gestão efetiva das UCs no bioma Amazônia (PRATES \& SOUSA, 2014).

Para as autoras, o desequilíbrio na distribuição da receita governamental e também de recursos humanos conduz à perda de efetividade na conservação da biodiversidade e a dificuldades no que tange à implementação do SNUC. De acordo com dados do MMA de 2009, no período de 2001 a 2008, a receita do Ministério revertida para o SNUC aumentou em apenas 16,35\%, enquanto que a cobertura do território nacional por UCs obteve um incremento de $78,46 \%$ no mesmo período. Além disso, o montante destinado à conservação ambiental no Brasil não ultrapassa $2 \%$ do orçamento disponibilizado às obras de infraestrutura. Estes dados são indicativos das prioridades concedidas pelo governo aos setores da economia, retratando a 
manutenção do modelo desenvolvimentista e a resistência à transição para o desenvolvimento sustentável.

Conforme a Lei do SNUC, as áreas protegidas devem ser geridas por meio da gestão equitativa, ou seja, com o envolvimento dos diversos atores nas atividades voltadas à conservação. O principal instrumento criado pelo SNUC para garantir a gestão equitativa refere-se ao Conselho da UC. Dependendo da categoria da UC, o conselho poderá ser do tipo consultivo ou deliberativo. Atualmente, das 313 UCs federais existentes, 252 possuem conselho. No entanto, apesar dos avanços obtidos com o estabelecimento dos conselhos, ainda persistem dificuldades no que se refere à gestão equitativa nas UCs. Tais problemas dizem respeito a lacunas na capacitação de gestores e conselheiros, na baixa representatividade de alguns setores atuantes, bem como na insuficiência de recursos financeiros (PRATES \& SOUSA, 2014).

Além do avanço no estabelecimento dos conselhos, outros instrumentos implementados recentemente também subsidiaram a governança nas UCs, fortalecendo a gestão equitativa. A Política Nacional de Desenvolvimento Sustentável dos Povos e Comunidades Tradicionais - PNPCT, instituída pelo Decreto 6.040/2007, criou uma comissão para garantir a implementação desta política. Com isto, fortalecese as populações tradicionais e também sua participação na gestão das áreas protegidas. Somando-se à PNPCT, foi criada a Política Nacional de Gestão Territorial e Ambiental de Terras Indígenas - PNGATI, por meio do Decreto ํㅜ 7.747/2012. O objetivo da PNGATI é garantir a proteção, recuperação, conservação e uso sustentável dos recursos naturais em territórios indígenas. A partir de suas diretrizes, a PNGATI fortalece a participação das comunidades indígenas na gestão das áreas protegidas, contribuindo, desta forma, para a promoção da gestão equitativa (PRATES \& SOUSA, 2014).

Além dos problemas relacionados com a gestão efetiva e equitativa, deficiência de recursos financeiros e humanos, representatividade ecológica e distribuição espacial, as áreas protegidas passaram a enfrentar novos dilemas. Entre eles, destaca-se o problema da mudança climática. Conforme o Painel Intergovernamental de Mudanças Climáticas - IPCC, o clima está mudando rapidamente devido à ação antrópica, sendo esta velocidade o cerne da questão climática. 
Esta rapidez em que são alteradas as condições climáticas no planeta faz surgir novos questionamentos acerca da conservação da biodiversidade. Por exemplo, atualmente, questiona-se se as espécies terão tempo suficiente para se adaptarem às novas condições climáticas. O clima influencia decisivamente os padrões globais de distribuição, produtividade, estrutura e composição da vegetação e da fauna nos ecossistemas (BENSUSAN, 2014). Recentemente, o IPCC alertou para a ocorrência de alterações no padrão de distribuição de espécies, no tamanho de populações e na composição de comunidades em razão das mudanças climáticas (IPCC, 2014).

Frente aos novos dilemas, surge a necessidade de implementar novas estratégias voltadas à conservação da biodiversidade. Uma das soluções apontadas para evitar a perda de grande parte da biodiversidade ainda neste século é o planejamento da conservação, considerando a escala da paisagem. Isto significa planejar as ações de conservação numa escala que transcenda a área protegida e comtemple toda uma região. Esta ampliação de escala é fundamental em época de acelerada mudança climática (BENSUSAN, 2014).

As áreas protegidas têm enfrentado dificuldades para deter a perda de biodiversidade. Ainda assim, representam peças necessárias para a conservação ambiental, pois sem elas, a perda de biodiversidade seria intensificada. Bensusan (2014) entende que as áreas protegidas precisam ser reinventadas, por exemplo, ampliando a escala a ser abarcada para torná-las mais efetivas. As áreas protegidas, segundo a autora, ainda são percebidas como entraves ao processo de desenvolvimento e não como oportunidade de implementação de um novo modelo de desenvolvimento baseado na sustentabilidade ambiental, econômica e social. Bensusan argumenta que a proteção da biodiversidade precisa ganhar relevância junto ao público, processo que irá promover uma mudança de mentalidade, criando uma nova percepção sobre as áreas protegida, que passarão a ser concebidas como oportunidades para a implantação de um novo modelo de desenvolvimento baseado na conservação ambiental e na equidade econômica e social. 


\section{CAPÍTULO 2- OS MOSAICOS DE ÁREAS PROTEGIDAS}

\section{1- O CONCEITO DE MOSAICO DE ÁREAS PROTEGIDAS}

Além das Reservas da Biosfera e dos Corredores Biorregionais, o Mosaico de Áreas Protegidas faz parte do rol de instrumentos de política biorregional adotados no Brasil. O modelo segue orientações semelhantes às da Gestão Biorregional, tais como: a destinação de áreas maiores para a conservação; ampla participação social; a prática da gestão integrada e a inclusão do entorno das áreas protegidas nos planos de conservação e desenvolvimento sustentável.

A ideia do Mosaico de Áreas Protegidas surgiu na década de 1990, na ocasião dos debates para a elaboração da Lei do SNUC. O termo foi formulado por Paulo Nogueira Neto. Dentro deste cenário, os mosaicos surgiram como uma proposta que visava solucionar os conflitos existentes entre a criação de UCs de proteção integral e populações locais, pois este tipo de UC requer a retirada das populações residentes de suas áreas. Assim, os mosaicos surgiram como uma nova proposta de ordenamento territorial, segundo a qual é possível conciliar a conservação da natureza e desenvolvimento das populações humanas (CARDOSO et al., 2010). Após longo período de debate, em 2000, a Lei do SNUC foi sancionada, trazendo a seguinte definição de Mosaico de Áreas Protegidas em seu Artigo 26:

Quando existir um conjunto de unidades de conservação de categorias
diferentes ou não, próximas, justapostas ou sobrepostas, e outras áreas
protegidas públicas ou privadas, constituindo um mosaico, a gestão do
conjunto deverá ser feita de forma integrada e participativa, considerando-se
os seus distintos objetivos de conservação, de forma a compatibilizar a
presença da biodiversidade, a valorização da sociodiversidade e o
desenvolvimento sustentável no contexto regional (BRASIL, 2000).

De acordo com esta definição, depreende-se que o modelo de mosaico oferece uma oportunidade para a ampla participação social e institucional na gestão de sua área, pois os mosaicos poderão ser constituídos de UCs e demais áreas protegidas de diferentes tipos e categorias, que estejam sob a gestão das variadas esferas: pública e privada; federal, estadual ou municipal.

No âmbito do Programa Áreas Protegidas da Amazônia - ARPA, o modelo proposto pelos mosaicos aparece como um instrumento para otimizar a gestão das áreas protegidas por meio da gestão conjunta. No Brasil, a implementação dos 
mosaicos está associada aos planos de desenvolvimento territorial de base conservacionista, que quer dizer que os mosaicos visam promover o desenvolvimento territorial, considerando a conservação da biodiversidade (CASES et al., 2007). No que se refere à gestão compartilhada do mosaico, o envolvimento das diferentes esferas de governo e das demais instâncias, ele representa um espaço para a prática do diálogo e para a busca de soluções para os conflitos de interesse. O mosaico de áreas protegidas permite aprimorar as práticas de conservação. Isto porque abrangem áreas mais amplas em programas de conservação, se comparados às, que são criadas e implementadas de forma individualizada e isolada do restante da paisagem. Além disso, ao abarcar áreas mais amplas, os mosaicos apresentam maior representatividade ecológica e também por isso aprimoram as ações de conservação (CARDOSO et al., 2010).

Após oito anos da criação da Lei do SNUC, ocorreu em 2008, o Seminário BrasilFrança de Mosaicos de Áreas Protegidas. Como resultado deste encontro, surgiu a Rede de Mosaicos - REMAP - a qual constitui-se num espaço destinado à conexão dos atores interessados nos mosaicos, sendo uma iniciativa de fomento à gestão integrada e participativa. No âmbito da REMAP, os mosaicos de áreas protegidas são definidos como uma oportunidade para a articulação interinstitucional, com o intuito de promover a conservação e o desenvolvimento sustentável a nível regional. A ampla participação proporcionada pelo modelo de mosaico possibilita o diálogo e a solução de conflitos, aprimorando a gestão de áreas protegidas. Ainda conforme a REMAP, a gestão compartilhada possibilita a prática de ações conjuntas que sejam voltadas para o desenvolvimento territorial com base conservacionista, como por exemplo, esforços conjuntos visando a fiscalização da área, a educação ambiental, a pesquisa, o monitoramento, a implementação de projetos que visam a valorização da sociodiversidade e a regularização fundiária das áreas protegidas que fazem parte do bloco.

Ainda conforme entendimento da Rede de Mosaicos, o modelo de gestão proposto pelos mosaicos de áreas protegidas converge com o modelo pautado na governança territorial. O objetivo da governança territorial é garantir que as negociações sejam contínuas e que se assegure o planejamento territorial baseado na conservação da biodiversidade, na valorização sociocultural e no desenvolvimento sustentável. A governança territorial diz respeito à capacidade de determinada sociedade para se organizar, considerando o território, com o objetivo de gerir os assuntos públicos a partir da cooperação entre os diversos atores. As práticas de governança territorial foram 
recomendadas para a gestão de áreas protegidas durante o Congresso Mundial de Parques de Durban, em 2003 (CARDOSO et al., 2010).

Em 2002, a Lei do SNUC foi regulamentada pelo Decreto no 4 .340. Este Decreto, em seu Capítulo III, trata exclusivamente dos mosaicos, estabelecendo as diretrizes de gestão. Conforme as orientações contidas no Decreto no 4.340/2002, os mosaicos de áreas protegidas, para serem criados, devem primeiramente ser reconhecidos pelo MMA, a pedido do órgão gestor de uma das UCs proponentes. Ainda de acordo com o Decreto, os mosaicos deverão dispor de um Conselho Consultivo, o qual atuará como instância de gestão integrada das diversas UCs que fazem parte do Mosaico. A adesão ao mosaico, pelas UCs, não é obrigatória. Cada UC poderá optar pela sua inclusão ou não no mosaico de áreas protegidas a ser constituído.

O Decreto 4.340/2002 estabelece como função do Conselho Consultivo propor diretrizes e ações para compatibilizar, otimizar e integrar as atividades desenvolvidas em cada uma das UCs que fazem parte do mosaico, tendo em vista especialmente os usos nas fronteiras entre as diferentes UCs, o acesso às unidades, a fiscalização, o monitoramento, a avaliação dos Planos de Manejo, a pesquisa científica e a alocação dos recursos advindos da compensação referente ao licenciamento ambiental de empreendimentos com significativo impacto ambiental. Além disso, o Decreto em questão estabelece como função do Conselho Consultivo propor diretrizes e ações que visem compatibilizar os objetivos do mosaico com os interesses das populações residentes em seu interior, traduzindo um esforço de conciliação entre conservação e desenvolvimento das populações locais (CARDOSO et al., 2010).

O Decreto 4.340/2002 recomenda que os Conselhos Consultivos dos mosaicos tenham caráter multisetorial, ou seja, que sejam compostos por membros que representem diversos setores da sociedade. Deste modo, os conselheiros serão representantes: das diferentes UCs que compõem o mosaico, abarcando todas as esferas governamentais, das comunidades locais, de órgãos públicos com atuação em áreas afins, da comunidade científica, da população residente no entorno das UCs, dos proprietários de imóveis localizados no interior e entorno das UCs, do setor privado e de representantes dos Comitês de Bacias Hidrográficas da região. O caráter multisetorial do Conselho Consultivo dos mosaicos visa garantir a ampla participação social na gestão dos blocos de áreas protegidas. No entanto, a competência dos Conselhos dos mosaicos é consultiva, não sendo permitida a esta instância deliberar. 


\section{2- $\quad$ A PARTICIPAÇÃO SOCIAL NA GESTÃO DE UCs}

Desde meados da década de 1980, o Brasil passa por um processo de aperfeiçoamento da democracia e, com isto, a participação social nas tomadas de decisão públicas vem avançando de forma concomitante. Na Constituição Federal de 1988, a participação social recomendada para as tomadas de decisão representa o fortalecimento da democracia e da cidadania. Assim, o Estado brasileiro busca consolidar sua interação com a sociedade, visando colocar em prática a democracia participativa (MACEDO et al., 2014). A Constituição de 1988 recomenda que haja a participação da coletividade na proteção do meio ambiente, ao afirmar no Artigo 225 que:

Todos têm direito ao meio ambiente ecologicamente equilibrado, bem de uso comum do povo e essencial à sadia qualidade de vida, impondo-se ao poder público e à coletividade o dever de defendê-lo e preservá-lo para as presentes e futuras gerações (BRASIL, 1988).

Deste modo, o artigo constitucional abriu o caminho para a democracia participativa na gestão ambiental pública no Brasil, na medida em que estabeleceu a participação da coletividade na defesa do meio ambiente (MACEDO et al., 2014).

A Lei do SNUC recomenda que sejam formados conselhos nas UCs, para atuarem como instâncias de gestão participativa. Os conselhos das UCs são frutos das diretrizes traçadas na Constituição Federal de 1988 e representam espaços legítimos de diálogo entre sociedade e poder público em busca da gestão participativa. De acordo com o SNUC, a ampla participação deverá ocorrer em todas as etapas de gestão da UC, ou seja, não deve ser confinada apenas a determinados momentos e fases da gestão (MACEDO et al., 2014).

A gestão participativa vem sendo amplamente aceita como uma estratégia efetiva para garantir a proteção da natureza. Este modo de gerir as áreas protegidas encontra-se amparado em um conjunto de normativos que o legitima, como por exemplo o SNUC, a Constituição Federal de 1988 e o PNAP. Este último recomenda que a gestão seja participativa para todas as categorias de áreas protegidas, para que seja construído o diálogo entre os diversos setores da sociedade, visando aprimorar a efetividade na proteção à natureza. De acordo com o PNAP, os atores sociais devem manifestar-se e negociar entre si, participando ativamente no processo de decisão (MACEDO et al., 2014). 
A gestão de uma UC corresponde a um processo de mediação de interesses e conflitos diversos e, por isso, nem sempre é fácil atingir a negociação que conduzirá à tomada de decisão coletiva. O espaço de gestão de uma UC é complexo e, normalmente, é permeado por conflitos socioambientais. Este tipo de conflito é assim denominado quando for do tipo social e apresentar a dimensão ambiental de forma preponderante, de modo que esta influencie decisivamente no comportamento dos atores (MACEDO et al., 2014).

Para os autores, o conceito de participação é controvertido nas bases teóricas e ideológicas, pois há uma disputa semântica em torno do significado do vocábulo "participação". As várias concepções acerca da palavra participação podem ser agrupadas em três grupos conceituais distintos, sendo estes o liberal, o revolucionário e o democrático radical. Conforme a concepção liberal, a participação é concebida como um movimento espontâneo de indivíduos, inerente ao espírito humano e, desta forma, não determinado por interesses derivados das posições sociais dos atores. Já de acordo com a concepção revolucionária, a participação é entendida como um processo de organização popular na luta contra as relações de dominação e, para a democrática radical, ela é compreendida como um processo de fortalecimento da sociedade civil, em busca de uma nova ordem social.

Na presente pesquisa, os significados de participação que permeiam as análises são referentes às concepções revolucionárias e democrática radical. Isto porque na gestão de UCs, a participação é caracterizada pelo processo de negociação entre os diversos atores envolvidos, que normalmente possuem interesses conflitantes, o que demanda aprimoramento da organização popular para substituir relações de dominação por outras mais democráticas e igualitárias, visando a construção de uma nova ordem social. Para Macedo et al (2014), a avaliação da gestão participativa nas UCs depende, em primeiro plano, da definição do conceito e de sua abrangência. Isto porque a gestão participativa pode ser entendida como um processo que abrange apenas o nível da consulta ou ser concebido como a operacionalização de uma efetiva distribuição de poderes, que resulta na tomada de decisão com base nas determinações coletivas.

Atualmente, os esforços dos órgãos gestores, como o ICMbio, seguem rumo à construção de mecanismos de diálogo com a sociedade, de forma a abranger todas as instâncias e etapas da gestão, abrindo o leque da participação. A intenção é não restringir a gestão participativa ao espaço do conselho, ampliando-a de forma que abarque os processos de criação, implementação e consolidação da UC. Além disso, 
busca-se qualificar a gestão ambiental participativa, de modo que esta supere os limites da atuação consultiva e passe a influenciar cada vez mais as tomadas de decisão de forma deliberativa (MACEDO et al., 2014).

Outro aspecto bastante debatido é que para o alcance da efetividade de gestão em UCs, a gestão participativa deve ser qualificada. Neste sentido, destaca-se o papel da educação ambiental crítica que, segundo os autores, visa emancipar sujeitos postos à margem dos processos decisórios relativos à destinação de bens ambientais para uma participação qualificada nas tomadas de decisão. Ainda conforme o autor, a educação ambiental crítica tem por objetivo promover o exercício da cidadania ao democratizar o acesso aos bens e à gestão ambientais.

Em outras palavras, a gestão participativa em UCs corresponde a um processo de diálogo que requer um aprendizado constante, principalmente, no que se refere ao diálogo de saberes. Na gestão participativa, são considerados e combinados os diferentes tipos de conhecimento, visando aprimorar a proteção à natureza. Assim, a gestão participativa requer o diálogo entre o conhecimento técnico- científico e os conhecimentos tradicionais desenvolvidos pelas populações locais, de forma a assegurar a conservação da biodiversidade e os modos de vida dessas populações. Este intercâmbio de conhecimentos também é objetivo da Lei do SNUC, constando em seu Artigo 4ํㅡ, inciso XIII, da seguinte forma:

É objetivo da Lei do Sistema Nacional de Unidades de Conservação- SNUC proteger os recursos naturais necessários à subsistência de populações tradicionais, respeitando e valorizando seu conhecimento e sua cultura e promovendo-as social e economicamente (BRASIL, 2000).

\section{3- O SURGIMENTO DOS MOSAICOS DE ÁREAS PROTEGIDAS NO BRASIL}

Os mosaicos de áreas protegidas são instrumentos de gestão ambiental recomendados pela legislação brasileira, em específico pela Lei do SNUC. Os mosaicos são semelhantes ao modelo de gestão de áreas protegidas denominada de biorregional, desenvolvido por Kenton Miller na década de 1970. A Gestão Biorregional foi pioneira em propor a prática da conservação considerando uma escala maior. Em outras palavras, a Gestão Biorregional propôs trabalhar a conservação na escala do ecossistema, para evitar que as áreas protegidas se tornassem isoladas e dissociadas do restante da paisagem (ARRUDA, 2006).

Segundo Kenton Miller (1997), os aspectos considerados na Gestão Biorregional são: a prática da conservação em espaços amplos, suficientemente grandes para 
garantir a manutenção dos habitats e processos ecológicos necessários à preservação das espécies a longo prazo; a gestão integrada, que significa o compartilhamento do planejamento e das atividades de conservação entres os diversos atores; o estímulo à sustentabilidade econômica das populações que vivem dentro e no entorno da área a ser conservada, por meio de incentivos à exploração sustentável dos recursos naturais locais; a divisão justa dos custos e benefícios da conservação; a construção da capacidade local para a participação e negociação nos assuntos referentes à conservação; a garantia de participação na gestão da área a ser conservada para todas as partes que impactam seus recursos naturais ou deles se beneficiam; a aceitação social por parte das populações locais para as propostas de mudanças em seus modos de vida que sejam decorrentes das atividades de conservação; o uso da Tecnologia de Informações Geográficas, visando ampliar o conhecimento sobre a área a ser conservada; a realização de pesquisas para o aprimoramento dos métodos de gestão dos recursos naturais; o monitoramento voltado para a avaliação dos impactos decorrentes das atividades de conservação; a aplicação do conhecimento científico, local e tradicional no planejamento e na gestão da área a ser conservada; a aplicação do conhecimento oriundo dos diversos campos do saber, como a Antropologia, a Biologia, a Economia, a Engenharia, dentre outros; o desenvolvimento de projetos de forma experimental; a recuperação de áreas degradadas; o incentivo à gestão cooperativa; a integração institucional, visando otimizar o gerenciamento da área a ser conservada e minimizar os passivos administrativos; e o estímulo à cooperação internacional, visando o desenvolvimento de pesquisas conjuntas e o incremento nos investimentos.

O conceito de mosaico de áreas protegidas que consta no Artigo ํㅜ 26 da Lei do SNUC apresenta convergências com o modelo de gestão de áreas protegidas proposto por Miller, tais como: destinação de espaços amplos para os projetos de conservação, considerando a escala regional; recomendação para a prática da gestão integrada e participativa; conciliação entre conservação da biodiversidade e desenvolvimento das populações que residem na área a ser conservada e em seu entorno, por meio da valorização da sociodiversidade e de incentivos ao uso sustentável dos recursos naturais.

Apesar do conceito de mosaico de áreas protegidas ter surgido no Brasil com a criação da Lei do SNUC, em 2000, experiências que se aproximam do modelo já eram praticadas na década de 1990. Tais experiências referem-se a iniciativas de gestão integrada de UCs, destacando-se dentre elas a experiência do Núcleo Regional de 
Unidades de Conservação - NURUC, constituído em 1997 e incorporado posteriormente na estrutura do IBAMA. Dez UCs do Estado do Rio de Janeiro compuseram o NURUC.

A promoção da gestão integrada entre as UCs participantes era o objetivo principal do NURUC. Esta gestão visava minimizar os passivos administrativos. A motivação para a criação do NURUC esteve relacionada à necessidade de reverter o quadro de centralização burocrática excessiva atribuído à Superintendência do IBAMA do Estado do Rio de Janeiro. Na primeira fase de operacionalização do NURUC, a gestão integrada se deu em torno da gestão orçamentária das UCs, tendo sido ampliada para as demais atividades de gestão apenas a partir das fases operacionais posteriores. A Unidade Gestora do Parque Nacional da Serra dos Órgãos foi o polo catalizador do processo de integração das UCs do NURUC. Após conhecer os resultados provenientes da iniciativa inovadora, os gestores que formaram o NURUC passaram a divulgar em eventos institucionais os aspectos positivos oriundos de suas experiências, estimulando as práticas de gestão integrada nas UCs no Brasil (Boletim da Cooperação BrasilFrança sobre Áreas Protegidas, 2010).

A concepção do modelo referente aos Corredores Biorregionais também pode ser considerada uma experiência próxima ao modelo de mosaico que antecede a conceituação do mesmo na Lei do SNUC, ocorrida em 2000. O modelo referente aos Corredores Biorregionais foi institucionalizado no âmbito do Projeto Corredores Ecológicos- PCE, do Programa Piloto para a Proteção das Florestas Tropicais do BrasilPPG-7. A proposta para a criação dos Corredores Biorregionais foi formulada pelo biólogo José Márcio Ayres, em 1992, a princípio para os biomas Mata Atlântica e Amazônia (GANEM, 2011).

A construção do PCE no MMA remonta a 1997. Houve um longo trâmite e muita discussão até que o Projeto fosse formalizado. Em 1993, anteriormente ao início de sua construção dentro do MMA, o Projeto esteve sob a responsabilidade do IBAMA, tendo recebido o nome Projeto de Parques e Reservas. Dentre as discussões para a elaboração do Projeto, destaca-se o debate acerca da efetividade da criação de UCs de forma isolada e dissociada do restante da paisagem. O Projeto propunha uma reflexão mais abrangente, sugerindo um novo modelo que permitisse inserir as UCs num contexto ecossistêmico mais amplo para viabilizar a conservação ambiental a longo prazo, bem como situá-las em seus contextos econômico, social e político, de modo a se pensar a conservação de forma holística (MMA, 2014). 
Durante a elaboração do PCE, foram planejados sete Corredores Biorregionais, sendo que cinco deles localizavam-se nos biomas Amazônia e Mata Atlântica (três na Amazônia e dois na Mata Atlântica). A proposta inicial, elaborada pelos consultores do Banco Mundial, Márcio Ayres e Gustavo Fonseca, foi objeto de ampla discussão e de diversos ajustes, resultando em muitas diferentes versões elaboradas para do PCE. Na construção deste Projeto, participaram entidades de natureza diversa, como o Banco Mundial, IBAMA, FUNAI, CE (Comunidade Europeia), KFW (Banco de Desenvolvimento da Alemanha), GTZ (Agência de Cooperação Alemã) e organizações da sociedade civil atuantes nos biomas Amazônia e Mata Atlântica. A criação do PCE ocorreu apenas em 2002, depois de firmado o acordo de doação com o Banco Mundial, em 2001. Atualmente, o PCE está vinculado à Secretaria de Biodiversidade e Florestas do MMA (MMA, 2014).

Os Corredores Biorregionais se aproximam dos mosaicos por referirem-se também a grandes áreas destinadas para a conservação, constituídas de ecossistemas florestais biologicamente prioritários para a proteção, e por serem constituídos por um conjunto de UCs e demais áreas protegidas, como Terras Indígenas, APPs e RLs. De acordo com o MMA, a principal função dos Corredores Biorregionais é conservar os ecossistemas por meio de uma estratégia que visa reverter ou impedir o processo de fragmentação florestal. Assim como nos mosaicos, nos Corredores Biorregionais diferentes categorias de UCs e demais áreas protegidas estão conectadas entre si na paisagem, visando um fim comum: a conservação da natureza. A prática da conservação em um contexto regional mais amplo e a importância dada para a participação das comunidades locais na gestão da área destinada para a conservação são outras características dos Corredores Biorregionais que os aproximam dos mosaicos.

Desde sua criação em 2002, o PCE vem atuando nos Corredores Biorregionais. Os Corredores Central da Mata Atlântica (CCMA) e Central da Amazônia (CCA) foram os primeiros a serem criados, tendo por característica o caráter experimental. Para a implementação desses Corredores, foram selecionados dois biomas distintos, visando garantir a possibilidade de verificar a efetividade do modelo em condições distintas. $O$ PCE mapeou os biomas Amazônia e Mata Atlântica, definindo sete corredores prioritários, sendo dois na Mata Atlântica e cinco na Amazônia (ARRUDA et al., 2004). Os projetos de corredores biorregionais selecionados pelo MMA/PP-G7 em 2005 são apresentados no quadro abaixo: 


\begin{tabular}{|l|r|r|}
\hline \multicolumn{1}{|c|}{ Denominação } & UFs & Área (ha) \\
\hline $\begin{array}{l}\text { Corredor Ecológico Norte da } \\
\text { Amazônia }\end{array}$ & AM/RR & 21.000 .000 \\
\hline $\begin{array}{l}\text { Corredor Ecológico Central da } \\
\text { Amazônia }\end{array}$ & AM/RR/PA & 49.148 .900 \\
\hline $\begin{array}{l}\text { Corredor Ecológico Sul da } \\
\text { Amazônia }\end{array}$ & AM/PA/TO/MA & 31.646 .600 \\
\hline $\begin{array}{l}\text { Corredor Ecológico Ecótonos } \\
\text { Sul-Amazônicos }\end{array}$ & RO/MT/PA/TO & 46.258 .700 \\
\hline $\begin{array}{l}\text { Corredor Ecológico Oeste da } \\
\text { Amazônia }\end{array}$ & AC/AM/RO & 27.242 .700 \\
\hline $\begin{array}{l}\text { Corredor Ecológico Central da } \\
\text { Mata Atlântica }\end{array}$ & MG/SP/RJ & 9.409 .000 \\
\hline $\begin{array}{l}\text { Corredor Ecológico da Serra do } \\
\text { Mar }\end{array}$ & & 6.924 .100 \\
\hline \multicolumn{1}{|c|}{ Total } & & 191.630 .000 \\
\hline
\end{tabular}

Quadro 1- Projetos de Corredores Biorregionais Selecionados pelo PCE em 2005.

Fonte: ARRUDA, Moacir Bueno e SÁ, Luís Fernando S. (orgs.) Corredores Ecológicos: Uma abordagem integradora de ecossistemas no Brasil. Brasília: IBAMA/MMA, 2004.

Assim como nos mosaicos, nos Corredores Biorregionais visa-se promover mudanças de comportamento nos atores envolvidos com o uso da área destinada à conservação. Para isto, são incentivados o uso sustentável dos recursos naturais e inserido o viés ambiental nos projetos de desenvolvimento elaborados para a área do Corredor (MMA, 2014). Além disso, tanto na gestão de Corredores Biorregionais, como na de mosaicos, ocorrem esforços voltados para incentivos à gestão interinstitucional, que significa a promoção de parcerias entre as diversas instituições que atuam na área do Corredor Biorregional ou do mosaico.

A gestão integrada no nível institucional visa otimizar a gestão por meio do compartilhamento das responsabilidades decorrentes do objetivo principal de conservação ambiental. As instituições envolvidas na gestão dos corredores e dos mosaicos poderão ser de natureza governamental, envolvendo os três diferentes níveis de governo (federal, estadual e municipal), bem como de natureza não governamental ou privada, envolvendo a participação de ONGs e de organizações da sociedade civil, como por exemplo, os sindicatos, as associações e os movimentos sociais organizados, além de entidades pertencentes ao setor privado.

O primeiro mosaico de áreas protegidas que surgiu no Brasil remonta ao ano de 2002, sendo este o Mosaico do Tucuruí, localizado no Estado do Pará. Porém, a maior parte dos mosaicos surgiram entre os anos de 2005 e 2006, e em 2010, em razão do Edital no 01/2005 lançado pelo Fundo Nacional de Meio Ambiente- FNMA (REMAP, 
2014). O lançamento deste Edital destaca-se como a principal iniciativa propulsora da criação de mosaicos no Brasil. O objetivo do Edital foi selecionar projetos para a criação de mosaicos nos diversos biomas brasileiros, tendo por base a estratégia de Desenvolvimento Territorial de Base Conservacionista- DTBC. O Edital disponibilizou um total de quatro milhões de reais para apoiar os projetos, prevendo duas Chamadas distintas: a Chamada I, específica para o bioma Amazônia, e a Chamada II, abrangendo os demais biomas brasileiros, como a Mata Atlântica, a Caatinga, o Cerrado, os Campos Sulinos e o Pantanal, bem como a Zona Costeira e Marinha (MACIEL, 2007).

Para a Chamada I, foi exigida a incorporação na composição do mosaico de, no mínimo, uma UC de proteção integral vinculada ao Programa Áreas Protegidas da Amazônia - ARPA. O ARPA é um programa do Governo Federal que visa o desenvolvimento sustentável da região amazônica e o fortalecimento do SNUC por meio de ações conservacionistas no bioma Amazônia. Coordenado na atualidade pelo MMA e pelo ICMBio, o ARPA conta com parcerias dos governos estaduais e municipais da Amazônia, do Fundo Global para o Meio Ambiente - GEF, do Banco Interamericano de Desenvolvimento- BID, do Banco de Cooperação Alemã - KFW, da Cooperação Técnica Alemã - GTZ, do Fundo Mundial para Vida Silvestre/Brasil - WWF/Brasil e do Fundo Brasileiro para a Biodiversidade - FUNBIO (ARPA, 2014).

Conforme o ARPA, é função do Programa desenvolver atividades de proteção ambiental e desenvolvimento sustentável na Amazônia, por meio da criação e consolidação de UCs de proteção integral e de uso sustentável. Dentre as ações do Programa destacam-se o financiamento e a sustentabilidade das áreas protegidas, 0 monitoramento e o desenvolvimento de estratégias para a conservação da diversidade biológica e o apoio ao desenvolvimento das comunidades locais. É meta do ARPA colocar sob regime de proteção aproximadamente 60 milhões de hectares de florestas localizadas no bioma Amazônia.

De acordo com o Edital FNMA no 01/2005, a estratégia de DTBC consiste em estabelecer formas de associação entre desenvolvimento e conservação da natureza em um determinado território, composto por UCs, outras áreas legalmente protegidas, e de suas respectivas zonas de interstícios. O objetivo principal do DTBC consiste no estabelecimento e fortalecimento de cadeias produtivas baseadas no manejo sustentável dos recursos naturais e na gestão ecossistêmica do território. As estratégias de DTBC visam a melhoria da qualidade de vida das populações locais de forma associada à conservação dos recursos naturais. O desafio do DTBC consiste em gerar 
renda através de atividades produtivas que também possam apresentar resultados favoráveis à conservação ambiental.

O Edital FNMA nº 01/2005 permitiu a participação de instituições públicas pertencentes à administração direta e indireta e de instituições privadas sem fins lucrativos na categoria de instituição proponente dos projetos. As últimas, para obterem apoio do FNMA por meio do Edital, deveriam comprovar atuação na área ambiental e serem identificadas como: organização ambientalista, fundação de apoio à universidade, organização de base ou organização de apoio.

O Edital do FNMA nº 01/2005 obteve o título de "Mosaicos de Áreas Protegidas: Uma estratégia de desenvolvimento territorial de base conservacionista". O documento apresentou como orientação para a elaboração dos projetos: a consideração das políticas, planos, programas, projetos e demais instrumentos de gestão porventura existentes na área a ser criado o mosaico e que possam influenciar no desenvolvimento do projeto; o planejamento participativo que garanta a gestão integrada no mosaico; o encaminhamento ao MMA da proposta de criação do mosaico e de seu respectivo Conselho Consultivo; a apresentação de um Plano de DTBC; o planejamento para a elaboração do regimento interno do mosaico, bem como a observância da legislação ambiental no âmbito federal, estadual e municipal.

Ainda, o referido Edital do FNMA recomendou que os projetos se guiassem por uma abordagem orientada para: a valorização dos aspectos culturais das comunidades locais, dando oportunidade para a prática do saber local no processo de gestão do mosaico; o equilíbrio das relações de gênero em todas as suas fases; a garantia de continuidade das ações; a implementação eficaz do plano de DTBC; a promoção da gestão integrada e participativa; a divulgação das atividades desenvolvidas e dos resultados alcançados no âmbito do mosaico; a construção de estratégias para facilitar o acesso à informação útil à gestão do mosaico e ao funcionamento de seu Conselho Gestor; o incentivo à criação de parcerias com as comunidades locais e envolvimento dos técnicos das áreas protegidas que irão compor o mosaico em sua proposta de criação e gestão.

Consta no Edital FNMA no 01/2005 como resultados esperados: a gestão integrada de territórios por meio do estabelecimento de, no mínimo, quatro mosaicos no bioma Amazônia e, no mínimo, seis mosaicos nos demais biomas e na Zona Costeira e Marinha; a construção de uma identidade territorial a partir das UCs e demais áreas 
protegidas; o estabelecimento e a consolidação de parcerias institucionais, visando a implementação do DTBC; o fortalecimento do SNUC; o estabelecimento de procedimentos para a gestão integrada e participativa de mosaicos por meio da estratégia de DTBC; a mobilização e organização comunitária favorável ao DTBC e a identificação e desenvolvimento de territórios.

O Edital exigiu como produto esperado por projeto: o ato de reconhecimento do mosaico e a formação de seu Conselho Consultivo; a elaboração do regimento interno do Conselho, com a respectiva aprovação; um Plano de DTBC; e a produção de cartilha voltada para a divulgação da experiência de formação e implementação do mosaico. 0 Edital do FNMA no 01/2005 selecionou projetos que deram origem a mosaicos no Brasil, dentre eles o projeto referente ao MBRN, objeto do estudo de caso da presente pesquisa.

Atualmente existem no Brasil quatorze mosaicos reconhecidos oficialmente pelo MMA, conforme demonstrado no quadro abaixo:

\begin{tabular}{|c|c|c|c|c|}
\hline Mosaico & Estados & Biomas & UCs & Portaria \\
\hline $\begin{array}{l}\text { Do Oeste do } \\
\text { Amapá e } \\
\text { Norte do Pará }\end{array}$ & Amapá e Pará & $\begin{array}{c}\text { Floresta } \\
\text { Amazônica }\end{array}$ & $\begin{array}{l}\text { Federais, } \\
\text { estaduais, } \\
\text { municipais e } \\
\text { Terras } \\
\text { Indígenas }\end{array}$ & $\begin{array}{l}\text { MMA no } 04, \\
\text { de } 03 \text { de } \\
\text { janeiro de } \\
2013 .\end{array}$ \\
\hline Do Lagamar & $\begin{array}{l}\text { São Paulo e } \\
\text { Paraná }\end{array}$ & $\begin{array}{c}\text { Mata } \\
\text { Atlântica }\end{array}$ & $\begin{array}{l}\text { Federais, } \\
\text { estaduais e } \\
\text { municipais }\end{array}$ & $\begin{array}{l}\text { MMA no } 150, \\
\text { de } 08 \text { de maio } \\
\text { de } 2006 .\end{array}$ \\
\hline Bocaina & $\begin{array}{l}\text { Rio de Janeiro } \\
\text { e São Paulo }\end{array}$ & $\begin{array}{c}\text { Mata } \\
\text { Atlântica }\end{array}$ & $\begin{array}{l}\text { Federais, } \\
\text { estaduais e } \\
\text { municipais }\end{array}$ & $\begin{array}{c}\text { MMA no } 349, \\
\text { de } 11 \text { de } \\
\text { dezembro de } \\
2006 .\end{array}$ \\
\hline $\begin{array}{c}\text { Da Amazônia } \\
\text { Meridional }\end{array}$ & $\begin{array}{l}\text { Amazonas, } \\
\text { Mato Grosso e } \\
\text { Rondônia }\end{array}$ & $\begin{array}{l}\text { Floresta } \\
\text { Amazônica }\end{array}$ & $\begin{array}{l}\text { Federais, } \\
\text { estaduais e } \\
\text { municipais }\end{array}$ & $\begin{array}{l}\text { MMA no } 332, \\
\text { de } 25 \text { de } \\
\text { agosto de } \\
2011 .\end{array}$ \\
\hline $\begin{array}{c}\text { Da Foz do Rio } \\
\text { Doce }\end{array}$ & Espírito Santo & Cerrado & $\begin{array}{l}\text { Federais, } \\
\text { estaduais e } \\
\text { municipais }\end{array}$ & $\begin{array}{c}\text { MMA no } 489, \\
\text { de } 17 \text { de } \\
\text { dezembro de } \\
2010 .\end{array}$ \\
\hline $\begin{array}{l}\text { Do Extremo } \\
\text { Sul da Bahia }\end{array}$ & Bahia & Mata Atlântica & $\begin{array}{l}\text { Federais, } \\
\text { estaduais e } \\
\text { municipais }\end{array}$ & $\begin{array}{l}\text { MMA no 492, } \\
\text { de } 17 \text { de } \\
\text { dezembro de } \\
2010\end{array}$ \\
\hline $\begin{array}{l}\text { Do Espinhaço: } \\
\text { Alto } \\
\text { Jequitinhonha- }\end{array}$ & Minas Gerais & Cerrado & $\begin{array}{l}\text { Federais, } \\
\text { estaduais e } \\
\text { municipais }\end{array}$ & $\begin{array}{c}\text { MMA no } 444, \\
\text { de } 26 \text { de }\end{array}$ \\
\hline
\end{tabular}




\begin{tabular}{|c|c|c|c|c|}
\hline $\begin{array}{l}\text { Serra do } \\
\text { Cabral }\end{array}$ & & & & $\begin{array}{c}\text { novembro de } \\
2010\end{array}$ \\
\hline $\begin{array}{c}\text { Do Baixo Rio } \\
\text { Negro }\end{array}$ & Amazonas & $\begin{array}{c}\text { Floresta } \\
\text { Amazônica }\end{array}$ & $\begin{array}{l}\text { Federais, } \\
\text { estaduais e } \\
\text { municipais }\end{array}$ & $\begin{array}{c}\text { MMA no } 483 \text {, } \\
\text { de } 14 \text { de } \\
\text { dezembro de } \\
2010 .\end{array}$ \\
\hline $\begin{array}{l}\text { Mico-Leão- } \\
\text { Dourado }\end{array}$ & Rio de Janeiro & Mata Atlântica & $\begin{array}{l}\text { Federais, } \\
\text { estaduais e } \\
\text { municipais }\end{array}$ & $\begin{array}{c}\text { MMA no } 481 \text {, } \\
\text { de } 14 \text { de } \\
\text { dezembro de } \\
2010 .\end{array}$ \\
\hline $\begin{array}{l}\text { Capivara- } \\
\text { Confunsões }\end{array}$ & Piauí & Caatinga & $\begin{array}{l}\text { Federais, } \\
\text { estaduais e } \\
\text { municipais }\end{array}$ & $\begin{array}{l}\text { MMA no } 76, \\
\text { de } 11 \text { de } \\
\text { março de } \\
2005 .\end{array}$ \\
\hline $\begin{array}{c}\mathrm{Da} \\
\text { Mantiqueira }\end{array}$ & $\begin{array}{l}\text { Rio de Janeiro, } \\
\text { São Paulo e } \\
\text { Minas Gerais }\end{array}$ & Mata Atlântica & $\begin{array}{l}\text { Federais, } \\
\text { estaduais e } \\
\text { municipais }\end{array}$ & $\begin{array}{l}\text { MMA no } 351, \\
\text { de } 11 \text { de } \\
\text { dezembro de } \\
2006 \text {. }\end{array}$ \\
\hline Carioca & Rio de Janeiro & Mata Atlântica & $\begin{array}{l}\text { Federais, } \\
\text { estaduais e } \\
\text { municipais }\end{array}$ & $\begin{array}{l}\text { MMA no } 245, \\
\text { de } 11 \text { de julho } \\
\text { de } 2005 .\end{array}$ \\
\hline $\begin{array}{c}\text { Grande Sertão } \\
\text { Veredas- } \\
\text { Peruaçu }\end{array}$ & Minas Gerais & Cerrado & $\begin{array}{l}\text { Federais, } \\
\text { estaduais e } \\
\text { municipais }\end{array}$ & $\begin{array}{l}\text { MMA no } 128, \\
\text { de } 24 \text { de abril } \\
\text { de } 2009 .\end{array}$ \\
\hline $\begin{array}{c}\text { Mata } \\
\text { Atlântica- } \\
\text { Central } \\
\text { Fluminense }\end{array}$ & Rio de Janeiro & Mata Atlântica & $\begin{array}{l}\text { Federais, } \\
\text { estaduais e } \\
\text { municipais }\end{array}$ & $\begin{array}{l}\text { MMA no } 350, \\
\text { de } 11 \text { de } \\
\text { dezembro de } \\
2006 \text {. }\end{array}$ \\
\hline
\end{tabular}

Quadro 2- Mosaicos Oficialmente Reconhecidos no Brasil. Fonte: ICMbio, 2014.

Além dos quatorze mosaicos federais reconhecidos pelo MMA, foram também criados mosaicos estaduais, como por exemplo, o Mosaico de Unidades de Conservação do Lago de Tucuruí, no Pará. Disciplinar e regularizar a ocupação do solo e o uso dos recursos naturais da região foram os principais objetivos que nortearam a criação do Mosaico do Tucuruí. A criação deste mosaico contou com recursos da compensação ambiental decorrentes da implantação da Usina Hidrelétrica de Tucuruí, no Estado do Pará (GHILARDI et al., 2007).

Reconhecido oficialmente em 08 de abril de 2002, por meio da Lei Estadual $\mathrm{n}^{0}$ 6.451, o Mosaico de Unidades de Conservação do Lago de Tucuruí é considerado o primeiro mosaico criado no Brasil. Constituído pela APA do Lago de Tucuruí e pelas RDS Alcobaça e pela RDS Pucuruí-Ararão, o mosaico conta também com duas Zonas de Preservação da Vida Silvestre - ZPVS, as quais foram criadas e incorporadas ao 
mosaico por terem sido áreas destinadas à soltura de animais silvestres durante a fase de enchimento do reservatório (GHILARDI et al., 2007).

A ideia de se criar um mosaico na região do Lago de Tucuruí remonta à década de 1990. As discussões para o alcance deste propósito se iniciaram em 1993. A primeira proposta foi a de criação de uma RESEX abrangendo as ilhas do reservatório. Visando a criação da RESEX, estudos biológicos, socioeconômicos e fundiários da região foram realizados com o objetivo de embasar a proposta. No entanto, o Centro Nacional de Desenvolvimento Sustentado das Populações Tradicionais - CNPT/IBAMA, atualmente denominado CNPT/ICMBio - Centro Nacional de Pesquisa e Conservação da Sociobiodiversidade Associada a Povos e Comunidades Tradicionais, com base nos estudos realizados, emitiu parecer favorável à sustação da criação da RESEX. Na ocasião, o CNPT entendeu que os estudos apontavam para o fato de que a população extrativista existente na região não era representativa o suficiente para a criação de uma RESEX na região.

Diante deste cenário, os moradores locais da região do Lago de Tucuruí encaminharam solicitação de revisão do parecer do CNPT ao MMA, alegando que os estudos nos quais o parecer se baseou foram insuficientes para sustentar uma conclusão consistente. Assim, os moradores locais de Tucuruí solicitaram ao MMA a realização de estudos complementares, para melhor embasar a decisão de criação da RESEX. Na ocasião, o MMA decidiu por atender à solicitação dos moradores de Tucuruí e realizar os estudos complementares. Para isto, foi firmado um convênio com o Conselho Nacional dos Seringueiros - CNS, que contou com a coordenação técnica do Instituto Sociedade, População e Natureza - ISPN. Por fim, os resultados obtidos pelos estudos complementares acabaram por corroborar para a decisão de criação da RESEX na região do Lago do Tucuruí (GHILARDI et al., 2007).

A proposta de criação da RESEX foi então submetida a debates no fórum das entidades locais. Na ocasião, esta instância decidiu por discutir a proposta de forma mais ampla, trazendo para o debate outros atores, como os representantes do setor privado, as associações de pescadores e das comunidades locais, os órgãos ambientais governamentais das esferas federal, estadual e municipal, os sindicatos de trabalhadores rurais, as ONGs, dentre outros atores. Foram realizadas reuniões e oficinas de trabalho, contando com a participação de diversas entidades. Nesses encontros, o fórum discutiu sobre o tipo de categoria de UCs que seria mais adequado 
para criação na área de influência da Usina Hidrelétrica de Tucuruí (GHILARDI et al., 2007).

Em 1999, o MMA reuniu-se com o Conselho Nacional dos Seringueiros - CNS para dar prosseguimento à proposta de criação de UCs na região do Lago do Tucuruí. $\mathrm{Na}$ ocasião da reunião, foi assinado um acordo entre as entidades participantes para a formação de uma comissão paritária. A função da comissão resumia-se em selecionar áreas originadas pelo enchimento do reservatório de Tucuruí, bem como propor um macrozoneamento que definisse os perímetros das UCs e suas respectivas categorias. Os estudos da comissão resultaram na proposta de criação do Mosaico de Unidades de Conservação do Lago de Tucuruí, oficialmente criado por lei estadual em 2002 (GHILARDI et al., 2007).

A criação do Mosaico do Tucuruí foi uma consequência da busca por soluções para os conflitos existentes na região, devido às ocupações irregulares e ao uso desordenado de seus recursos naturais. Os conflitos ocorridos na região levaram os movimentos sociais locais a se organizarem com o intuito de assegurar às populações locais o acesso e uso dos recursos naturais da região. Aos movimentos sociais, uniramse órgãos públicos federais, estaduais e municipais responsáveis pela gestão ambiental da região, visando assegurar o uso sustentável dos recursos naturais pelas populações locais, promovendo desta forma a conservação da natureza na região do Lago de Tucuruí (GHILARDI et al., 2007). A principal e primeira motivação para a criação do Mosaico foi, portanto, social e econômica. O objetivo de conservação da natureza foi agregado ao processo apenas posteriormente.

Visando conciliar os objetivos de desenvolvimento social e econômico das populações locais e os objetivos de conservação da natureza, optou-se pela criação de um mosaico composto por três UCs de uso sustentável, sendo elas: duas Reservas de Desenvolvimento Sustentável - RDS e uma Área de Proteção Ambiental - APA.

\section{4- MOSAICOS BRASILEIROS: UM CENÁRIO DE PARTICULARIDADES}

De acordo com as informações constantes nos bancos de dados do MMA, os quatorze mosaicos federais reconhecidos no Brasil apresentam a seguinte distribuição por bioma: sete estão localizados na Mata Atlântica, três no bioma Amazônia, três no bioma Cerrado e um no bioma Caatinga. A Mata Atlântica é o bioma que possui o maior 
número de mosaicos federais. Os mosaicos foram criados na Mata Atlântica com o propósito de minimizar os impactos da fragmentação florestal sobre a biodiversidade, visto que a Mata Atlântica é o bioma que apresenta o maior grau de fragmentação. No bioma Amazônia, ocorre o oposto, os mosaicos foram criados para auxiliar na prevenção do processo de fragmentação florestal, já que na Amazônia a fragmentação florestal não é tão intensa como na Mata Atlântica.

Conforme a REMAP, além dos mosaicos federais, existe também no Brasil os mosaicos estaduais, distribuídos pelos diversos biomas. Os mosaicos estaduais são criados por lei específica estadual, como por exemplo, o Mosaico de Unidades de Conservação de Jacupiranga, criado pela Lei Estadual no 12.810, de 21 de fevereiro de 2008. A criação, implementação e gestão dos mosaicos estaduais também seguem as orientações traçadas na Lei do SNUC e em seu Decreto Regulamentador n 4.340/2002, além de observar as determinações da lei estadual.

Os mosaicos criados no Brasil cobrem áreas extensas. A área do mosaico geralmente abarca um ou mais estados. Os mosaicos estão situados em áreas terrestres e na Zona Marinho Costeira. O Mosaico da Bocaina constitui um exemplo de mosaico situado em área litorânea. Este mosaico abrange parte do litoral sul do Estado do Rio de Janeiro e parte do litoral norte do Estado de São Paulo (ALBUQUERQUE \& LINO, 2007). A maioria dos mosaicos é constituída de UCs e demais áreas protegidas que encontram-se geograficamente próximas umas das outras, formando um bloco contínuo de espaços especialmente protegidos destinados à conservação.

No entanto, há mosaicos que não se enquadram nas definições descritas acima. O Mosaico Capivara-Confunsões constitui um bom exemplo, pois é formado por apenas duas UCs de proteção integral (PARNA Serra da Capivara e PARNA das Confunsões). Porém, comumente, os mosaicos apresentam em sua constituição uma combinação de UCs de proteção integral e de uso sustentável, cada uma com seus objetivos e metodologias de conservação. Esta realidade dos mosaicos torna o diálogo entre os gestores das UCs e o estabelecimento de objetivos comuns fundamentais à prática da boa gestão.

A criação dos mosaicos no Brasil se deu, na maioria dos casos, a partir da definição de um espaço geográfico constituído por UCs e demais áreas protegidas já criadas e categorizadas. Assim, os mosaicos criados no Brasil tiveram a função de 
unificar a gestão de UCs e demais áreas protegidas que já haviam sido criadas, e que a ele aderiram posteriormente, visando a prática da gestão integrada. O Mosaico da Bocaina, da Mantiqueira, Central Fluminense, da Amazônia Meridional, do Espinhaço, Sertão Veredas-Peruaçu, Mico-Leão-Dourado e da Foz do Rio Doce são exemplos de mosaicos que foram criados a partir da adesão de UCs e demais áreas protegidas préexistentes ao mosaico (ALBUQUERQUE \& LINO, 2007; AZEVEDO et al., 2009; ICMbio, 2014; Associação Mico Leão Dourado, 2014).

Há mosaicos que foram criados a partir de uma metodologia diversa, como é o caso do Mosaico do Jacupiranga, criado pela esfera de poder estadual. Segundo a lei de criação, o Mosaico do Jacupiranga está localizado no Estado de São Paulo, tendo sido criado a partir da alteração dos limites do Parque Estadual de Jacupiranga, atribuindo a esta UC novas denominações por subdivisões e reclassificações. Na criação deste mosaico, foram incluídas novas áreas, bem como excluídos espaços que previamente faziam parte do Parque Estadual (PAREST) de Jacupiranga.

Para criar o mosaico, o PAREST de Jacupiranga foi subdividido em três novos Parques Estaduais, sendo estes: o PAREST da Caverna do Diabo, o PAREST do Rio Turvo e o PAREST do Lagamar de Cananéia. Estas UCs representam a categoria de proteção integral que constitui o mosaico, formando seu núcleo. Além desta subdivisão, na criação do mosaico, foram instituídas novas UCs de uso sustentável abarcando novas áreas, bem como abrangendo áreas que pertenciam inicialmente ao PAREST de Jacupiranga, sendo elas: cinco Reservas de Desenvolvimento Sustentável, duas Reservas Extrativistas e quatro Áreas de Proteção Ambiental. A substituição de áreas do PAREST de Jacupiranga por UCs de uso sustentável e a criação destas em novas áreas abrangidas pelo mosaico foram motivadas em razão da existência de comunidades tradicionais residindo dentro da área do antigo PAREST de Jacupiranga (LINO, 2009).

Apesar da alteração dos limites do PAREST de Jacupiranga, por meio da recategorização e reclassificação de sua área de proteção integral, esta não apresentou redução devido à criação do mosaico, visto que paralelamente houve a incorporação de novas áreas. A partir da criação do mosaico, a área destinada à proteção integral passou a representar um total de aproximadamente 154.870,00 hectares. O antigo PAREST de Jacupiranga, criado pelo Decreto no 145, de 1969, abarcava uma área de 
cerca de 150.000,00 hectares. Assim, com a criação do mosaico a área destinada à proteção integral aumentou em termos de cobertura (LINO, 2009).

O atual Mosaico de Jacupiranga abrange uma área de 243.885,78 hectares. Fazem parte do mosaico quatorze unidades de conservação distribuídas nas categorias de UCs de proteção integral e de uso sustentável. O novo ordenamento territorial proporcionado por meio da criação do mosaico visa possibilitar a melhoria das condições de vida das comunidades tradicionais que residem na área do mosaico, aliando a este propósito objetivos de conservação da natureza (LINO, 2009). Diante deste cenário, conclui-se que os mosaicos são instrumentos de resolução de conflitos socioambientais, capazes de conciliar objetivos de desenvolvimento das populações locais e de conservação ambiental.

Os mosaicos foram estabelecidos em áreas prioritárias para a conservação, como é o caso dos mosaicos situados na Mata Atlântica, pois este bioma é considerado um hotspot (ALBUQUERQUE \& LINO, 2007; LINO, 2009). O conceito de "hotspot" foi criado pelo ecólogo inglês Norman Myers para solucionar o problema referente à seleção de áreas prioritárias para a conservação. Como a biodiversidade não se encontra distribuída de modo uniforme sobre o planeta, Myers propôs priorizar a conservação em áreas onde a biodiversidade é mais abundante e, no entanto, sofre maiores ameaças de destruição. Deste modo, um hotspot é uma área de alta biodiversidade, ameaçada no mais alto grau ( $\mathrm{Cl}$, 2014). Os biomas brasileiros Mata Atlântica e Cerrado são considerados hotspots mundiais. Consequentemente, os mosaicos neles inseridos situam-se em áreas prioritárias para a conservação.

Alguns mosaicos apresentam sobreposições com relação a outros instrumentos de gestão ambiental voltado para a conservação e para o desenvolvimento sustentável. Por exemplo, na Mata Atlântica ocorre significativa sobreposição dos mosaicos com a Reserva da Biosfera da Mata Atlântica - RBMA. Isto ocorre porque a RBMA cobre grande parte deste bioma. Também, alguns mosaicos situados na Mata Atlântica, como o Mosaico da Bocaina, Central Fluminense e da Mantiqueira se sobrepõem ao Corredor da Serra do Mar. Este Corredor é do tipo Biorregional, sendo seus objetivos bastante similares aos dos mosaicos nele inseridos. A criação de mosaicos no Corredor da Serra do Mar resultou das ações do Projeto de Apoio ao Reconhecimento dos Mosaicos no Corredor da Serra do Mar (ALBUQUERQUE \& LINO, 2007). 
O objetivo do Projeto era o fortalecimento dos Corredores Biorregionais e dos mosaicos, visando promover a gestão de UCs e demais áreas protegidas de forma integrada e articulada com a região do entorno. O Projeto foi coordenado pelo Conselho Nacional da Reserva da Biosfera da Mata Atlântica, tendo sido executado por meio de contrato firmado entre o Conselho da RBMA e o Fundo de Parceria para Ecossistemas Críticos - CEPF. O Fundo é uma iniciativa conjunta da Conservação Internacional - CI, do GEF, do Governo do Japão, da Fundação McArthur e do Banco Mundial para apoiar mundialmente as ações de conservação consideradas prioritárias (ALBUQUERQUE \& LINO, 2007). Neste contexto de criação de mosaicos no Corredor da Serra do Mar, a sobreposição de políticas de gestão ambiental foi promovida com o intuito de incrementar as ações de conservação na região por meio de uma gestão mais eficaz, visando o alcance de melhores resultados. A sobreposição de políticas ambientais, neste contexto específico, é resultado da soma de esforços em prol da conservação.

É objetivo dos mosaicos criados no Brasil a conservação dos recursos naturais. Porém, cada mosaico funciona tendo por base sua prioridade específica de conservação. Por exemplo, de acordo com o Instituto de Pesquisas da Amazônia- IPAM, no Mosaico da Amazônia Meridional prioriza-se a conservação dos estoques de carbono mantidos pelas espécies arbóreas da região, os quais são significativos e de grande importância para a regulação do clima. Localizado no Arco do Desmatamento, o Mosaico da Amazônia Meridional foi criado com o objetivo de conter o desmatamento que avança rapidamente na região. O Arco do Desmatamento é constituído por uma área de $500.000 \mathrm{Km}^{2}$, localizada nos estados do Pará, Mato Grosso, Rondônia e Acre. $\mathrm{Na}$ área do Arco do Desmatamento, ocorre significativo avanço da fronteira agrícola em direção à floresta. É nesta área que ocorrem os mais altos índices de desmatamento da Amazônia.

Assim, os mosaicos contribuem para a mitigação das mudanças climáticas, na medida em que contribuem para a contenção do desmatamento. Já existem casos de mosaicos que desenvolvem projetos de Redução de Emissões por Desmatamento e Degradação Florestal - REDD, como por exemplo, o Mosaico do Apuí, localizado no Estado do Amazonas. A área abrangida por este mosaico está inserida nos limites do Mosaico da Amazônia Meridional, ocorrendo portanto uma sobreposição de mosaicos na região. O Mosaico do Apuí possui uma área de aproximadamente 2,46 milhões de hectares, constituída por nove UCs de categorias diferentes, sendo estas: quatro 
Florestas Estaduais, dois Parques Estaduais, duas Reservas de Desenvolvimento Sustentável e uma Reserva Extrativista (FAS, 2014).

Os projetos de REDD são implementados com o objetivo de reduzir as emissões de Gases de Efeito Estufa - GEE - oriundas do desmatamento. Os países em desenvolvimento que implementarem projetos de REDD e comprovarem reduções das emissões de GEE em razão da contenção do desmatamento em seu território obterão incentivos e compensações financeiras. Os projetos de REDD visam estimular uma economia de baixa emissão, na qual as atividades são desenvolvidas considerando também a preservação das florestas (ALENCAR et al., 2012).

O Projeto de REDD do Mosaico do Apuí foi iniciado em maio de 2010. A construção do Projeto ocorreu de forma participativa, com o envolvimento das diversas instituições que atuam no mosaico, como a Fundação Amazonas Sustentável - FAS (ONG ambientalista), a Secretaria de Meio Ambiente e Desenvolvimento Sustentável do Amazonas - SDS, o Centro Estadual de Unidades de Conservação - CEUC, o Centro Estadual de Mudanças Climáticas - Ceclima, o Instituto de Conservação e Desenvolvimento Sustentável do Amazonas - IDESAM, dentre outras instituições. O Projeto de REDD implementado no Mosaico do Apuí visa, além da contenção do desmatamento para a redução das emissões de GEE, a captação de recursos para o desenvolvimento de atividades sustentáveis na área do mosaico (FAS, 2014).

Diferentemente, no Mosaico da Mantiqueira, localizado no bioma Mata Atlântica, os recursos hídricos representam a prioridade para a conservação. Isto ocorre porque este mosaico está localizado na região da Serra do Mar, considerada uma das regiões com maior provimento de água mineral do planeta. Os recursos hídricos oriundos da Serra do Mar abastecem diversas bacias hidrográficas de significativa importância para a economia do país, como por exemplo a Bacia do Paraná e a Bacia da Paraíba do Sul.

As bacias hidrográficas abastecidas pelos recursos hidrícos provenientes da Serra da Mantiqueira, área abrangida pelo mosaico, são fontes de geração de energia e de abastecimento dos principais centros industriais do país (ALBUQUERQUE \& LINO, 2007). Diante deste contexto, depreende-se que cada um dos mosaicos baseia-se numa determinada prioridade de conservação. Isto ocorre porque cada mosaico apresenta suas particularidades com relação aos aspectos biológicos, geográficos, sociais, econômicos, históricos e culturais. 
Há mosaicos no Brasil que abarcam espaços urbanos extensos. Por exemplo, a área do Mosaico da Mantiqueira abrange trinta e sete municípios dos estados de Minas Gerais, São Paulo e Rio de Janeiro. As cidades representam um significativo desafio para a gestão dos mosaicos voltada para a conservação ambiental, pois os centros urbanos concentram problemas ambientais de difícil solução, tais como: a ocupação acelerada e desordenada do solo, falta de saneamento básico para uma população numerosa, mal gerenciamento dos resíduos sólidos gerados, dentre outros. A sustentabilidade das cidades é tema que vem sendo debatido amplamente pelos setores ambientalistas, visando a busca de soluções para os problemas ambientais urbanos (ALBUQUERQUE \& LINO, 2007).

Os mosaicos também vêm enfrentando outros tipos de pressões que ameaçam seus objetivos de conservação, tais como: o estabelecimento da atividade de mineração em áreas protegidas e em seus entornos; a prática do turismo desordenado; a expansão da agropecuária tradicional, a exploração não sustentável dos recursos naturais, como por exemplo a exploração madeireira ilegal; a depredação do patrimônio histórico e cultural; a expansão da agricultura convencional, principalmente da monocultura de grãos; a pobreza; a prática da silvicultura; a introdução de espécies exóticas; o tráfico de animais silvestres, dentre outras. $\mathrm{Na}$ área do Mosaico do Espinhaço, Alto Jequitinhonha-Serra do Cabral, a silvicultura representa uma das mais significativas ameaças à conservação. $\mathrm{Na}$ área abarcada por este mosaico, as florestas plantadas de eucalipto são os ecossistemas predominantes. As florestas plantadas representam uma ameaça à conservação ambiental por requererem a supressão da vegetação nativa para seu plantio, resultando em empobrecimento da biodiversidade e na fragmentação dos habitats (AZEVEDO et al., 2009).

Os mosaicos foram criados a partir da iniciativa de atores diversos e dentro de contextos diversos. No entanto, na maioria dos casos, os mosaicos surgiram a partir da iniciativa conjunta de diversas instituições, como ONGs de cunho científico e ambientalista, órgãos governamentais, entidades da sociedade civil organizada, organismos multilaterais, dentre outras. Por exemplo, a criação do Mosaico do Espinhaço foi uma iniciativa do Instituto Biotrópicos de Pesquisa em Vida Silvestre, ONG dedicada à pesquisa científica e à conservação da natureza. 
Em 2005, o Instituto lançou o Projeto Espinhaço Sempre Vivo. O objetivo do projeto foi planejar um sistema de áreas protegidas que fosse representativo, ou seja, que abarcasse os diversos ecossistemas prioritários para a conservação existentes na região. O projeto traçou metas de criação de corredores ecológicos entre as UCs de proteção integral até o ano de 2035; de conservação dos remanescentes de vegetação nativa, das APPs e dos recursos hídricos; de preservação dos sítios arqueológicos e históricos da região; e de inclusão das comunidades rurais nos projetos de desenvolvimento sustentável e conservação. Visando alcançar tais objetivos, o Mosaico do Espinhaço foi criado sob a coordenação do Instituto Biotrópicos, em parceria com a Cl-Brasil, a Fundação Biodiversitas, o ICMbio, o Instituto Estadual de Florestas de Minas Gerais- IEF/MG, dentre outros parceiros (AZEVEDO et al., 2009).

O processo de criação do Mosaico Sertão-Veredas-Peruaçu também foi coordenado por uma ONG ambientalista, sendo esta a Fundação Pró-Natureza FUNATURA. Esta ONG participou do processo seletivo de projetos para a criação de mosaicos e elaboração de Planos de DTBC lançado pelo Edital FNMA no 01/2005, tendo sido a vencedora para implementar um projeto de criação de um mosaico na região dos Gerais, situada no Estado de Minas Gerais. A criação deste mosaico se deu a partir do estabelecimento de diretrizes de gestão integrada para UCs que já haviam sido criadas na região e que aderiram ao mosaico posteriormente. No entanto, a área que foi destinada ao Mosaico Sertão-Veredas-Peruaçu já era habitada por diversas comunidades locais que não participaram dos processos de criação das UCs da região. Esta defasagem ocorreu, em parte, porque na ocasião de criação dessas UCs ainda não era recomendada a ampla participação social no processo pela legislação ambiental brasileira. Mas, ainda assim esta metodologia de criação de UCs na região dos Gerais resultou em insatisfação social e hostilidade por parte da população local com relação às UCs recém criadas. Diante desta realidade excludente, a criação do Mosaico SertãoVeredas Peruaçu representou uma oportunidade para reverter a gestão de áreas protegidas realizada de cima para baixo, ao fomentar a ampla participação social na gestão pública ambiental. O Mosaico Sertão-Veredas Peruaçu foi o primeiro mosaico a ser criado no bioma Cerrado. Sua área é constituída por um conjunto variado de áreas protegidas que inclui UCs das categorias PARNA, APA, PAREST, RVS, RDS e RPPN, bem como por áreas protegidas do tipo APP, RL e Reserva Indígena (FUNATURA, 2014). 
Concluindo, os mosaicos não constituem um grupo homogêneo de blocos de áreas protegidas, tendo por base as mesmas características. Conforme descrito neste tópico, eles diferem entre si no que diz respeito aos contextos geográficos, biológicos, sociais e culturais nos quais estão inseridos. Por isso, cada um dos mosaicos que foram criados no Brasil até o momento atual apresenta suas próprias prioridades de conservação, bem como modos próprios de colocar em prática a gestão ambiental. Em outras palavras, não existe uma receita única que sirva para a totalidade dos mosaicos. São muitos os desafios a serem enfrentados pelos mosaicos para que possa ser garantido o sucesso na conservação, conforme já tratado neste tópico. Além do enfrentamento dos desafios já enumerados, os mosaicos devem estar articulados com as demais políticas públicas implementadas em sua região de abrangência, de modo que todos os setores, como os de educação, saúde, saneamento básico e transporte, possam convergir suas ações com os propósitos de conservação ambiental e de desenvolvimento sustentável planejados para a região.

\section{5- RELAÇÕES ENTRE FRAGMENTAÇÃO FLORESTAL E MOSAICOS DE ÁREAS PROTEGIDAS}

Fragmentação é o processo de separar o todo em partes. Os fragmentos são as novas partes geradas a partir da divisão do todo. A fragmentação florestal é a divisão de um dado habitat grande e contínuo em partes menores e isoladas entre si, denominadas fragmentos florestais ou fragmentos de habitats. A fragmentação florestal é produzida tanto por causas naturais como por causas antrópicas (BRITEZ et al., 2003).

Fatores naturais como variação climática, heterogeneidade de solos e de topografia, sedimentação, hidrodinâmica dos rios e mares e processos hidrogeológicos agem isoladamente ou combinados uns aos outros no ambiente ocasionando a fragmentação natural de habitats. A fragmentação florestal ocasionada por fatores naturais ocorre num período de tempo muitos mais longo do que a fragmentação florestal causada pela ação antrópica. A fragmentação natural é dinâmica e o isolamento de populações por ela produzido gera diferenciação genética e especiação, contribuindo, desta forma, para o incremento da diversidade biológica (BRITEZ et al., 2003).

A fragmentação florestal resultante da ação antrópica tem como característica principal a ocorrência em grande escala de espaço numa pequena escala de tempo. A 
intensificação do processo de fragmentação florestal por meio de ações antrópicas a torna um processo prejudicial à manutenção da biodiversidade (BRANT et al., 2003). A construção de estradas, o estabelecimento de cidades e de áreas agrícolas e de pastagens, a implantação de infraestrutura de energia e de saneamento, bem como a exploração de minérios correspondem a algumas das principais atividades antrópicas que ocasionam e intensificam a fragmentação florestal (PRIMACK \& RODRIGUES, 2001).

Os fragmentos de habitat que resultam do processo de fragmentação florestal ocasionado pela ação antrópica correspondem a áreas de habitat menores, se comparadas ao habitat contínuo anterior ao processo de fragmentação. Os novos fragmentos florestais irão encontrar-se distribuídos na paisagem de forma isolada uns dos outros, funcionando como verdadeiras ilhas de habitat dentro de uma matriz dominada pelas atividades humanas (PRIMACK \& RODRIGUES, 2001).

A matriz, anteriormente composta por habitats selvagens, passa a corresponder ao conjunto de áreas alteradas de diversas maneiras pela ação humana. Assim, a matriz poderá constituir-se de áreas de pastagem e de cultivos agrícolas, de florestas plantadas, de áreas urbanizadas, estradas e de demais tipos de habitats que foram alterados pela ação antrópica. A matriz corresponde à área circundante aos fragmentos florestais, compondo suas bordas (BARROS et al., 2006).

Os fragmentos de habitat resultantes da ação antrópica possuem uma área de borda mais ampla, se comparados ao habitat contínuo do qual se originaram. Além disso, os centros dos fragmentos situam-se mais próximos da área de borda, se comparado ao habitat contínuo originário. Esta característica torna os fragmentos mais suscetíveis aos efeitos de borda. Devido a estes dois fatores, os fragmentos de habitats são mais vulneráveis aos efeitos de borda que habitats grandes e contínuos. Na área da borda, o microambiente difere daquele que ocorre no interior do fragmento, ao qual diversas espécies de plantas e de animais estão adaptadas. As condições do microambiente da borda, tais como nível de luz, temperatura, humidade e vento exercem efeitos sobre $o$ interior dos fragmentos, alterando seu ambiente e, consequentemente, impactando sua biodiversidade (PRIMACK \& RODRIGUES, 2001).

Em razão das espécies de plantas e animais encontradas nos fragmentos serem adaptadas às condições ambientais que ocorrem na área dos fragmentos, muitas delas 
terão dificuldades em se adaptar às novas condições criadas pela influência do microambiente da área de borda. Geralmente, o microclima da área de borda é mais quente e seco. Assim, sua influência diminui a umidade e causa um aumento de temperatura no interior dos fragmentos. Estas novas condições irão dificultar a sobrevivência de espécies adaptadas a níveis de temperatura, umidade e luz característicos do habitat inalterado pela fragmentação, podendo até mesmo ocorrer a eliminação de determinadas espécies. Animais sensíveis à umidade, como os anfíbios, são frequentemente eliminados nos fragmentos devido aos efeitos de borda, ocasionando alteração na composição das espécies dos fragmentos (PRIMACK \& RODRIGUES, 2001).

Como na borda os ventos são mais intensos, a umidade reduzida e as temperaturas mais altas, a área proporciona as condições adequadas para a ocorrência de incêndios que, frequentemente, adentram as áreas dos fragmentos de habitat, impactando mais ainda sua biodiversidade. Além disso, a área de borda corresponde a um ambiente alterado onde espécies vegetais que comumente se desenvolvem em ambientes fortemente perturbados pela ação humana se estabelecem com mais facilidade, aumentando em número e invadindo o interior dos fragmentos (PRIMACK \& RODRIGUES, 2001).

As bordas também correspondem a ambientes adequados à sobrevivência de diversos animais onívoros, que podem aumentar em número nas áreas de borda. Estes animais, como por exemplo, o macaco-prego, ao aumentar sua população na área de borda, também irá utilizar os recursos encontrados no interior dos fragmentos para suprir suas necessidades de alimentação. No caso do macaco-prego, ocorre o consumo dos ovos e dos filhotes de pássaros da floresta, impedindo a reprodução bem-sucedida das aves (PRIMACK \& RODRIGUES, 2001).

As condições abióticas predominantes na borda, como a maior incidência de luz, favorecem o aumento da população de espécies características de áreas abertas. Em fragmentos de Floresta Amazônica, foi constatada uma invasão de borboletas típicas de áreas abertas. As borboletas que aumentaram em número na área de borda, adentraram os fragmentos em busca de alimento, gerando competição com as espécies de borboletas de sub-bosque típicas das áreas de floresta. A invasão das borboletas típicas de áreas abertas nos fragmentos causou também competição por locais de oviposição com as borboletas nativas, interferindo no comportamento reprodutivo das 
mesmas (BARROS et al., 2006). Assim, os efeitos de borda causam alteração na composição das espécies encontradas no interior dos fragmentos de habitat.

$\mathrm{Na}$ borda, a maior incidência de luz favorece o crescimento de vegetação pioneira. Este tipo de vegetação atrai espécies de animais folívoros e seus predadores, os quais irão interagir com as espécies presentes nos fragmentos. O declínio da população de aves em fragmentos de habitats decorre da invasão de predadores provenientes da área de borda. Assim, os efeitos de borda podem influenciar na interação entre as espécies e indiretamente nos processos ecológicos. No caso da diminuição do número de indivíduos de pássaros, poderá ocorrer, como consequência, alteração no padrão de dispersão de sementes. Esta alteração ocasionará transformações na composição de espécies vegetais nos fragmentos. Deste modo, os efeitos de borda nos fragmentos de habitat geram efeitos em cascata (BARROS et al., 2006).

Atualmente, o processo de fragmentação de habitat corresponde a uma das maiores ameaças à biodiversidade. Além dos efeitos de borda, a biodiversidade presente nos fragmentos é afetada pela perda de área e isolamento ocasionados pelo processo de fragmentação (BARROS et al., 2006). Fragmentos pequenos podem não possuir habitats suficientes para a sobrevivência de determinadas espécies, como por exemplo espécies que demandam grandes áreas para a sua manutenção. A redução do tamanho da área normalmente ocasiona maior competição entre as espécies pelos recursos necessários a sua sobrevivência, como alimentos e locais para a reprodução. Como consequência da intensificação da competição, algumas espécies irão migrar para outros fragmentos ou mesmo se extinguir localmente (ACACCIO et al., 2003).

Dependendo do tipo de matriz, algumas espécies irão encontrar-se completamente isoladas na área do fragmento, uma vez que estarão impossibilitadas de transpor a área da matriz devido às suas características de adaptação. A impossibilidade de transposição da matriz reduz ou mesmo elimina o fluxo gênico de determinadas espécies presentes no fragmento. Os processos de colonização por espécies provenientes de áreas vizinhas impedem que espécies presentes no fragmento acessem recursos localizados em outras manchas de habitat necessários à sobrevivência. O pequeno tamanho populacional de determinadas espécies associado à redução do fluxo gênico, em razão do isolamento decorrente do processo de fragmentação, resulta em depressão endogâmica, que é uma consequência do 
endocruzamento - cruzamento entre poucos indivíduos da espécie. A depressão endogâmica resultante do endocruzamento leva à redução da variabilidade genética no nível da espécie. Esta redução da variabilidade genética compromete a capacidade de persistência das espécies, uma vez que ocasiona a perda da flexibilidade evolutiva, comprometendo o sucesso adaptativo das espécies (BARROS et al., 2006). Deste modo, a persistência de determinadas populações em paisagens fragmentadas depende essencialmente da existência de conectividade entre os fragmentos de habitat (ACCACIO et al., 2003; BARROS et al., 2006).

Os mosaicos de áreas protegidas predominam no Bioma Mata Atlântica, onde a paisagem apresenta alto grau de fragmentação. Neste bioma, é papel dos mosaicos contribuir para a reversão deste cenário. A gestão integrada proposta pelo modelo de mosaico se apresenta como uma possibilidade de união de forças políticas em prol da conservação. Este incremento da força política nos mosaicos poderá resultar na criação e implantação de instrumentos de conservação da biodiversidade, como os corredores ecológicos, que servem de faixa de conectividade entre os fragmentos de habitat nas áreas abarcadas pelos mosaicos.

No Bioma Floresta Amazônica, onde o grau de fragmentação de habitats não é tão significativo quanto na Mata Atlântica, os mosaicos se apresentam como instrumentos de prevenção aos processos de fragmentação florestal. No Mosaico do Baixo Rio Negro- MBRN, objeto do estudo de caso da presente pesquisa, a gestão integrada que nele busca-se praticar nele praticada resultou no advento de uma força política significativa que atua em prol da conservação da biodiversidade da região.

No MBRN, a força política conjunta, que envolve diversas instituições, de naturezas distintas e oriundas de esferas de poderes diversos, vem atuando de forma a impedir processos de degradação ambiental na região que consequentemente resultariam em processos de fragmentação florestal, como é o caso da atividade mineradora na região do PAREST Setor Norte, UC componente do Mosaico. Neste caso específico, o Conselho do Consultivo uniu forças para solicitar ao Ministério Público o impedimento da abertura de novas áreas para a mineração dentro desta UC. Ao analisar este contexto, depreende-se que o MBRN representa uma potencialidade para a prevenção da ocorrência de novos processos de fragmentação florestal na região onde está situado. 


\section{CAPÍTULO 3- A CRIAÇÃO DO MOSAICO DO BAIXO RIO NEGRO: UNINDO PEÇAS PARA A CONSERVAÇÃO}

\section{1- AS UCs DO MOSAICO DO BAIXO RIO NEGRO: DIVERSIDADE E UNIDADE NO}

TERRITÓRIO

O Mosaico de Áreas Protegidas do Baixo Rio Negro abrange uma área de aproximadamente 7.292.113 hectares, localizada na região do Baixo Rio Negro, Estado do Amazonas. O Mosaico é formado por doze UCs, sendo elas: RESEX do Rio Unini, RDS Amanã, RDS Puranga-Conquista, RDS Rio Negro, RDS Tupé, PARNA do Jaú, PARNA de Anavilhanas, PAREST Rio Negro Setor Norte, PAREST Rio Negro Setor Sul, APA Margem Direita do Rio Negro, APA Margem Esquerda do Rio Negro Setor Aturiá e APA Margem Esquerda do Rio Negro Setor Tarumã-Açu (FVA, 2011; SISUC, 2014).

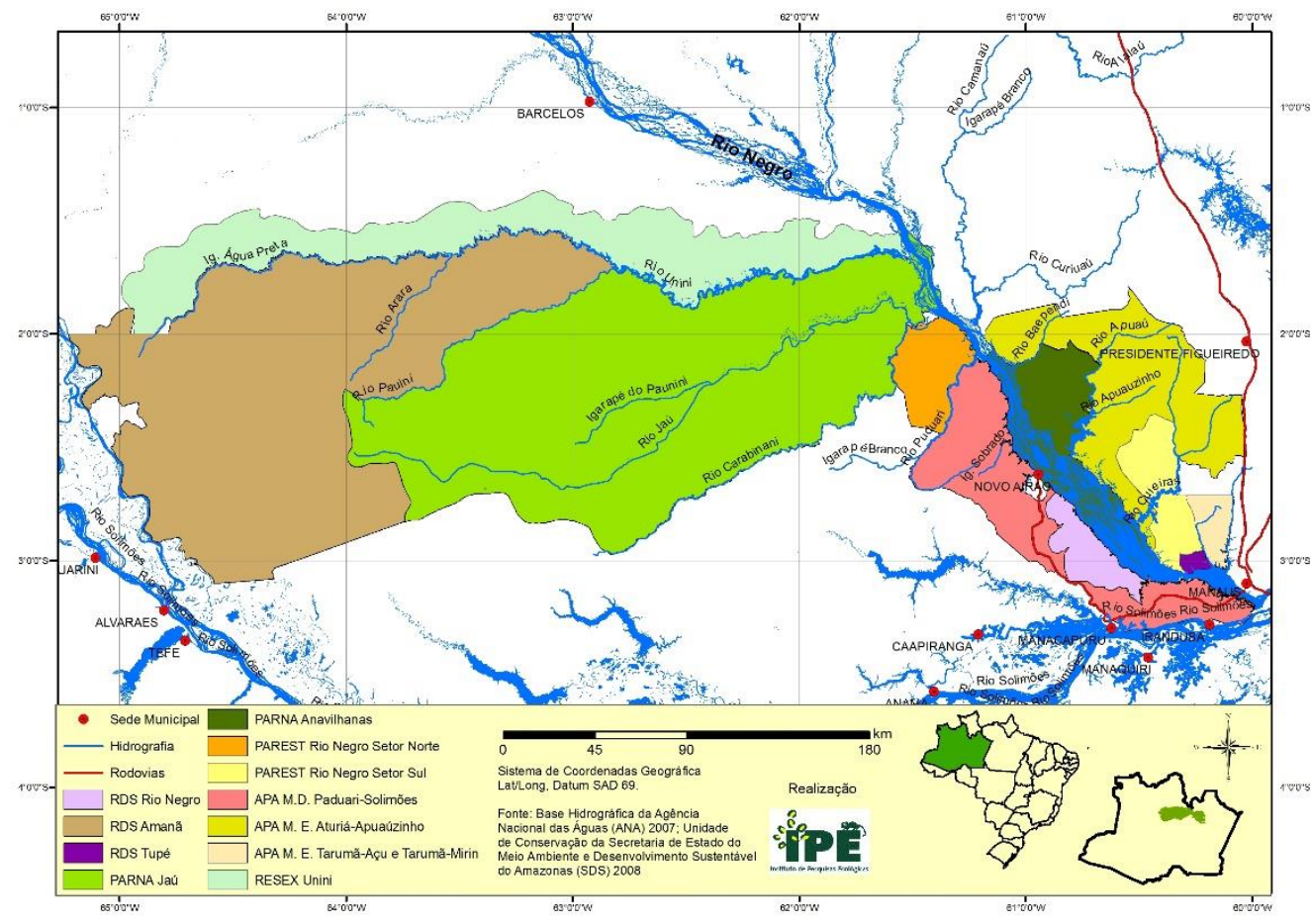

Ilustração 1- Mapa do Mosaico do Baixo Rio Negro (anterior à criação da RDS Puranga Conquista). Autor: Desconhecido. Fonte: www.ipe.org.br.

Segundo a Portaria MMA № 483, de 14 de dezembro de 2010, que reconhece 0 Mosaico de Áreas Protegidas do Baixo Rio Negro, as UCs que o constituem pertencem às categorias de proteção integral e de uso sustentável previstas no SNUC. Os PARNAs do Jaú e de Anavilhanas, e os PARESTs do Rio Negro Setor Sul e do Rio Negro Setor Norte correspondem às UCs de proteção integral que formam o Mosaico. As demais UCs que integram o Mosaico pertencem à categoria de uso sustentável. Conforme a 
Portaria № 483, as UCs que compõem o Mosaico do Baixo Rio Negro estão sob a gestão das esferas de poder federal, estadual e municipal, além da gestão executada pelos Conselhos de cada uma das UCs. As UCs PARNA do Jaú, PARNA de Anavilhanas e RESEX do Rio Unini são geridas pelo poder federal, pelo ICMbio. O PAREST Rio Negro Setor Sul, o PAREST Rio Negro Setor Norte, as APAs Margem Direita do Rio Negro, Margem Esquerda do Rio Negro Setor Aturiá e Margem Esquerda do Rio Negro Setor Tarumã-Açu, a RDS do Rio Negro e a RDS do Amanã são geridas pelo poder estadual, pela Secretaria de Estado do Meio Ambiente e Desenvolvimento Sustentável do Estado do Amazonas. A RDS do Tupé é gerida pelo poder municipal, pela Secretaria Municipal de Meio Ambiente da Prefeitura de Manaus.

\section{2- AS UNIDADES DE PROTEÇÃO INTEGRAL}

As UCs de proteção integral do Mosaico do Baixo Rio Negro, como vimo, são todas parques, nacionais ou estaduais. Os Parques, segundo o SNUC, têm por objetivo preservar ecossistemas de grande relevância ecológica e significativa beleza cênica, sendo permitido apenas o uso indireto dos recursos naturais. Deste modo, somente atividades de pesquisa científica, educação ambiental, recreação e turismo ecológico são permitidas nos Parques. Fazem parte do Mosaico do Baixo Rio Negro as UCs de proteção integral: PARNA do Jaú, PARNA de Anavilhanas e os PARESTs Rio Negro Setor Norte e Rio Negro Setor Sul.

Durante a década de 1980, principalmente na Amazônia, as UCs de proteção integral foram criadas para atender medidas de compensação ambiental de grandes empreendimentos desenvolvimentistas. Tais UCs foram criadas em áreas de pouca relevância econômica e fizeram parte da estratégia geopolítica do governo de ocupar áreas na Amazônia por meio de projetos de colonização. O PARNA de Anavilhanas constitui um bom exemplo de UC criada dentro deste contexto, na década de 1980 (CARDOSO et al., 2008).

\subsection{1- O PARNA DE ANAVILHANAS}

Abrangendo uma área equivalente a 350.018 hectares, o PARNA de Anavilhanas foi criado em 1981, inicialmente como uma Estação Ecológica- ESEC. A criação desta UC fez parte das estratégias traçadas no II Plano Nacional de Desenvolvimento - PND - do Governo Federal. Em 2008, a ESEC de Anavilhanas foi 
recategorizada, transformando-se em Parque Nacional. A recategorização ocorreu em razão da necessidade de atender a significativa demanda turística oriunda da região de Manaus. Desta forma, os principais objetivos da UC passaram a ser: proteger o arquipélago fluvial formado por cerca de quatrocentas ilhas, em conjunto com suas diversas formações florestais, promover a pesquisa científica, a educação ambiental e o turismo de base sustentável (CARDOSO et al., 2008; Mapa Turístico de Anavilhanas, 2014).

O PARNA de Anavilhanas está localizado na região do baixo rio negro, no Estado do Amazonas. Entende-se por baixo rio negro o trecho de rio que parte do município de Barcelos, terminando junto à foz próxima a Manaus (LEONARDI,1999). O Parque abrange os municípios de Manaus e Novo Airão. A sua área é ocupada exclusivamente por formações florestais pertencentes ao Bioma Floresta Amazônica, como a Floresta de Igapó, a Floresta Densa de Terra Firme, as Campinas e Campinaranas, a Caatingagapó, o Chavascal, além dos ecossistemas fluviais e lacustres. $O$ arquipélago de Anavilhanas é formado pelos rios amazônicos de água preta. As bacias e rios amazônicos de água preta são conhecidos na região como "rios da fome". Este nome é atribuído a esses rios em razão da dinâmica de seus ciclos hidrológicos, marcada por períodos alternados de seca e de alagamentos e também em razão das condições oligotróficas das águas pretas, caracterizadas por baixos níveis de nutrientes e baixa produtividade de biomassa (Mapa Turístico de Anavilhanas, 2014).

O PARNA de Anavilhanas é uma das poucas UCs do Brasil com situação fundiária regularizada. As terras que compõem a área do Parque foram cedidas pelos governos federal e estadual ao IBAMA quando da criação da ESEC, em 1981. Apesar da categoria de Parque Nacional, UC de proteção integral, a biodiversidade de Anavilhanas sofre ameaças constantes, como a pesca, a caça e a extração madeireira ilegal, o tráfego desordenado de embarcações fluviais, a prática do turismo predatório, a invasão de suas terras por grileiros e a prática ilegal da mineração dentro da UC. Anavilhanas vem sofrendo forte pressão de mineradoras interessadas na extração de cascalho e areia de suas praias fluviais (ISA, 2014).

O PARNA de Anavilhanas encontra-se sob a administração do ICMbio e do Conselho Consultivo da UC. O Conselho foi criado em 2006, anteriormente à recategorização da UC para Parque Nacional, porém muito tempo depois da criação da UC em 1981. O Conselho Consultivo da UC possui natureza multisetorial, dele 
participando representantes do governo, de ONGs, de comunidades ribeirinhas, do setor privado, dentre outros atores atuantes na região abarcada pelo Parque. A formação do Conselho Consultivo da UC é uma medida atual compensatória da falta de participação da população local quando da criação da UC em 1981 (CARDOSO et al., 2008).

O PARNA de Anavilhanas foi contemplado pelo Programa Parques da Copa, do Ministério do Turismo. O Parque recebeu, por meio do Programa, um recurso de quinhentos mil reais para investimentos em obras de sinalização e ordenamento da hidrovia, com a finalidade de atrair o turismo na época da Copa do Mundo. O Parque foi o principal alvo do Programa Parques da Copa, que inicialmente pretendia investir 668 milhões de reais na infraestrutura de vinte e três Parques Nacionais. Porém, apenas um milhão de reais foi efetivamente empenhado para a melhoria dos Parques por meio do Programa do Ministério do Turismo. O PARNA de Anavilhanas e o PARNA de Itatiaia, localizado no estado do Rio de Janeiro, receberam cada, metade da verba que foi empenhada (ISA, 2014). Esta realidade traduz a pouca importância dada pelo Governo Federal ao turismo de base sustentável.

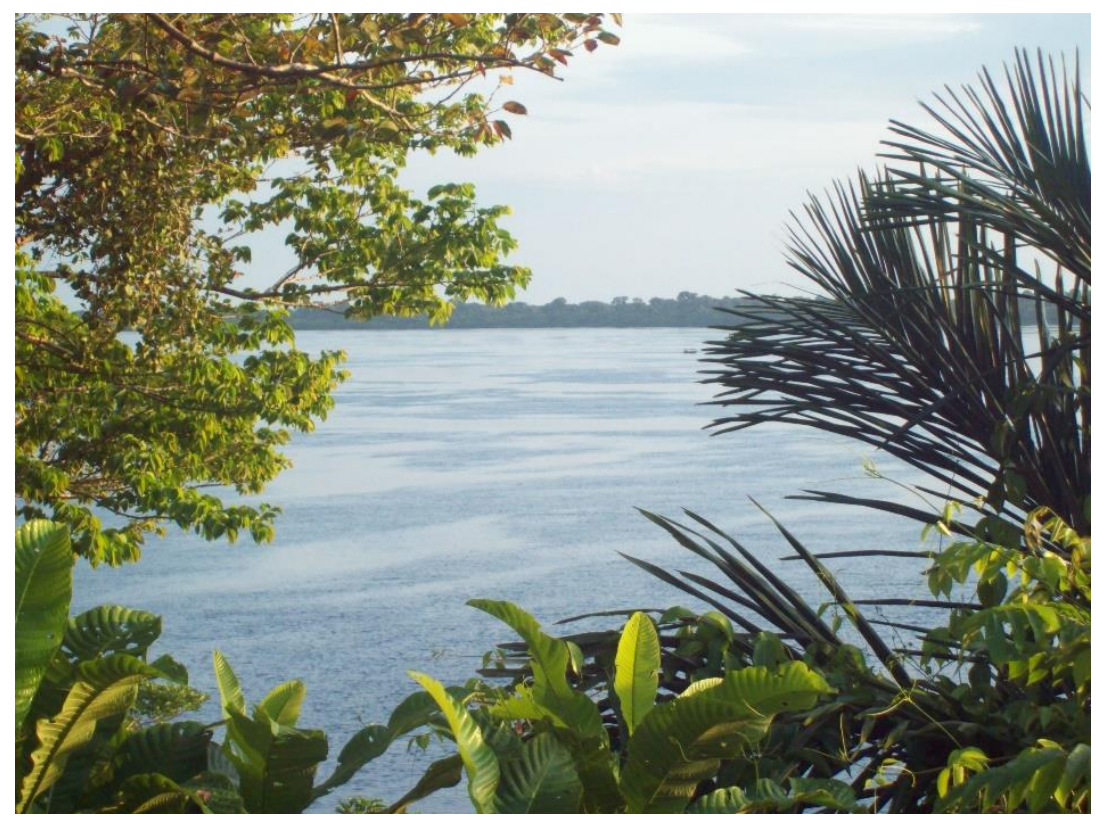

Ilustração 2- PARNA de Anavilhanas. Novo Airão/AM. Autor: Carolina Azevedo. Agosto/2014.

\subsection{2- O PARNA DO JAÚ}

O Parque Nacional do Jaú- PNJ - foi criado em 1980, e abrange uma área de cerca de 2.272.000 hectares, sendo uma das mais extensas UCs já criadas no Brasil. O 
PNJ está localizado na margem direita do Rio Negro, na Bacia do Rio Jaú, a 220 quilômetros a noroeste de Manaus. A margem direita do Parque é banhada pelo Rio Unini e a esquerda pelo Rio Carabinani. O PNJ é a única UC que protege integralmente uma Bacia Hidrográfica. No caso específico, trata-se da Bacia do Rio Jaú (ISA, 2014). De acordo com o Decreto № 85.200, de 24 de setembro de 1980, que criou o Parque, é finalidade desta UC preservar integralmente os ecossistemas naturais englobados dentro de seus limites, promover a pesquisa científica, a educação ambiental e o turismo de base sustentável.

O PNJ abriga uma variedade de formações florestais características do Bioma Floresta Amazônica, tais como: Floresta de Igapó, Campinaranas e Buritizal. O Parque possui uma vegetação bastante diversa, com ocorrência de espécies endêmicas, ou seja, de grupos taxonômicos que se desenvolvem de modo restrito à determinada região. O PNJ também abriga uma fauna bastante biodiversa. A maior parte da ictiofauna da Bacia do Rio Negro ocorre nas águas do Parque. Além disso, seus rios e lagos produzem uma grande quantidade de algas, as quais são a base alimentar para diversas espécies de aves, peixes e mamíferos da região (ISA, 2014).

De acordo com o Instituto Socioambiental, a regularização fundiária é um dos desafios do PNJ, pois dentro de seus limites ainda existem parcelas de terras sob domínio de particulares e áreas de posse ocupadas por moradores que vivem da pesca, agricultura de subsistência e do extrativismo. Além da regularização fundiária, a pesca, a caça e a extração de madeira ilegal, bem como o turismo predatório, são ameaças aos objetivos de proteção à biodiversidade do PNJ. A fiscalização do Parque tem enfrentado sérios problemas relacionados ao comércio ilegal de produtos da fauna nativa praticado por moradores e invasores. Os principais produtos comercializados de forma ilegal, oriundos do PNJ são as carnes do pirarucu (Arapaima gigas), da anta (Tapirus terrestris) e do mamífero queixada (Tayassu pecari), além dos quelônios e de espécies de peixes ornamentais, como por exemplo o filhote de aruanã (Osteoglossum bicirrhosum) (DRUMMOND \& FRANCO, 2009).

Numa tentativa de conciliar preservação ambiental e uso dos recursos naturais pelas populações humanas residentes do PNJ, foram assinados sessenta e um Termos de Compromisso - TC - entre seus moradores e o ICMbio. O objetivo dos TCs consiste em ajustar as obrigações de ambas as partes, assim como disciplinar o uso dos recursos 
naturais disponíveis no PNJ, de modo que a exploração ocorra de modo sustentável (ISA, 2014).

Desde a criação do PNJ, o principal problema enfrentado tem sido a presença de populações humanas dentro de sua área de abrangência. O PNJ foi criado em 1980, porém apenas a partir 1985 é que foram tomadas medidas mais efetivas pelo Instituto Brasileiro de Desenvolvimento Florestal- IBDF e pelo Instituto de Terras do Amazonas - ITEAM para a consolidação do Parque. Dentre tais medidas, destacaram-se a realização de estudos sobre a situação fundiária das áreas do Parque e o levantamento das populações humanas que nele residiam (DRUMMOND \& FRANCO, 2009).

A partir de 1989, o recém criado IBAMA tornou-se o responsável pela gestão do Parque. Em 1993, a ONG Fundação Vitória Amazônica - FVA firmou uma parceria com o IBAMA para compartilhar as atividades de gestão do Parque. Esta parceria resultou na construção do Plano de Manejo do PNJ, aprovado em 1998. A FVA também foi responsável pelo desenvolvimento do projeto "Janelas para a Biodiversidade". O principal objetivo do projeto consistiu em inventariar, monitorar e divulgar informações acerca da biodiversidade do PNJ, além de realizar um levantamento das populações residentes em sua área (DRUMMOND \& FRANCO, 2009).

A presença de populações humanas na área que hoje pertence ao PNJ é bastante antiga. Foram encontrados na região vestígios arqueológicos datados de 880 a 1.560 anos D.C que comprovam a ocorrência de presença humana. Mas, foi apenas a partir do ciclo econômico da borracha, iniciado no final do século XIX, que a população da região obteve um adensamento significativo. Visando a exploração da borracha para abastecer as indústrias automobilísticas incipientes dos Estados Unidos e Europa, os seringalistas instalaram núcleos familiares nos vales dos rios Jaú, Carabinani e Unini. Essas famílias se dedicavam basicamente à extração do látex da seringueira nativa Hevea brasiliensis, abundante na região. Durante este período histórico, o movimento migratório para os vales dos rios Jaú, Carabinani e Unini foi tão intenso que atualmente é compreendido como uma das mais significativas transferências de populações humanas já ocorridas em território brasileiro (DRUMMOND \& FRANCO, 2009).

Antes mesmo da chegada dos portugueses, a região do Baixo Rio Negro já encontrava-se ocupada por diversos povos autóctones, como os índios Manau, Baré e Tarumã. Alguns desses povos indígenas, como o povo Manau, foram levados à 
completa extinção devido à imposição de práticas missionárias levadas para a região pelos colonizadores portugueses. Na região do baixo rio negro, os indígenas foram aldeados por missionários mercedários e carmelitas, a partir do século XVII. Com o fim do sistema de aldeamento, os tapuios - tapuio é a denominação dada aos remanescentes de povos indígenas que foram aldeados por missionários portugueses se estabeleceram nas margens distantes dos rios do baixo rio negro. A maior parte dos migrantes que ocuparam os vales dos rios Jaú, Carabinani e Unini eram originários da Região Nordeste. O resultado desta migração de nordestinos para a Região Norte foi a miscigenação. A nova população de nordestinos, recém chegada na região do Baixo Rio Negro, miscigenou-se com as populações de "tapuios" que já residiam no local (LEONARDI, 1999).

Com o declínio definitivo da economia da borracha no fim da década de 1940, a densidade populacional na região do baixo rio negro diminuiu. No entanto, uma parcela da população optou por permanecer no local, residindo na área do PNJ até os dias de hoje. De acordo com a categorização dos assentamentos humanos do PNJ elaborada pela FVA, residem no Parque populações consolidadas em comunidades e localidades. As comunidades são grupos de famílias que vivem na região, dispondo de alguns serviços comunitários, como escolas e postos de saúde. Já as localidades referem-se a agrupamentos de casas, localizados ao longo das margens dos rios que banham o PNJ, mas que não dispõem de serviços comunitários (DRUMMOND \& FRANCO, 2009).

O PNJ também lida com o problema da "invenção de um quilombo" na Comunidade do Tambor. Os moradores dessa comunidade se auto declaram remanescentes de quilombo, demandando o reconhecimento do território quilombola dentro da área da UC de proteção integral (DRUMMOND \& FRANCO, 2009). As pesquisas realizadas pelo historiador Victor Leonardi (1999) sobre a história social e ambiental da região do Baixo Rio Negro, no entanto, demonstraram que:

\footnotetext{
Não ocorreu, no Jaú, nada semelhante ao que ocorreu no Rio Trombetas, onde de fato surgiram quilombos amazônicos negros. Quanto aos negros que atualmente moram no lugar chamado Tambor, no vale do Jaú, imediações do rio Pauini, não são descendentes de quilombolas, nem dos dois únicos escravos negros de que se tem notícia na Airão do século XIX, mas sim de um casal de imigrantes negros, sergipanos, que vieram para o Jaú no início do século XX, por volta de 1910. Ele chamava-se Jacinto Francisco de Almeida, e ela, Dona Leopoldina. (p. 110).
}

Para Drummond e Franco (2009), a invenção de um quilombo na área do PNJ consiste na "arte de semear conflitos socioambientais". Segundo os autores, não há 
fatos novos que contrariem as constatações de Leonardi. Sendo assim, a invenção do Quilombo do Tambor permanece uma ameaça aos objetivos de conservação traçados para o PNJ. Segundo os autores, os moradores do Tambor devem ser compensados financeiramente, como é o desejo da quase totalidade deles e devidamente realocados em localidades próximas do PNJ, como por exemplo Novo Airão.

\subsection{3- O PAREST RIO NEGRO SETOR NORTE}

O PAREST Rio Negro Setor Norte foi criado em 1995, abrangendo uma área de 146.028 hectares. O Parque é uma UC estadual gerida pela Secretaria Estadual de Meio Ambiente e Desenvolvimento Sustentável do Estado do Amazonas- SDS. O Conselho Consultivo do Parque também administra a UC. Formado apenas em 2008, oito anos após a criação do Parque, o Conselho Consultivo é multisetorial, dele participando representantes do governo, de associações, de ONGs e de moradores (ISA, 2014).

Segundo o Instituto Socioambiental, o PAREST Rio Negro Setor Norte apresenta formação florestal diversificada, com predominância das Matas de lgapó e ocorrência de Campinaranas e Matas de Terra Firme. No Parque, ocorrem espécies florísticas de significativo valor econômico, como o cipó-titica e a itaúba. A biodiversidade que ocorre na área do Parque é rica quanto à ictiofauna, variedade de insetos e aves, incluindo espécies de interesse econômico, como o pirarucu (Arapaima gigas). Há ocorrência de espécies raras entre as aves, como o Nothocrax urumutum, pequena espécie de mutum amazônico.

Residem nos arredores do Parque diversas comunidades. As principais atividades desenvolvidas por essas comunidades são a agricultura de subsistência e o extrativismo. Dentre os recursos naturais do Parque explorados pela atividade extrativista, destacam-se o cipó-titica, o cipó- timbó, a copaíba, a sorva, a seringa e a piaçava. O PAREST Rio Negro Setor Norte limita-se com o PNJ e é parte integrante do Corredor Ecológico Central da Amazônia e da Reserva da Biosfera da Amazônia Central. Apesar de criado em 1995, o Parque ainda não possui Plano de Manejo. No entanto, a biodiversidade do Parque enfrenta ameaças constantes, como a exploração ilegal de madeira, a mineração e o tráfico de animais silvestres (ISA, 2014). 


\subsection{4- O PAREST RIO NEGRO SETOR SUL}

O PAREST do Rio Negro Setor Sul foi criado em 1995, por meio do Decreto Estadual № 16.497. Fatores políticos foram a principal motivação para a criação do Parque. Sua área inicial equivalia a 257.422 hectares. No entanto, a área destinada a esta UC de proteção integral vem sendo objeto de reduções constantes. Em maio de 2001, a Lei Estadual № 2.646 reduziu a área do Parque para 157.807 hectares e, em 24 de março de 2014, outra Lei Estadual- Lei o 4015- reduziu ainda mais a área do Parque, visando a criação da mais recente UC de uso sustentável componente do Mosaico, a RDS Puranga Conquista. Atualmente, o Parque abrange uma área de cerca de 86.601 hectares e a criação da RDS Puranga Conquista se deve ao fato da não inclusão dos moradores do Parque nos debates que culminaram na criação e implementação da UC. A maior parte dos moradores pertencem a grupos indígenas e comunidades ribeirinhas que se auto identificam como tradicionais (ISA, 2014).

Conforme entendimento do ISA, além de não terem participado dos debates para a criação do Parque, os moradores apenas tomaram conhecimento sobre as restrições de uso que recaíram sobre a área em 2003, em razão das expedições realizadas no local pelo Instituto de Pesquisas Ecológicas - IPÊ. A imposição de políticas fundiárias de cima para baixo propiciou o surgimento de conflitos socioambientais na região do Parque, culminando na redelimitação e recategorização da UC, com a criação da RDS Puranga Conquista.

Assim como o PAREST Rio Negro Setor Norte, o PAREST Rio Negro Setor Sul está inserido no Corredor Ecológico Central da Amazônia e na Reserva da Biosfera da Amazônia Central. A área protegida pelo Parque engloba as bacias hidrográficas do Rio Cuieiras e do Rio Tarumã- Mirim. As principais formações florestais com ocorrência na área do Parque são a Floresta de Igapó, a Floresta Densa de Terra Firme, a Campina e a Campinarana. A biodiversidade presente no Parque é rica e diversificada, com ocorrência de espécies endêmicas, como o primata comumente conhecido como Sauim-de-Coleira (Sanginus bicolor) (ISA, 2014).

O PAREST Rio Negro Setor Sul está localizado nas proximidades de Manaus, a apenas 40 quilômetros de distância da capital amazonense. Devido a esta localização, é objetivo do Parque a contenção do crescimento populacional de Manaus. Atualmente, o Parque é administrado pelo Instituto de Proteção Ambiental do Estado do Amazonas 
- IPAAM - e pela SDS. O principal problema enfrentado pela gestão do PAREST Rio Negro Setor Sul consiste na sobreposição de políticas fundiárias divergentes dentro de seus limites. Há um excesso de ações de ordenamento do território na área abrangida pelo Parque. Este excesso de ordenamento resultou em conflitos entre instâncias e órgãos governamentais, entre comunidades locais e governo e entre os moradores do Parque. Este cenário de conflitos dificulta a implementação de ações de conservação e desenvolvimento sustentável na área do Parque (CARDOSO et al., 2008).

No PAREST do Rio Negro Setor Sul, o excesso de ordenamento ocorreu de diversas formas. Uma delas foi a sobreposição do Parque com áreas destinadas ao controle estratégico do Governo Federal, visto que o Parque encontra-se sobreposto a uma área de treino da Polícia Federal - PF e a uma área de trabalho da Marinha brasileira. Outro excesso de ordenamento do território que ocorre na área do Parque é a sobreposição deste com o Projeto de Assentamento (PA) Cuieiras-Anavilhanas, criado pelo Instituto Nacional de Colonização e Reforma Agrária - INCRA, em 2005, com vistas a atender reivindicações de comunidades ribeirinhas locais (CARDOSO et al., 2008). De acordo com Illenseer, gestor da FUNAI, anteriormente consultor do IPÊ e participante ativo no processo de criação do Mosaico do Baixo Rio Negro e atualmente membro convidado do Conselho Consultivo do Mosaico:

Ocorrem conflitos entre os objetivos de proteção integral do Parque e moradores que se identificam como territorialidades indígenas de etnias variadas e que atualmente residem dentro dos limites da UC. A demanda já está expressa na ação governamental relativa à identificação da Terra Indígena Rio Cuieiras (informação verbal). ${ }^{4}$

${ }^{4}$ Entrevista concedida em 01 de agosto de 2014, em Novo Airão- Amazonas. 
De acordo com o Decreto № 1775/96 que regulamenta o processo de demarcação de $\mathrm{TI}$, a identificação é o primeiro passo do processo. Conforme a Fundação Nacional do Índio- FUNAI, esta etapa inicial demanda estudos de identificação e delimitação a seu cargo, sendo pré-requisito para as demais etapas do processo que culmina no registro da TI na Secretaria de Patrimônio da União. Caso a TI Rio Cuieiras seja reconhecida, a área destinada ao Parque será redelimitada. Assim, as "peças" que fazem parte do Mosaico do Baixo Rio Negro encontram-se em processo de definição quanto a sua função na conservação da biodiversidade.

Ainda conforme Illenseer,

Além da reivindicação pela identificação da TI Rio Cuieiras, localizada dentro dos limites do PAREST do Rio Negro Setor Sul, a etnia Waimiri-Atroari também reivindica uma ampliação de sua Terra Indígena. Esta TI situa-se no entorno do Mosaico do Baixo Rio Negro, dele não fazendo parte oficialmente. A demanda dos índios Waimiri- Atroari, caso seja atendida, poderá promover mudanças no Mosaico quanto à categoria e dimensão das áreas protegidas que o compõem, redefinindo suas peças e portanto o funcionamento de seu todo (informação verbal). ${ }^{5}$

Nos termos da Constituição Federal de 1988, Capítulo VIII - Dos Índios, Artigo 231, Parágrafo $1^{\circ}$, as Terras Indígenas correspondem a:

Terras tradicionalmente ocupadas pelos índios em caráter permanente, utilizadas para suas atividades produtivas, sendo imprescindíveis à preservação dos recursos ambientais necessários a seu bem-estar e a sua reprodução física e cultural, segundo seus usos, costumes e tradição (BRASIL, 1988).

Ainda conforme a o Artigo 231 da Constituição Federal:

São reconhecidos aos índios sua organização social, costumes, línguas, crenças e tradições e os direitos originários sobre as terras que tradicionalmente ocupam, competindo à União demarcá-las, proteger e fazer respeitar todos os seus bens (BRASIL, 1988).

${ }^{5}$ Entrevista concedida em 01 de agosto de 2014, em Novo Airão- Amazonas. 
De acordo a FUNAI, baseado na interpretação do Artigo 231 da Constituição Federal, o direito dos povos indígenas às terras que tradicionalmente ocupam é um direito originário e, por esta razão, o procedimento administrativo para o reconhecimento de TI é de natureza declaratória, sendo esta então reconhecida e não "criada". Ademais, os direitos sobre as Terras Indígenas não estão sujeitos à prescrição. As Tls pertencem à União, sendo, portanto, inalienáveis.

Conforme a FUNAI, atualmente existem no Brasil 462 Tls regularizadas, cobrindo aproximadamente $12,2 \%$ de todo o território nacional. Localizadas nos diversos biomas e regiões brasileiras, as Tls concentram-se na Região Norte, onde estão 54\% do total das Tls regularizadas no Brasil. O Amazonas é o estado que tem o maior número de Tls. Aproximadamente $30 \%$ das Tls que contam com regularização fundiária localizam-se no Estado do Amazonas. Estas cobrem cerca de 45.736.118 hectares da superfície total do estado, o equivalente a $26,8 \%$ de sua área total.

As Terras Indígenas são consideradas áreas protegidas pelo Decreto № 5.758, que instituiu o Plano Estratégico Nacional de Áreas Protegidas - PNAP. Portanto, à luz da definição da IUCN de área protegida, as TIs correspondem a espaços geográficos delimitados com base em instrumentos legais ou outros igualmente eficientes, cuja finalidade é conservar a natureza ao longo do tempo, além de preservar os serviços associados ao ecossistema e os valores culturais nele inseridos. Assim, os objetivos da TI são compatíveis com os objetivos do mosaico de áreas protegidas, quais sejam compatibilizar a presença da biodiversidade com a valorização da sociodiversidade, preservando os ecossistemas e as culturas.

Desde 2012, as ações de gestão ambiental em Terras Indígenas são norteadas pela Política Nacional de Gestão Territorial e Ambiental de Terras Indígenas - PNGATI. O objetivo da PNGATI é promover a proteção, recuperação, conservação e o uso sustentável dos recursos naturais nas Terras e Territórios Indígenas. Com isto, a PNGATI visa assegurar a integridade do patrimônio indígena, a melhoria da qualidade de vida e sua reprodução física e cultural. A PNGATI prevê a elaboração e implementação de Planos de Gestão Territorial e Ambiental em Terras IndígenasPGTAs (FUNAI, 2014).

O PGTA tem como objetivo o planejamento da gestão para as TIs. No PGTA devem ser considerados aspectos como: o diálogo intercultural, a promoção da participação indígena nas políticas públicas socioambientais, a articulação com órgãos 
ambientais das esferas de poder federal, estadual e municipal, visando promover a interface com as demais áreas protegidas, a capacitação para a formação de gestores indígenas, mecanismos de apoio à implementação de sistemas de pagamentos por serviços ambientais, bem como o apoio a projetos que visem a conservação da biodiversidade e a recuperação ambiental de áreas degradadas (FUNAI, 2014).

As demandas pela ampliação da TI Waimiri-Atroari e pela identificação da TI Rio Cuieiras, caso atendidas, irão promover mudanças no Mosaico do Baixo Rio Negro. Estas mudanças são relativas à dimensão geográfica e tipos de áreas protegidas que o compõem. Isto porque as TIs também fazem parte do rol das áreas protegidas, sendo um de seus principais objetivos a conservação da biodiversidade. Atualmente, o direito ambiental brasileiro exige que a gestão das TIs seja praticada com observância de suas regras. Um exemplo deste contexto é a PNGATI, mencionada acima. O maior desafio consiste em assegurar a gestão compartilhada do Mosaico, frente a um cenário de ampliação dos atores envolvidos em sua administração.

Concluindo, as UCs de proteção integral que compõem o Mosaico do Baixo Rio Negro formam uma área que cobre aproximadamente 2.854.647 hectares de Floresta Amazônica, formando um grupo de quatro UCs na categoria de Parque. Como a área total do Mosaico é de cerca de 7.292.113 hectares, as UCs de proteção integral que dele fazem parte representam aproximadamente $39 \%$ de sua área. As UCs de uso sustentável predominam no Mosaico, somando um total de oito UCs, que cobrem uma área de aproximadamente 4.437 .466 hectares, que representa cerca de $61 \%$ da área total do Mosaico.

As UCs de uso sustentável do Mosaico do Baixo Rio Negro, assim como as de proteção integral, devem articular-se com as políticas públicas de desenvolvimento implementadas na região. Esta articulação é importante para garantir sucesso para o projeto de desenvolvimento sustentável planejado para as unidades. A RESEX Chico Mendes, criada na década de 1990, no Estado do Acre, consiste num caso ilustrativo de colapso de UC de uso sustentável, em razão de deficiências no campo das articulações com políticas públicas de desenvolvimento (DRUMMOND \& FRANCO, 2009).

Para os autores, a situação atual da RESEX Chico Mendes é precária. O desmatamento de áreas florestais para o estabelecimento da pecuária aumentou significativamente na RESEX. Dados provenientes do cadastro de vacinação do gado 
bovino de 2008 comprovaram a existência de um rebanho de cerca de dez mil cabeças dentro dos limites da UC. Além dessa, foram constatadas outras incongruências na RESEX Chico Mendes, tais como: instalação de um haras privado, arrendamento e venda de colocações para pecuaristas pelos seringueiros e fracionamento das colocações para o estabelecimento de áreas de lazer.

A atual situação de precariedade da RESEX Chico Mendes está relacionada com a ausência de articulação entre a UC de uso sustentável e políticas de desenvolvimento. Isto porque desde a criação da RESEX, o negócio da borracha já se encontrava falido e, mesmo diante deste contexto, não houve articulação com políticas de desenvolvimento capazes de garantir a geração de renda aliada à sustentabilidade ambiental. O preço muito baixo da borracha e a dificuldade encontrada pelos seringueiros para escoar a produção levou-os ao quase abandono dos seringais e à substituição da atividade extrativista pela pecuária (DRUMMOND \& FRANCO, 2009). Conforme demonstra os autores, esta mudança no sistema econômico da RESEX resultou em maior degradação ambiental, sinalizando que não é possível garantir a conservação da biodiversidade em UCs de uso sustentável com economias precárias e dissociadas de políticas de desenvolvimento compatíveis com o projeto da sustentabilidade.

\section{3- AS UNIDADES DE CONSERVAÇÃO DE USO SUSTENTÁVEL}

As UCs de uso sustentável do Mosaico do Baixo Rio Negro são: a Resex do Rio Unini, a RDS Puranga Conquista, a RDS do Amanã, a RDS do Rio Negro, a RDS do Tupé, a APA Margem Direita do Rio Negro, a APA Margem Esquerda do Rio Negro Setor Aturiá/Apuazinho e a APA Margem Esquerda do Rio Negro - Setor TarumãAçu/Tarumã-Mirim.

A maioria das UCs que formam o Mosaico do Baixo Rio Negro, tanto de proteção integral como de uso sustentável, foi criada anteriormente à promulgação da Lei do SNUC, que ocorreu em 2000. A Lei do SNUC tornou obrigatória a consulta pública para a criação de UCs. Conforme o Capítulo IV- Da Criação, Implantação e Gestão das Unidades de Conservação, Artigo 22, § $2^{\circ}$ desta lei:

A criação de uma unidade de conservação deve ser precedida de estudos técnicos e de consulta pública que permitam identificar a localização, a dimensão e os limites mais adequados para a unidade (BRASIL, 2000). 
Deste modo, a consulta pública não fez parte dos procedimentos para a criação de muitas das UCs que atualmente integram o Mosaico, o que gerou conflitos, pois a região apresenta diversos tipos de ocupação humana, como população urbana concentrada em municípios, bem como populações ribeirinhas residentes em localidades e comunidades dispersas pelos numerosos ecossistemas de águas pretas (FVA, 2011). O Mosaico do Baixo Rio Negro, reconhecido em 2010, surgiu como uma oportunidade para viabilizar a participação da população local nos procedimentos de criação, implantação e gestão de UCs na região (CARDOSO et al., 2010).

Conforme a FVA (2011), a economia do baixo rio negro é baseada no extrativismo animal e vegetal e nas agriculturas de subsistência e comercial. Na região abarcada pela Bacia do Rio Negro, o extrativismo praticado é resultado do processo histórico de ocupação humana, desde a pré-história até os dias de hoje. Atualmente, o extrativismo praticado concentra-se em alguns recursos naturais, tais como: os cipós ambé, titica e timbó-açu; a castanha-da-Amazônia; o óleo de copaíba; os peixes comestíveis e ornamentais; os quelônios aquáticos; o açaí; o buriti; a bacaba; o breu; a andiroba; o arumã; e a seringa. Na agricultura de subsistência, destacam-se a produção de mandioca, cará e banana. Na agricultura comercial familiar, destacam-se produtos como a banana, a mandioca, o abacaxi, a melancia, o mel-de-abelha, a mangarataia, o milho e o cará.

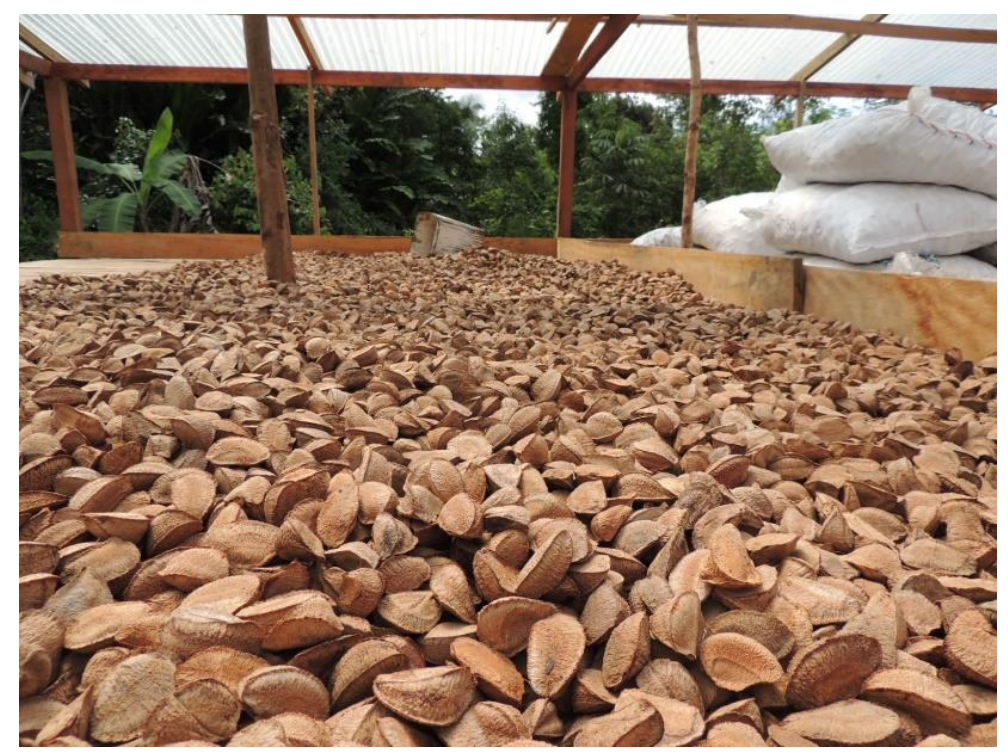

Ilustração 3- Extrativismo da Castanha-da-Amazônia no Baixo Rio Negro. Autor: Desconhecido. Fonte: www.amazoniasocioambiental.com.br. 


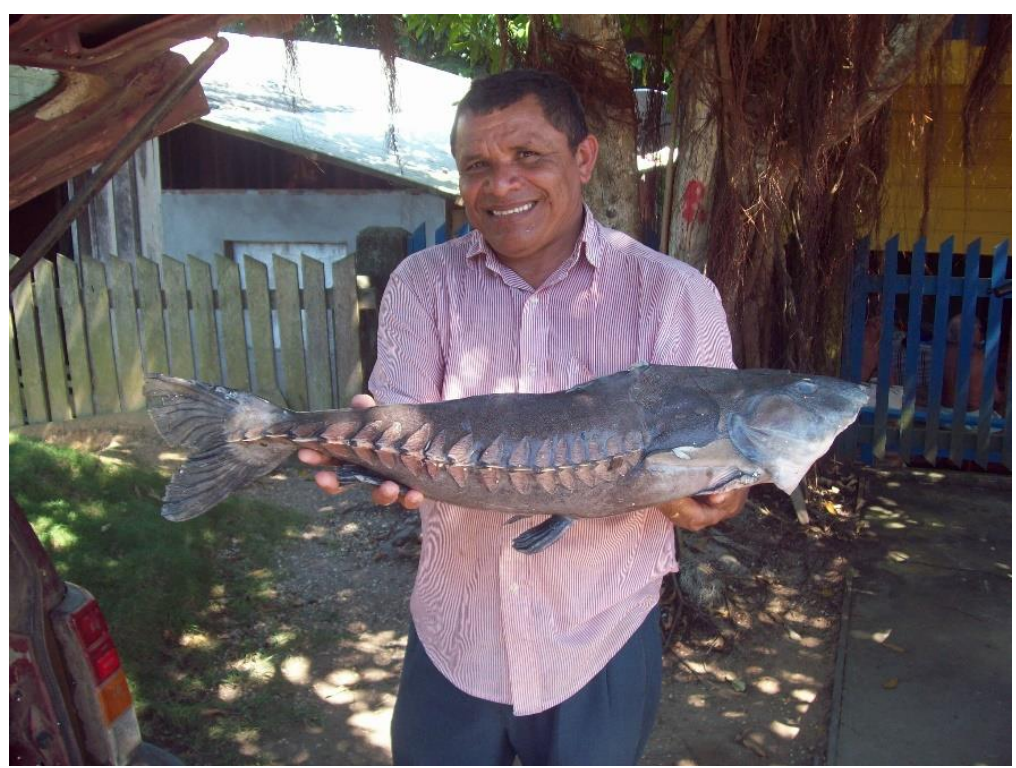

Ilustração 4- Comerciante de produtos do extrativismo animal. Novo Airão/AM. Autora: Carolina Azevedo. Agosto/2014.

O cenário demográfico e econômico da região do Baixo Rio Negro e as dificuldades enfrentadas pelos órgãos ambientais governamentais, sobretudo a falta de recursos para o reassentamento e a indenização dos moradores das UCs de proteção integral criadas, fez das UCs de uso sustentável uma alternativa de mais fácil execução imediata. As UCs de uso sustentável facilitam a resolução de conflitos socioambientais surgidos com a criação de UCs de proteção integral durante as décadas de 1980 e 1990, quando os procedimentos de consulta pública não eram obrigatórios (FVA, 2011). As UCs de uso sustentável implicam a noção de que para explorar os recursos naturais nelas presentes é necessário o manejo sustentável, considerando a conservação dos recursos naturais a longo prazo, de modo que eles permaneçam disponíveis para as futuras gerações.

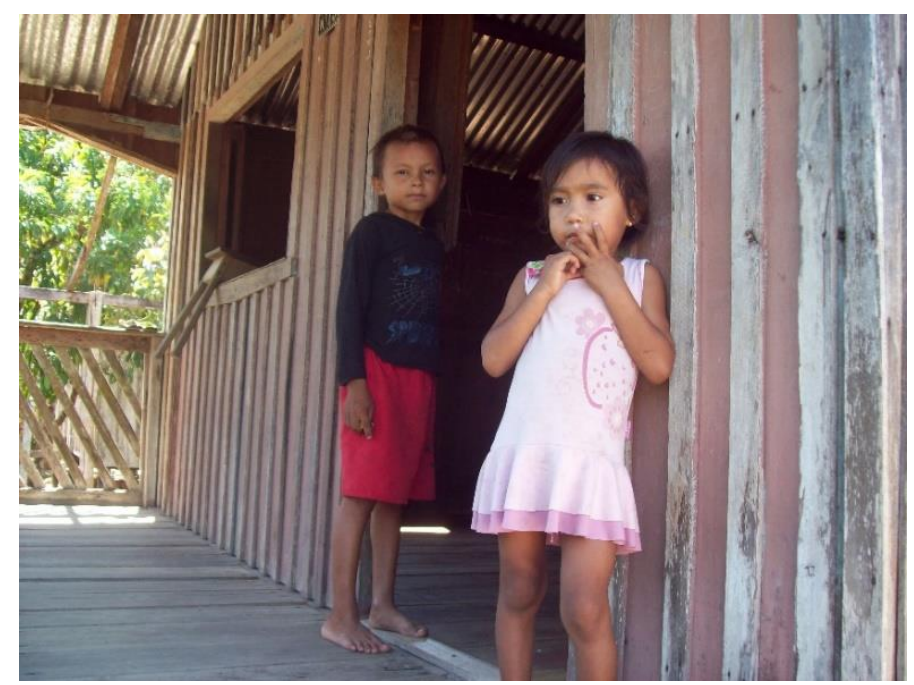

llustração 5- Ribeirinhos da Resex do Unini. Novo Airão/AM. Autora: Carolina Azevedo. Agosto/2014. 


\subsection{1- A RESEX DO RIO UNINI}

A Reserva Extrativista - RESEX - é uma categoria de UC de uso sustentável prevista no SNUC. Conforme o Artigo 18 desta Lei, a RESEX:

É uma área utilizada por populações extrativistas tradicionais, cuja subsistência baseia-se no extrativismo e, complementarmente, na agricultura de subsistência e na criação de animais de pequeno porte e tem como objetivos básicos proteger os meios de vida e a cultura dessas populações e assegurar o uso sustentável dos recursos naturais da unidade (BRASIL, 2000).

A RESEX do Rio Unini foi criada em 2006, abarcando uma área de aproximadamente 833.352 hectares, dentro dos limites do Mosaico do Baixo Rio Negro. À luz do conceito de RESEX estabelecido pelo SNUC, esta categoria de UC é pertinente ao tipo de economia desenvolvido na região do baixo rio negro, que depende dos produtos oriundos do extrativismo. A RESEX do Rio Unini é gerida pela esfera de poder federal, pelo ICMbio, e conta com o apoio da FVA, ONG ambientalista com sede em Manaus, em razão de convênio de cooperação técnica firmado com o órgão gestor federal.

Ademais, possui estrutura administrativa que permite a cogestão por parte de representações comunitárias locais Assim, a gestão praticada na RESEX do Unini conta com a participação da Associação dos Moradores do Rio Unini - AMORU. A RESEX do Unini também recebe apoio do ARPA. Esta UC engloba cerca de 99\% da Bacia do Unini, sendo responsável pela proteção de grande parte dos recursos hídricos da região (FVA, 2011).

Além da previsão da cogestão por parte das representações comunitárias locais, durante o processo de criação da RESEX do Rio Unini foram realizadas consultas públicas, conforme estabelecido na Lei do SNUC. A criação da RESEX promoveu uma diminuição nos conflitos socioambientais existentes na região do baixo rio negro, que há décadas impactam de forma negativa a implementação das UCs na região (FVA, 2011).

A RESEX do Rio Unini é vizinha do PNJ e da RDS do Amanã. O conjunto dessas três UCs forma um importante bloco de áreas protegidas para a conservação da biodiversidade, muito rica na região, apresentando significativa variedade de insetos, peixes, mamíferos, além das espécies florísticas. Inclui espécies carismáticas, como por 
exemplo, o pirarucu (Arapaima gigas), o tracajá (Podocnemis unifilis) e a onça-pintada (Panthera onca) (FVA, 2011).

A RESEX é composta por áreas cobertas de Floresta Ombrófila Densa e áreas de contato com Campinarana. Os moradores da RESEX fazem uso de diversos produtos vegetais oriundos da biodiversidade local, como os cipós, a castanha- daAmazônia, a seringa, o buriti e o arumã (FVA, 2011).

Atualmente, na RESEX do Unini, está em andamento o Projeto Castanha-daAmazônia. Este é um projeto piloto que visa a geração de renda e de emprego, com foco na produção da castanha-da-Amazônia. A responsável técnica pelo projeto é a ONG ambientalista FVA. A castanha é produzida e beneficiada pelos próprios moradores da RESEX. Além disso, as comunidades locais também foram responsáveis pela construção de uma Central Agroextrativista, local onde a castanha é produzida, desidratada e embalada, sendo transformada em um produto adequado à comercialização. O projeto representa uma importante oportunidade para os ganhos de autonomia e para a geração de renda para as comunidades ribeirinhas que residem no interior da RESEX, uma vez que o processo produtivo é controlado quase que exclusivamente pelos moradores locais, eliminando eventuais atravessadores (ICMbio, 2014).

O projeto auxilia no combate ao desmatamento praticado no PNJ, pois a produção da castanha representa uma alternativa de renda que poderá resultar na redução da demanda pela exploração dos recursos madeireiros presentes no Parque. Iniciado em 2006, o projeto envolveu as comunidades locais em seu planejamento. Neste ano de 2014, os moradores da RESEX puderam colher os frutos do empreendimento: a renda e novas possibilidades para o escoamento da produção (ICMbio, 2014).

O Projeto Castanha-da-Amazônia é um bom exemplo de promoção do desenvolvimento socioeconômico aliado à conservação ambiental da Floresta Amazônica. A Cooperativa Mista Agroextrativista do Rio Unini - COMARU e a FVA são as principais gestoras do empreendimento. Devido ao sucesso do projeto, no momento atual, os moradores da RESEX estudam as possibilidades de desenvolver novos empreendimentos na Reserva que sejam similares ao Projeto Castanha-da-Amazônia. 
Eles analisam a viabilidade para a produção de farinha e de banana desidratada, de forma sustentável, como empreendimentos futuros (ICMbio, 2014).

O contexto da RESEX do Rio Unini demonstra que uma UC de uso sustentável tem potencial para desenvolver uma economia de base sustentável aliada à conservação ambiental, caso sejam implementados nas UCs ações complementares como o Projeto Castanha-da-Amazônia descrito nos parágrafos acima. UCs criadas e não implantadas, sem projetos de desenvolvimento sustentável que as apoiem e sem recursos financeiros, dificilmente irão promover a conservação ambiental e o desenvolvimento socioeconômico de suas comunidades.

\subsection{2- RDS PURANGA CONQUISTA}

A RDS Puranga Conquista é a mais recente UC criada dentro da área do Mosaico do Baixo Rio Negro. A Lei Estadual no 4015, de 24 de março de 2014, oficializou a criação da RDS. A nova UC está localizada nos municípios de Manaus e Novo Airão, abrangendo uma área de aproximadamente 76.936 hectares. A RDS Puranga Conquista originou-se da redelimitação e recategorização de parte do PAREST Rio Negro Setor Sul. A área destinada à RDS Puranga-Conquista é formada por $85 \%$ de área proveniente da redelimitação e recategorização do Parque e de 15\% de área que anteriormente pertencia à APA da Margem Esquerda do Rio Negro Setor Aturiá (ISA, 2014).

Conforme o ISA, a RDS foi denominada Puranga Conquista em razão do termo puranga significar bela em Nheengatu, língua amazônica geral. Assim, puranga conquista significa bela conquista. A RDS recebeu este nome por ter sido objeto de reivindicação dos moradores da área do PAREST Rio Negro Setor Sul. Os residentes do Parque pertencem a comunidades indígenas das etnias Baré e Kambeba, e a comunidades ribeirinhas. Eles já habitavam a área desde antes da criação do Parque, e eram incompatíveis com a categoria da UC, inserida no grupo de proteção integral, que permite apenas o uso indireto dos recursos naturais. Isto justificou a recategorização da maior parte do Parque e a criação da RDS.

A criação do PAREST Rio Negro Setor Sul implicou em perdas para as comunidades ribeirinhas e indígenas, pois impediu a instalação de infraestrutura e a implementação de políticas públicas. Os moradores do PAREST Rio Negro Setor Sul 
reivindicaram o direito de permanecer e de continuar retirando o seu sustento e de suas famílias. Em 2006, os moradores do Parque criaram o Fórum Permanente em Defesa das Comunidades Ribeirinhas de Manaus - FOPEC. O aprimoramento da organização dos moradores do Parque resultou na proposta de recategorização, elaborada pelo Instituto de Pesquisas Ecológicas - IPÊ, em 2010, que foi incorporada no Plano de Gestão do PAREST Rio Negro Setor Sul no mesmo ano. Em dezembro de 2010, a Lei Estadual № 3.572 autorizou o governo do Estado do Amazonas a recategorizar as áreas de uso das populações tradicionais localizadas dentro do Parque como RDS. Para isso, foram realizados estudos das áreas de uso das populações tradicionais e feitas negociações com diversas instâncias de poder atuantes na área objeto de recategorização, como o INCRA, a FUNAI e a Marinha. Após longo processo de negociação com as entidades, a RDS Puranga-Conquista foi criada em março de 2014 (ISA, 2014).

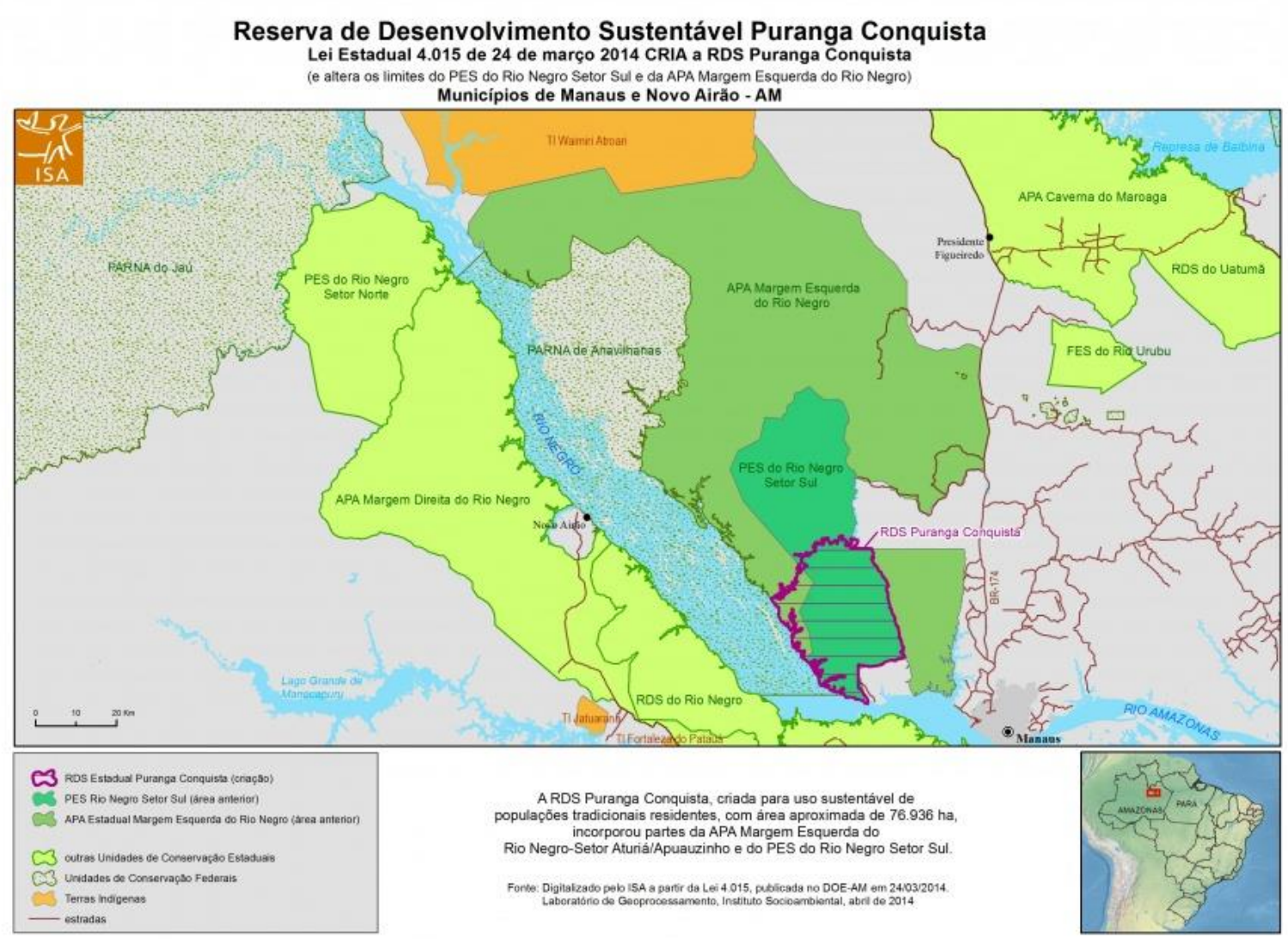

Ilustração 6- Mapa da RDS Puranga Conquista. Autor: Desconhecido. Fonte: www.socioambiental.org.br.

De acordo com o SNUC, a RDS corresponde a uma UC de uso sustentável que abriga populações tradicionais dentro de sua área, as quais empregam sistemas sustentáveis de exploração dos recursos naturais, desenvolvidos ao longo das gerações 
e condizentes com as condições ecológicas locais. Os objetivos da RDS consistem em conservar a natureza, bem como garantir às populações tradicionais a reprodução e a melhoria de seus modos de vida. Assim, a RDS assegura às populações tradicionais a exploração sustentável dos recursos naturais existentes na área e visa valorizar o conhecimento tradicional e as técnicas de manejo por elas desenvolvidas. A RDS é de domínio público e sua gestão deve ser realizada por um Conselho Deliberativo multisetorial, constituído por representantes do governo, de ONGs, das populações tradicionais, do setor privado e demais atores com atuação na RDS. Numa RDS, deve ser considerado o equilíbrio entre o tamanho da população e as possibilidades de conservação da biodiversidade. Além disso, nesta categoria de UC é permitida a substituição da cobertura vegetal nativa por espécies cultiváveis em áreas previstas no zoneamento e no Plano de Manejo, além da exploração sustentável dos recursos naturais (ISA, 2014).

Somente a médio e longo prazo será possível saber se a RDS Puranga Conquista será eficaz como estratégia de conservação. A área da RDS encontra-se integralmente inserida no município de Manaus, e corresponde a 6,22\% da área desta unidade federativa, que de acordo com o Instituo Brasileiro de Geografia e EstatísticaIBGE, abriga uma população de aproximadamente 1.646 .602 habitantes. Trata-se, portanto, de um município bastante populoso, o que é um potencial para pressões e conflitos pelos recursos da RDS. As comunidades residentes na RDS praticam a agricultura de subsistência e comercial em pequena escala, a pesca, a extração de madeira e o turismo, atividades que quando não planejadas com objetivos de aliar geração de renda e conservação ambiental impactam de forma bastante negativa a manutenção da biodiversidade. A RDS é o habitat de espécies endêmicas amazônicas, como o primata Sauim-de- Coleira (Sanguinus bicolor) Além disso, Puranga Conquista abriga as Bacias Hidrográficas dos rios Cuieiras e Tarumã-Mirim, muito importantes para a manutenção dos serviços ecológicos prestados pelos ecossistemas da região.

\subsection{3- RDS DO AMANÃ - RDSA}

A RDSA foi criada em 1998, abarcando uma área de aproximadamente 2.313.000 hectares, com o objetivo de conectar a RDS de Mamirauá ao PNJ. É gerida pela esfera de poder estadual, permitindo a cogestão pelas comunidades locais organizadas. Parte significativa da RDS está inclusa nos limites da Bacia do Rio Negro. 
Portanto, Amanã tem papel importante na preservação dos recursos hídricos da região e, consequentemente, na manutenção dos serviços ecológicos (FVA, 2011).

A categoria RDS surgiu em 1996, tendo sido incorporada pelo SNUC em 2000. A RDS Mamirauá foi a primeira a ser criada. Na década de 1990, a então Estação Ecológica Mamirauá implementou um sistema de cogestão, por meio da celebração de um acordo entre a ONG Sociedade Civil Mamirauá e o governo do Amazonas. Posteriormente, a ONG propôs ao governo estadual a recategorização da ESEC como uma nova categoria de UC, a RDS. A criação da ESEC Mamirauá foi proposta ao governo do Amazonas pelo fotógrafo Luís Cláudio Marigo e pelo biólogo José Márcio Ayres, em 1985. Esses profissionais atuavam na área da ESEC. O objetivo principal que norteou a criação da ESEC Mamirauá foi a proteção do Uacari Branco (Cacajao calvus calvus). Na época, a espécie constava na lista vermelha de espécies ameaçadas de extinção do Brasil e da IUCN. Em 1986, a demanda de Marigo e de José Márcio Ayres foi atendida e por meio do Decreto do Governo do Amazonas no 12.836, de 09 de março de 1990, foi criada a ESEC Mamirauá. A UC abarcou uma área de aproximadamente 1.124.000 hectares (PERALTA \& QUEIROZ, 2006).

A ESEC é uma UC de proteção integral e, portanto, não permite moradores dentro de sua área. No entanto, dentro dos limites da ESEC Mamirauá, anteriormente a sua criação, já havia comunidades residentes. O próprio Ayres assumiu o compromisso com os moradores da ESEC de, em um futuro próximo, buscar enquadrar o Mamirauá em uma categoria de UC compatível com a permanência de seus moradores. A solução foi a criação de uma nova categoria, a RDS. O objetivo da recategorização foi assegurar a conservação ambiental a longo prazo, engajar a população local nas ações de conservação, garantir a sua participação nos processos de planejamento e gestão da UC, bem como promover a prática do manejo sustentável dos recursos naturais presentes (PERALTA \& QUEIROZ, 2006).

A nova categoria criada visava combinar conhecimento científico e tradicional na conservação e manejo da biodiversidade. Para tanto, a RDS requer um programa forte de pesquisa científica. Numa RDS, o conhecimento gerado pela pesquisa tem o papel de subsidiar a elaboração de seu Plano de Manejo. A RDS Mamirauá conta com uma unidade de pesquisa, o Instituto de Desenvolvimento Sustentável Mamirauá - IDSM, criado em 1999. O IDSM é um centro de pesquisa fomentado e supervisionado pelo Ministério da Ciência, Tecnologia e Inovação - MCTI, havendo interesse do governo em 
transformar a RDS em um laboratório de pesquisa aplicada. Em síntese, a RDS corresponde a um modelo de UC que tem como meta o manejo participativo aliado à pesquisa científica que o subsidia (PERALTA \& QUEIROZ, 2006; IDSM, 2014).

O IDSM atua nas RDSs Mamirauá e Amanã, por meio dos Programas de Agroecossistemas, Gestão Comunitária, Manejo de Pesca, Manejo Florestal Comunitário, Qualidade de Vida e Turismo de Base Comunitária. A RDS do Amanã ocupa uma vasta área localizada entre os rios Negro e Japurá, situada na região central do Estado do Amazonas, cobrindo áreas dos municípios de Barcelos, Coari, Codajós e Maraã. $\mathrm{Na}$ área da RDSA, ocorrem ecossistemas de várzea e de terra firme, o que resulta na diversificação sociocultural das comunidades que residem em Amanã. $A$ RDSA corresponde a uma das maiores áreas protegidas de floresta tropical da América do Sul, que associada aos seus vizinhos PNJ e RDS Mamirauá forma um bloco contíguo de área destinada à conservação de aproximadamente 5.746.000 hectares (IDSM, 2014). Na RDSA, a biodiversidade presente é rica, com ocorrência de uma ampla variedade de espécies de pássaros, mamíferos e roedores, servindo também de habitat para diversas espécies em extinção, como o peixe-boi (Trichechus inunguis) (ISA, 2014).

Conforme o Instituto Socioambiental, dentre as atividades desenvolvidas pelos moradores da RDSA estão a agricultura itinerante, a pesca, a caça, a exploração madeireira e a pecuária. A agricultura itinerante é caracterizada pelo sistema de derrubada e queimada. Na RDSA, ocupa áreas de mata virgem e de capoeiras. Nas áreas de terra firme da RDSA, os roçados normalmente permanecem no local por até dois anos, fazendo seu percurso itinerante após este período, quando ocorre o desgaste do solo. O solo destinado à produção agrícola é deixado em sistema de pousio por um período de dois a cinco anos, com a finalidade de regeneração. De acordo com este sistema itinerante, a agricultura vai ocupando novas áreas na RDSA de forma constante.

Para Araújo, Gama e Lima (2006), a pecuária está presente na RDSA há algumas gerações. Os principais produtores são ribeirinhos que pretendem somar a atividade pecuária aos seus regimes econômicos familiares constituídos da pesca, da caça, da agricultura e do extrativismo. Praticada em pequena escala na RDSA, a pecuária na Amazônia está intimamente relacionada com o desmatamento, sendo responsável em grande parte pela degradação ambiental da floresta tropical, pois para estabelecer pastos é preciso desmatar. A prática da pecuária na RDSA tem sido um dos 
principais obstáculos para a concretização dos objetivos de conservação da unidade. Isto ocorre porque há o risco da pecuária tomar maiores proporções na RDSA, uma vez que existe a possibilidade da chegada de novos criadores, com maior potencial econômico, aptos a adquirirem maiores proporções de terras por meio da compra de áreas dos moradores da RDSA, o que é ilegal. Este processo é conflitivo com o desenvolvimento de atividades sustentáveis na RDSA, capazes de gerar renda e promover a conservação ambiental de forma concomitante.

\subsection{4- RDS DO RIO NEGRO}

A RDS do Rio Negro foi criada em 2008 por meio de Lei Estadual do Governo do Amazonas nํ 3355. Ocupa uma área de cerca de 103.086 hectares. Situa-se entre os municípios amazonenses de Manacapuru, Iranduba e Novo Airão. A fitofisionomia predominante na área da RDS é a Floresta Ombrófila Densa. A RDS do Rio Negro é gerida pela instância estadual de poder, permitindo a cogestão participativa. Esta UC foi criada a partir do desmembramento da APA da Margem Direita do Rio Negro, unidade que também faz parte do Mosaico do Baixo Rio Negro (ISA, 2014).

Conforme o Instituto Socioambiental, a maior parte dos moradores da RDS do Rio Negro é constituída de pequenos proprietários rurais e posseiros. Atualmente, cerca de 950 famílias residem na área da Reserva, sendo esta uma UC bastante populosa. Para agravar ainda mais o problema populacional existente na RDS do Rio Negro, a nova ponte construída sobre o Rio Negro representa uma ameaça significativa à concretização do objetivo principal planejado para a RDS, sendo este a conservação ambiental aliada ao desenvolvimento social e econômico da população local. Isto ocorre porque a ponte facilita os movimentos populacionais migratórios para a RDS, podendo ocorrer um incremento desta dinâmica e, consequentemente um aumento quantitativo na população residente da UC. Além desse problema relacionado com o aumento da população, a nova ponte facilita a comercialização de produtos entre a RDS e os municípios vizinhos, aumentando a pressão sobre os recursos naturais existentes na unidade. Este contexto exigirá um maior controle sobre a exploração e manejo dos recursos naturais da RDS, de modo que a degradação ambiental e a perda de biodiversidade seja evitada.

Conforme a Portaria do INCRA no 64, de 15 de dezembro de 2009, a RDS do Rio Negro obteve reconhecimento e seus moradores tornaram-se aptos a participarem 
do Programa Nacional da Agricultura Familiar - PRONAF, em específico da linha "Crédito Instalação e Fortalecimento da Agricultura Familiar" pertencente ao Programa. Conforme descrito no normativo, esta medida visa fortalecer a agricultura familiar na RDS como modo de impedir o avanço das atividades produtivas ambientalmente degradantes e socialmente injustas dentro dos limites da UC, como por exemplo a exploração madeireira ilegal que resulta em desmatamento, muito frequente na RDS.

\subsection{5- RDS DO TUPÉ}

A RDS do Tupé foi criada em 2005, pelo Decreto Municipal no 8044/2005, abrangendo uma área de aproximadamente 11.973 hectares. Sendo assim, a esfera de gestão da RDS é municipal, permitindo a cogestão por representantes das comunidades locais (SEMMAS, 2014). Seis comunidades residem na RDS, somando um total de cerca de setecentos habitantes. A RDS é banhada pelas águas do Rio Negro, que correm e se distribuem de modo emaranhado sobre a paisagem da Reserva. Devido a esta característica geográfica e hidrológica, a RDS recebeu o nome de Tupé, que significa entrançado. A RDS possui significativo potencial turístico devido a sua beleza cênica. Suas belas praias são reveladas durante o período da vazante, atraindo um grande número de turistas, o que causa impacto antrópico considerável sobre o ambiente natural da RDS. Deste modo, o turismo na RDS representa um desafio para seus objetivos de conservação ambiental (BARROS et al., 2008).

\subsection{6- AS APAs DO MOSAICO DO BAIXO RIO NEGRO}

A Área de Proteção Ambiental - APA - é uma UC do grupo de uso sustentável prevista no SNUC. Conforme o Artigo 15 desta lei, a APA:

É uma área em geral extensa, com um certo grau de ocupação humana,
dotada de atributos abióticos, bióticos, estéticos ou culturais especialmente
importantes para a qualidade de vida e o bem-estar das populações
humanas, e tem como objetivos básicos proteger a diversidade biológica,
disciplinar o processo de ocupação e assegurar a sustentabilidade do uso
dos recursos naturais (BRASIL, 2000).

Ainda conforme o SNUC, Artigo 15, §1, §2 e §5, a APA é constituída por terras públicas e privadas, sendo permitido ao Poder Público o estabelecimento de normas e restrições relativos ao uso das propriedades privadas localizadas dentro da APA, respeitando-se os limites constitucionais. As APAS possuem Conselhos presididos pelo órgão responsável por 
sua administração, constituídos de representantes dos órgãos públicos, de organizações da sociedade civil e da população residente.

\subsubsection{1- A APA Margem Direita do Rio Negro}

A APA Margem Direita do Rio Negro foi criada por meio do Decreto Estadual no 16.498, de 02 de abril de 1995. Sua esfera de gestão é estadual e o seu órgão gestor é o Centro Estadual de Unidades de Conservação do Amazonas- CEUC/AM. A APA é cogerida por um conselho multisetorial, que auxilia na tomada de decisões. Em 2001, a APA foi redelimitada por meio de Lei Estadual no 2646. A partir da redelimitação, a APA foi diminuída passando a ter 566.365 hectares. Posteriormente, em 2008, por meio da Lei Estadual № 3355, a APA foi novamente redelimitada, tendo sido ainda mais diminuída, deste modo passando a cobri uma área de 461.741 hectares. A mais recente redelimitação da APA Margem Direita do Rio Negro ocorreu para viabilizar a criação da RDS do Rio Negro, a partir da recategorização de parte de sua área (ISA, 2014). No momento, os gestores do Mosaico do Baixo Rio Negro estão debatendo sobre uma nova proposta de redelimitação e recategorização da APA, para viabilizar a criação de uma nova RDS (Ata da 9 Reunião do Conselho Consultivo do Mosaico do Baixo Rio Negro - CCMBRN).

A APA Margem Direita do Rio Negro é drenada por rios de águas brancas e pretas e abarca regiões de várzeas e de terras firmes, cuja fitofisionomia predominante é a Floresta Ombrófila Densa. Ela exerce um importante papel na preservação de extensas áreas florestais localizadas na Planície Central Amazônica. Nestas áreas, são encontradas espécies da fauna e da flora amazônicas relevantes para a conservação, como o jacaré-açu (Melanosuchus niger), a onça-pintada (Panthera onca) e a ariranha (Pteronura brasiliensis). A biodiversidade presente na APA é bastante variada, com destaque para a avifauna e para a herpetofauna (ISA, 2014).

\subsubsection{2- A APA Margem Esquerda do Rio Negro}

A APA Margem Esquerda do Rio Negro também foi criada em 1995, pelo Decreto Estadual no 16.498, de 02 de abril. Ela abarca dois setores: o Setor Aturiá/Apuazinho e o Setor TarumãAçu/Tarumã-Mirim. Sua esfera de gestão é estadual, estando a cargo do CEUC/AM. Em março de 2014, a APA foi redelimitada, cedendo parte de sua área para a criação da RDS Puranga Conquista, em março de 2014. A APA, que inicialmente tinha 643.215 hectares, passou a ter 611.008 hectares. Ela está localizada no interflúvio Uatumã-Trombetas, sendo 
drenada pelo Rio Cuieiras. A cobertura vegetal da APA é formada por Chavascais, Campinaranas, Floresta Ombrófila Densa e por fitofisionomias típicas de áreas submontanhosas (ISA, 2014).

\subsubsection{3- A APA Margem Esquerda do Rio Negro - Setor Aturiá/Apuazinho}

Conforme o ISA, a APA Margem Esquerda do Rio Negro Setor Aturiá/Apuazinho atua como zona de amortecimento do Parque Nacional de Anavilhanas, exercendo um papel importante na conservação dos ecossistemas que integram o arquipélago de Anavilhanas. Ela é habitat de diversas espécies relevantes para a conservação, como o Saium-de-Coleira (Saguinos bicolor) e o Gavião Real (Harpia harpyja). Na APA, residem cerca de cem famílias. Dentre as atividades desenvolvidas pelos moradores da UC, destacam-se a caça, a agricultura de subsistência e comercial, a pesca de subsistência e a extração de madeira. Há necessidade de manejo adequado da exploração dos recursos naturais, para evitar o risco de degradação ambiental. $\mathrm{Na}$ área da APA, ocorre sobreposição com um assentamento da reforma agrária gerido pelo INCRA, o PDS Cuieiras-Apuaú, que precisa estabelecer estratégias de uso sustentável dos recursos naturais, de forma a não prejudicar os objetivos de conservação ambiental estabelecidos para a APA.

\subsubsection{4- A APA Margem Esquerda do Rio Negro - Setor Tarumã-Açu/Tarumã-Mirim}

A APA Margem Esquerda do Rio Negro - Setor Tarumã-Açu/Tarumã-Mirim foi criada em 1995, abarcando uma área de 56.793 hectares. A cobertura florestal da APA é formada, em sua maior parte, por áreas de Floresta Ombrófila Densa, com ocorrência em menor escala de áreas cobertas por Campinaranas. Ela desempenha um papel importante como zona de amortecimento do PAREST Rio Negro Setor Sul. A área da APA é drenada pelas bacias Tarumã-Açu e Tarumã-Mirim (FVA, 2011).

$\mathrm{Na}$ APA, ocorre significativa ocupação humana, inclusive sobreposição com o Projeto de Assentamento- PA Tarumã-Mirim, gerido pelo INCRA. Este PA foi implementado em 1992, sendo portanto anterior à criação da APA. Ele abriga cerca de 1.042 famílias, organizadas em treze associações comunitárias. Este projeto de assentamento representa a simbiose do espaço urbano com o espaço rural, devido a sua proximidade geográfica com Manaus e também em razão da forte influência nos assentados dos modos de vida urbanos (BILLACRÊS et al., 2012). 
O PA Tarumã-Mirim ocupa uma área de 42.910,76 hectares dentro da APA. Foi criado pelo INCRA com o objetivo de promover a ocupação de áreas agricultáveis do município de Manaus por agricultores sem terras, de modo a integrá-los na dinâmica produtiva da capital amazonense. A intenção foi estimular a produção de alimentos para abastecer parte do mercado de Manaus. No entanto, o projeto de assentamento apresenta uma característica híbrida, pois seus lotes são destinados a finalidades diversas. Alguns são destinados somente para o lazer. Nestes lotes, os proprietários geralmente não residem e também não estabelecem sistemas de produção agrícola. Normalmente, os lotes do PA que são destinados para a oferta de lazer são aqueles que foram repassados a outros proprietários, pelos primeiros assentados (BILLACRÊS et al., 2012).

Segundo o autor, ocorre no PA Tarumã- Mirim a ocupação de lotes por famílias migrantes de outros estados e municípios. Nestes, há produção de alimentos como mandioca, farinha e cupuaçu, de forma paralela ao trabalho externo. Para alguns assentados desta categoria de ocupação, a maior parte da renda provém do trabalho externo. Mas, há também no PA lotes que são ocupados por agricultores familiares que se dedicam à produção de alimentos de forma exclusiva, com base nos recursos naturais existentes na APA. Nesses lotes, a força de trabalho empregada é essencialmente familiar, sendo os processos e meios de vida criados pelos próprios assentados. É também nos lotes trabalhados por agricultores familiares que se dedicam integralmente à terra que está a maior parte da produção do assentamento que é escoada para Manaus. A principal atividade desenvolvida por este tipo de trabalhador é o cultivo de roças. Nelas, são produzidos cupuaçu, mandioca, macaxeira, açaí, banana, bacaba, patoá dentre outros produtos. (BILLACRÊS et al., 2012).

Billacrês et al. (2012) argumentam que o PA Tarumã-Mirim fracassou em seu objetivo principal de abastecer Manaus de gêneros alimentícios e de gerar renda para os assentados. Para eles, o principal motivo do fracasso está relacionado à falta de manutenção em infraestrutura, principalmente de estradas e ramais, que ligam o assentamento à capital do Amazonas. Esta lacuna teve como consequência a dificuldade para os assentados em escoar a produção para Manaus. Há ainda o fato de que a relação ser humano-natureza no PA Tarumã-Mirim promove modificações nos ecossistemas, uma vez que o ato de produzir é igualmente o ato de criar espaços. A criação do projeto de assentamento em questão fomentou as ameaças aos ecossistemas da APA Margem Esquerda do Rio Negro - Setor Tarumã-Açu/Tarumã- 
Mirim. Por exemplo, a construção de estradas para escoar a produção do assentamento para Manaus acarretou no aumento do desmatamento na APA. Este cenário é agravado pela falta de fiscalização por parte dos órgãos ambientais competentes, no que tange à exploração e ao uso adequado dos recursos naturais pelos assentados.

As dificuldades enfrentadas pela APA Margem Esquerda do Rio Negro- Setor Tarumã-Açu/Tarumã-Mirim demonstram que o alcance de resultados positivos para as metas de conservação depende do comprometimento dos diversos atores atuantes na área protegida pela UC. O sucesso da conservação ambiental depende também da transversalidade de políticas ambientais, de reforma agrária e de desenvolvimento social implementadas pelo Estado (BILLACRÊS et al, 2012).

\section{4- O CONTEXTO DA POLÍTICA AMBIENTAL NACIONAL E A CRIAÇÃO DO MOSAICO DO BAIXO RIO NEGRO}

O Mosaico do Baixo Rio Negro obteve reconhecimento oficial em 2010, por meio da Portaria MMA № 483, de 14 de dezembro. A área do Mosaico foi formada a partir do agrupamento de UCs que já haviam sido criadas à época, pois as UCs que surgiram posteriormente são produtos de redelimitação e recategorização das UCs préexistentes. A maior parte das UCs que compõem o Mosaico foi criada na década de 1990, sobretudo em 1995. Somente neste ano, foram criadas as APAs Margem Direita e Margem Esquerda do Rio Negro e os Parques Estaduais. Também na década de 1990, foi criada a RDS do Amanã. Na década de 1980, foram criados os Parques Nacionais de Anavilhanas e do Jaú. A partir de 2000, foram criadas a RDS do Tupé, do Rio Negro e Puranga-Conquista, bem como a RESEX do Rio Unini, conforme já mencionado.

Conforme entendimento do ICMbio, os mosaicos surgem no Brasil como uma alternativa capaz de solucionar conflitos existentes entre conservação ambiental e direitos das populações residentes no entorno e em áreas de UCs. O modelo de mosaico busca conciliar conservação e população residente por meio da gestão integrada e participativa das áreas protegidas que o irão compor, compatibilizando a biodiversidade com a valorização da sociodiversidade e com a promoção do desenvolvimento sustentável, dentro de um contexto regional.

A política de mosaico de áreas protegidas ganhou relevância no Brasil na primeira década de 2000, tendo sido constituídos em território nacional diversos 
mosaicos, situados nos diferentes biomas e na zona costeira. O Edital para a seleção de projetos de formação de mosaicos e elaboração do Plano de Desenvolvimento de Base Territorial Conservacionista do Fundo Nacional do Meio Ambiente, lançado em 2005, deu origem à formação de diversos mosaicos, inclusive o do Baixo Rio Negro.

Além disso, o modelo de mosaico é impulsionado no Brasil de forma concomitante ao aumento do número de UCs criadas em território nacional. Esta ampliação no quantitativo de UCs e, consequentemente, no quantitativo de área por elas ocupada, gerou sobreposições e conectividades anteriormente não existentes, que possibilitaram o trabalho integrado e participativo, bem como trouxeram a reflexão sobre a criação de mosaicos como alternativa de gestão (CARDOSO et al., 2009)

De acordo com Zimmerer (2011), houve um boom na política de conservação ambiental baseada no modelo de áreas protegidas no Brasil, na década de 1990. Assim, o incremento nas áreas protegidas ocorrido neste período resultou da pressão exercida pelos movimentos ambientalistas e sociais, incluindo o movimento dos indígenas de luta pelos direitos aos territórios e de autoria de ONGs atuantes na conservação. Além desses atores, também demandaram incremento nas ações conservacionistas, em especial na criação de UCs, os acordos internacionais multilaterais ambientais ratificados pelo Brasil, como a CDB, aderida pelo Brasil em 1993.

Ainda conforme Zimmerer (2011), a Conferência das Nações Unidas sobre o Meio Ambiente e o Desenvolvimento - CNUMAD ou ECO 92, ocorrida na cidade do Rio de Janeiro, em 1992, reforçou a questão da conservação, tanto na agenda mundial, como brasileira, pressionando o país por ações concretas de proteção da natureza. Diante disso, houve um incremento na política de áreas protegidas no Brasil, em quantidade e área destinada. As UCs que atualmente compõem o Mosaico, que foram criadas na década de 1990, enquadram-se neste contexto político. Durante esta década, 90\% dos recursos que foram destinados para a conservação ambiental na América Latina tiveram suas fontes em organismos internacionais, tais como o Banco Mundial e o Banco Interamericano de Desenvolvimento - BID.

As áreas protegidas correspondem aos principais instrumentos de gestão ambiental da atualidade, direcionadas à proteção da natureza, à sustentabilidade e à gestão participativa. No início da política de áreas protegidas, estas eram criadas com o intuito de preservar sítios naturais que continham significativa beleza cênica. No 
entanto, a política de áreas protegidas passou por mudanças a partir do final do século $\mathrm{XX}$. Com isto, as áreas protegidas começaram a incorporar em seus planos questões sociais, territoriais e econômicas. Consequentemente, as áreas protegidas tornaram-se espaços possíveis para a promoção de justiça social, garantia de direitos territoriais, bem como para a prática da gestão participativa e para o desenvolvimento de um novo modelo de produção e geração de renda, baseado na sustentabilidade (ZIMMERER, 2011).

Atualmente, as áreas protegidas não estão restritas ao cumprimento do dever de proteção à natureza, visto que tais espaços também cumprem funções legais, econômicas e sociais, além daquele relativo à preservação ambiental. Outro aspecto importante, sobretudo quando se analisa o contexto brasileiro, é o de que a política de áreas protegidas está intimamente relacionada ao desmatamento praticado em larga escala e de forma contínua no país. Em outras palavras, muitas áreas protegidas são criadas com o propósito de conter o avanço do desmatamento (ZIMMERER, 2011).

A partir de 2000, a política de áreas protegidas foi fortalecida no Brasil, devido ao surgimento da Lei do SNUC. A Lei do SNUC inovou ao sugerir o Mosaico de Áreas Protegidas como instrumento de gestão, conforme já descrito no primeiro capítulo desta dissertação. A nova lei apenas oficializou o modelo de mosaico, visto que este já vinha sendo idealizado e praticado no Brasil, mesmo antes de sua oficialização na lei.

\section{5- PERCEPÇÕES dOS ATORES SOBRE O PROCESSO DE CRIAÇÃO DO} MOSAICO

\subsection{1- Atores não-governamentais}

O Mosaico do Baixo Rio Negro foi idealizado a partir de 2003. O projeto foi proposto inicialmente por um Grupo de Trabalho - GT do Projeto Corredores EcológicoPCE, ou seja, ele surge das relações interinstitucionais estabelecidas no PCE (CARDOSO et al., 2009). De acordo com Illenseer, gestor da FUNAI, anteriormente consultor do IPÊ e ator ativo no processo de criação do Mosaico, atualmente membro convidado do Conselho Consultivo:

Nos anos de 2003 e 2004, acontece na região do baixo rio negro uma forte articulação institucional, tendo por atores gestores de órgãos governamentais, como o IBAMA, o IPAAM, a SDS, dentre outros, com o propósito de pensar a conservação para o território em questão. Para facilitar 
a articulação entre os gestores, foi estabelecido um pequeno núcleo no município de Novo Airão. Além disso, neste período inicial do projeto de criação do Mosaico, foram realizados os primeiros concursos para o IBAMA, fornecendo novos gestores para as UCs do baixo rio negro. Isto impulsionou a implantação das UCs na região, bem como a elaboração dos planos de manejo, ampliando o conhecimento sobre as demandas de conservação. Inicialmente, o GT do PCE agrupou os gestores com a finalidade de realizar um diagnóstico referente à situação das UCs do baixo rio negro. Durante esta atividade, surgiu a ideia de se formar um mosaico na região. Então, em 2005, o FNMA lançou o edital para a seleção de projetos de formação de mosaicos nos diversos biomas brasileiros e na zona costeira, também com o propósito de promover nos mosaicos o DTBC. O edital foi um grande motivador para que o projeto do mosaico fosse levado adiante. A ONG IPE elaborou a proposta de criação do mosaico e do plano de desenvolvimento de base conservacionista a serem submetidos ao FNMA. O GT então aprovou a submissão da proposta ao FNMA pelo IPÊ. A proposta foi selecionada e os trabalhos para o reconhecimento do Mosaico do Baixo Rio Negro se iniciaram em 2007. Quando o FNMA lançou o edital de mosaicos e DTBC, em 2005, a área que hoje corresponde ao mosaico tinha outra configuração. Por exemplo, ainda não existia a RESEX do Rio Unini. Mas, já havia a reivindicação por sua criação. Também, ainda não havia sido criada a RDS do Rio Negro e de Puranga- Conquista, que são frutos da redelimitação e recategorização de UCs preexistentes. Em outras palavras, o mapa contendo as UCs da região era outro, bem diverso do mapa atual. Além disso, nesta época, diversos conselhos das UCs da região ainda estavam se formando, ou seja, não havia tantos conselhos como hoje. Em agosto de 2008, o grupo de gestores envolvidos com o projeto aprovado pelo FNMA realizou a primeira oficina do mosaico, na qual foi feito um exercício muito semelhante à montagem de um quebra-cabeça. Neste exercício, as UCs representavam peças para serem agrupadas, conforme uma justificativa pertinente. Este exercício gerou como produto três propostas diferentes para o mapa do mosaico. Nesta primeira reunião, foi formado um novo GT para pensar a estratégia de formação do mosaico, constituído por gestores de órgãos governamentais, como o CEUC e o ICMbio, e de ONGs, como o IPÊ e a FVA. Uma das propostas para a criação do mosaico que surgiu nesta primeira oficina foi a de levar o projeto para conhecimento dos conselhos, visando discuti-lo em conjunto. Esta estratégia foi consolidada pelo GT, e o projeto de criação do mosaico foi apresentado e discutido em diversos conselhos de UCs da região. Nos locais onde não havia conselho, foram realizadas reuniões com as comunidades, como no Rio Cuieiras, onde o GT realizou uma oficina para apresentação e discussão do projeto com a participação de cerca de sessenta pessoas. Esta estratégia de levar as discussões para os conselhos e comunidades fez parte da mobilização social para a criação do mosaico. Além do pessoal dos conselhos e das comunidades ribeirinhas, também foram convidados para participar do processo as comunidades indígenas da região, como os Waimiri- Atroari e os indígenas do Rio Cuieiras. Com relação aos Waimiri-Atroari, apesar de terem sido convidados para fazer parte do processo de criação do mosaico, eles não demonstraram interesse em aderir formalmente ao mosaico, pois não solicitaram adesão. Para incentivá-los a fazer parte, o IPÊ e demais parceiros que trabalhavam na construção do mosaico os convidaram para compor o Conselho. Entretanto, também não houve demonstração de interesse por parte desta comunidade indígena quanto à participação no Conselho (informação verbal). ${ }^{6}$

${ }^{6}$ Entrevista concedida em 01 de agosto de 2014, em Novo Airão- Amazonas. 
Conforme informado pelo gestor, a estratégia de mobilização social do GT foi condizente com o objetivo traçado no projeto de formação do Mosaico apresentado pelo IPÊ ao FNMA, que recomendou constituir o mosaico de forma trans-escalar, ou seja, de forma a envolver os diversos atores sociais atuantes na região de cobertura do mosaico. Isto porque, para a criação do Mosaico, foram mobilizados os conselhos das UCs, que são formados por diversos setores da sociedade e também foram mobilizadas as comunidades locais, ampliando a participação na gestão ambiental da região do baixo rio negro.

Para Illenseer,

\begin{abstract}
A principal motivação para a criação do Mosaico do Baixo Rio Negro foi compatibilizar a presença humana nas UCs com os objetivos de conservação ambiental. Com a institucionalização do instrumento do mosaico, através da lei do SNUC, tornou-se possível discutir e implementar na Amazônia um novo tipo de conservação, que envolve as pessoas em sua prática e não mais as considera simplesmente uma ameaça à biodiversidade. O Mosaico do Baixo Rio Negro foi criado para atender ao Artigo 26 da lei do SNUC, principalmente no que diz respeito à implantação de um modelo capaz de compatibilizar a conservação da biodiversidade com a valorização da sociodiversidade, visando promover o desenvolvimento sustentável (informação verbal). ${ }^{7}$
\end{abstract}

Conforme Marco Antônio, membro do Conselho Consultivo, representando o IPÊ e ator no processo de criação do Mosaico:

\begin{abstract}
Em seu início, o projeto de criação do Mosaico do Baixo Rio Negro foi bastante motivado pelo ideário de colocar em prática a gestão integrada de UCs na região. Um dos focos principais que se buscava com a gestão integrada era o de unir forças para promover melhorias na fiscalização das UCs. Além da gestão integrada, outra motivação fundamental para a construção do mosaico foi o reconhecimento e fortalecimento do território, visando trabalhar a conservação ambiental de forma associada com a presença humana nas UCs, dentro de um contexto regional (informação verbal). ${ }^{8}$
\end{abstract}

De acordo com o gestor, um dos principais objetivos que norteou a criação do Mosaico foi a meta de implementar na região do baixo rio negro, entre as diversas UCs existentes, a prática da gestão integrada, visando diminuir os passivos administrativos, tal como a fiscalização precária nas UCs. Além disso, para ambos os gestores supracitados, a criação do Mosaico se deu visando harmonizar a presença de populações humanas e a conservação ambiental nas UCs do baixo rio negro.

\footnotetext{
${ }^{7}$ Entrevista concedida em 01 de agosto de 2014, em Novo Airão- Amazonas

${ }^{8}$ Entrevista concedida em 31 de julho de 2014, em Novo Airão- Amazonas.
} 
Em 2007, o Brasil e a França firmaram um acordo bilateral intitulado Cooperação Técnica Franco-Brasileira de Áreas Protegidas. Os objetivos do acordo consistiram em discutir e experimentar instrumentos de gestão de áreas protegidas franceses e brasileiros, cuja base de funcionamento concentra-se em processos participativos. $O$ acordo deu origem a um programa, cujo corpo técnico era composto por representantes de instituições públicas e da sociedade civil organizada, sendo um de seus objetivos o fortalecimento dos mosaicos no Brasil, entendendo os mosaicos como projetos de desenvolvimento territorial (CARDOSO et al., 2010).

Conforme informado pelo gestor do IPÊ, o Mosaico do Baixo Rio Negro apresenta, desde o início de seu processo de criação, forte viés territorial. Em outras palavras, o fortalecimento da identidade territorial como estratégia para a conservação ambiental e para o desenvolvimento sustentável regional é um dos aspectos fundamentais do Mosaico.

\subsection{2- Atores governamentais}

Na Região Amazônica, as áreas protegidas existentes encontram-se conectadas entre si em termos estruturais e funcionais. Estes conjuntos de áreas protegidas formam grandes blocos cuja finalidade consiste na conservação ambiental in situ e no incentivo ao desenvolvimento sustentável. Cada um desses blocos possui suas próprias identidades territoriais e seus próprios contextos socioambientais (CARDOSO et al., 2009).

Para Priscila Santos, gestora do ICMbio, chefe do PARNA de Anavilhanas e membro do Conselho Consultivo do Mosaico:

Em parte, o Mosaico do Baixo Rio Negro foi criado para unir o que já encontrava-se unido, pois as UCs que o formam já se dispunham conectadas entre si em termos estruturais. Por isso, os gestores que idealizaram o projeto indagavam o porquê de não unir também a gestão dessas unidades. $O$ reconhecimento oficial do Mosaico do Baixo Rio Negro, em 2010, pelo MMA, representou a "coroação" de todo um trabalho prévio complexo que vinha sendo desenvolvido pelo GT e também dos esforços advindos das lutas sociais locais. O GT vinha trabalhando no mapeamento dos atores, na definição da área de abrangência do mosaico, na mobilização social para sua criação, na articulação institucional, na formação do Conselho Consultivo e em outras atividades que foram necessárias para subsidiar o processo de construção do novo mosaico. Um dos principais objetivos de se criar o mosaico foi promover a gestão integrada das UCs em um território comum, com um histórico comum e que já apresentava conectividade ecológica e funcional. Fortalecer as UCs por meio da gestão integrada foi um dos 
objetivos principais que norteou o processo de criação do Mosaico. A questão da conservação ambiental e do desenvolvimento sustentável para a região do baixo rio negro foi compreendida pelos idealizadores do projeto do mosaico como semelhante à situação descrita pela expressão popular "estamos no mesmo barco", muito usada na região. Pensando desta forma, por que não unir forças para contornar as dificuldades? Os idealizadores do projeto pensaram em viabilizar esta união de forças por meio de um instrumento de gestão viável e factível, capaz de propiciar maior poder político para a luta em torno da conservação e da transição para o desenvolvimento sustentável. Também, o Mosaico foi criado para atuar como uma ferramenta de luta política (informação verbal). ${ }^{9}$

Conforme a gestora, um dos principais objetivos que serviu de base para a criação do Mosaico é a promoção da gestão integrada entre as UCs da região. Porém, para Santos, visou-se implantar um sistema de gestão integrada na região do baixo rio negro para fortalecer as UCs, evitando com isso a desafetação das unidades. Além disso, a gestora compreende o Mosaico como um elemento de força política em prol da conservação.

No que diz respeito ao processo de criação do Mosaico, Pablo Pacheco, Presidente do Conselho Consultivo do Mosaico e gestor do CEUC entende que:

As ONGs tiveram papel de destaque na criação do Mosaico e continuam a ter na sua gestão. Sem a atuação das ONGs, principalmente do IPÊ e da FVA, talvez o Mosaico nem mesmo fosse criado. Isto porque os gestores das UCs trabalham numa dinâmica muito intensa, com sobrecarga de atividades. Muitos deles não têm equipes e, às vezes, são responsáveis pela gestão de mais de uma UC. Diante deste cenário, a atuação das ONGs tornou-se fundamental para impulsionar as atividades de conservação ambiental na região (informação verbal). ${ }^{10}$

\footnotetext{
$\overline{{ }^{9} \text { Entrevista }}$ concedida em 01 de agosto de 2014, em Novo Airão- Amazonas.

${ }^{10}$ Entrevista concedida em 01 de agosto de 2014, em Novo Airão- Amazonas.
} 
Para Ana Luiza Figueiredo, gestora do ICMbio, chefe da RESEX do Unini e membro do Conselho Consultivo:

Devido à carência de pessoal, as UCs do baixo rio negro têm dificuldade de implementar um sistema eficiente de troca de informações e experiências. $O$ mosaico foi criado para suprir esta lacuna e para tornar a comunicação entre as UCs mais efetiva. Sem um sistema de comunicação efetivo entre as UCs, torna-se inviável promover a gestão integrada. A gestão integrada é pertinente para as UCs do baixo rio negro porque trata-se de um território com características e objetivos comuns de conservação. O mosaico foi criado também para dar maior visibilidade para a conservação na Amazônia, para suas dificuldades e limitações, e também para garantir um espaço de diálogo democrático e de gestão participativa (informação verbal). ${ }^{11}$

Para a gestora, o Mosaico foi pensado e constituído na região do baixo rio negro também para promover melhorias na comunicação entre os gestores das UCs. Para ela, a gestão integrada é condizente com a realidade local, uma vez que as UCs apresentam objetivos de conservação bastante comuns. Além disso, o Mosaico também foi criado para dar maior visibilidade às demandas de conservação do bioma Amazônia.

Já conforme gestor federal do ICMbio, cuja identidade será mantida sob sigilo, a pedido do entrevistado:

Os mosaicos foram criados no Brasil para promover a gestão integrada entre UCs e demais áreas protegidas, otimizar recursos, alinhar políticas, somar forças, integrar políticas de governo e garantir expertise técnica, pois as UCs isoladamente muitas vezes não contam com expertise, que pode surgir com a criação de mosaicos. Por exemplo, no mosaico, podem ser aproveitados os estudos de uma UC para subsidiar a elaboração de Planos de Manejo de outras UCs que dele fazem parte. Os mosaicos também são potenciais espaços para prevenir conflitos, ou seja, nos espaços de diálogo garantidos pelos mosaicos, é possível discutir e solucionar conflitos, evitando intervenções jurídicas e burocráticas que demandam tempo para serem finalizadas (informação verbal). ${ }^{12}$

\footnotetext{
${ }^{11}$ Entrevista concedida em 01 de agosto de 2014, em Novo Airão- Amazonas.

${ }^{12}$ Entrevista concedida em 09 de outubro de 2014, em Brasília- DF.
} 
Ainda conforme o gestor federal do ICMbio,

Além disso, o mosaico fortalece as UCs que dele participam, auxiliando na consolidação delas e impedindo a desafetação. O mosaico promove a articulação local e direciona recursos advindos da compensação ambiental. Ele aumenta a força política em prol da conservação. Recentemente, assistimos a conselhos de mosaicos lutando para impedir o desenvolvimento de atividades degradadoras em UCs, por parte do setor privado. Assistimos a essa luta e à vitória de um dos mosaicos e, como consequência positiva, ganhamos a conservação das áreas que ficaram livres da intervenção. Este é um exemplo de que os mosaicos contribuem para a conservação ambiental. Entretanto, ainda não existe uma política orientadora de mosaicos. A lei por si só não os ampara. Devido à lacuna, falta recursos para os mosaicos e isto os enfraquece. O apoio que os mosaicos recebem do Governo Federal é restrito ao lançamento de editais que visam a criação de novos mosaicos e, para dificultar ainda mais, o Governo falha no repasse dos recursos previstos nesses editais, tornando as metas de criação, implementação e gestão dos mosaicos uma tarefa árdua. Somando-se a estas dificuldades, o Governo Federal parece não ser muito favorável aos mosaicos. Talvez isto se deva ao fato de que os mosaicos vêm demonstrando atuação como força política, muitas vezes divergente dos interesses governamentais. Inclusive, o conceito de mosaico, algumas vezes, é utilizado erroneamente para subsidiar a construção de sistemas de conjuntos de UCs que, na verdade, não apresentam paralelismo algum com o modelo de mosaico recomendado pelo SNUC. Estes "falsos mosaicos" são criados concomitantemente à criação das UCs que o irão compor. Então, criam-se as UCs e paralelamente oficializa-se o mosaico, designando apenas um gestor para todas as UCs e destinando menos recursos se comparado aos recursos que seriam destinados se consideradas cada uma das UCs isoladamente. Esta prática diverge do conceito de mosaico contido no SNUC e pode ser entendida como prejudicial à conservação ambiental, pois ela acarreta na sobrecarga do gestor, bem como dificulta a implementação de ações conservacionistas, na medida em que não há recursos suficientes disponíveis. No mais, os mosaicos carecem de metodologia eficiente para sua avaliação. Isto ocorre porque os mosaicos ainda não contam com um objetivo comum definido na portaria de criação. Os mosaicos ficaram no nível das incertezas e, deste modo, não há como avalia-los. Além disso, os mosaicos ainda não contam com secretarias executivas e isto dificulta o cotidiano da gestão. Para fortalecer os mosaicos, é preciso uma atuação mais forte dos órgãos governamentais responsáveis pela coordenação do SNUC. Porém, no momento atual, o governo federal vem retirando seu apoio aos mosaicos (informação verbal). ${ }^{13}$

\footnotetext{
${ }^{13}$ Entrevista concedida em 09 de outubro de 2014, em Brasília- DF.
} 
Conforme informado pelo gestor, no Brasil, os mosaicos vêm atuando como força política em prol da conservação, apresentando ganhos concretos. Porém, eles enfrentam oposições institucionais, o que dificulta o alcance de resultados positivos. Além disso, o gestor chama atenção para o fato de que o conceito de mosaico pode estar sendo aplicado de forma equivocada na prática, trazendo consequências negativas para a conservação da biodiversidade. Além disso, o gestor enfatiza a necessidade de se avaliar os mosaicos de forma sistemática e de estrutura-los em torno de um sistema administrativo viável. Para o gestor, os mosaicos precisam de mais apoio institucional.

Ainda de acordo com o gestor do ICMbio,

\begin{abstract}
Por vezes, questiona-se acerca da criação do Mosaico do Baixo Rio Negro, por ele estar inserido dentro da área do Corredor Central da Amazônia. Este Corredor é do tipo biorregional e foi criado no âmbito do Projeto Corredores Ecológicos- PCE. Em termos conceituais, os Corredores Biorregionais e os Mosaicos apresentam muitas semelhanças. Porém, na prática, o Corredor Central da Amazônia resume-se a um projeto, se restringindo a uma delimitação de área para a destinação de recursos. Este Corredor não possui gestores, nem mesmo para integrar ações. A atuação do Corredor tem sido restrita ao repasse de recursos para a Reserva da Biosfera da Amazônia Central. A Reserva abarca o Corredor e o Mosaico do Baixo Rio Negro. A Reserva da Biosfera da Amazônia Central, diferentemente do Corredor, atua como instância de gestão, contando, inclusive com um Conselho Gestor, que também participa da gestão do Mosaico do Baixo Rio Negro (informação verbal). ${ }^{14}$
\end{abstract}

A partir das informações concedidas pelo gestor, depreende-se que para integrar a gestão entre as UCs do baixo rio negro, tornou-se necessária a implementação de um outro instrumento de gestão ambiental, diferente do Corredor Biorregional Central da Amazônia, pois este não vinha desempenhando a função de promover a gestão integrada.

\footnotetext{
${ }^{14}$ Entrevista concedida em 09 de outubro de 2014, em Brasília- DF
} 
Neste caso específico, a sobreposição das políticas de mosaico, corredor biorregional e reserva da biosfera pode ser concebida como positiva, na medida em que resultou em ações que auxiliaram na conservação ambiental e no desenvolvimento sustentável na região da Amazônia Central, como por exemplo o apoio financeiro concedido à Reserva da Biosfera pelo Corredor da Amazônia Central e a participação da Reserva no Conselho Consultivo do Mosaico do Baixo Rio Negro. O apoio financeiro à Reserva tende fortalece-la, enquanto que a participação desta no Conselho Consultivo do mosaico promove o intercâmbio de informações entre os gestores ambientais atuantes na região.

Conforme as entrevistas concedidas, os gestores governamentais atuantes na gestão do mosaico entendem que sua criação foi baseada, prioritariamente, na meta de integrar as ações entre as UCs do baixo rio negro. Além disso, ao analisar o histórico de formação do Mosaico, conclui-se que ele não corresponde ao "falso mosaico" citado pelo gestor federal, o qual surge de forma concomitante à criação de novas UCs, sendo designado apenas um gestor para administrar toda a área do mosaico, sobrecarregando-o e destinando menos recursos para as atividades de gestão das UCs. O histórico do Mosaico do Baixo Rio Negro sugere que o que ocorreu para sua formação foi a união de UCs já criadas, com o intuito de multiplicar os recursos e otimizar as ações por meio da gestão integrada.

\subsection{3- Percepções dos comunitários}

Para Kátia Cileny Veloso de Farias, Conselheira, representante da Associação dos Moradores do Rio Unini- AMORU:

O Mosaico do Baixo Rio Negro foi criado para ajudar as comunidades locais a melhorarem suas condições de vida. Pensou-se em criar este mosaico para que houvesse diálogo e compartilhamento de ações entre o Conselho do Mosaico e os Conselhos das UCs. Ele foi concebido para fortalecer as UCs e seus respectivos conselhos (informação verbal). ${ }^{15}$

${ }^{15}$ Entrevista concedida em 30 de julho de 2014, em Novo Airão- Amazonas. 
Para a comunitária, o Mosaico do Baixo Rio Negro foi concebido visando melhorar as condições de vida das comunidades locais. Em outras palavras, o Mosaico surge como uma oportunidade de aliar conservação ambiental e o desenvolvimento socioeconômico das populações residentes nas UCs do baixo rio negro.

Francisco Souza, Conselheiro, representante do FOPEC e líder comunitário, entende que:

O FOPEC participou do processo de criação do Mosaico. Para o FOPEC, o mosaico foi criado para otimizar a gestão das UCs da região, para integrar suas ações. Este foi o principal objetivo principal da criação do mosaico. A participação das comunidades locais no processo de criação do Mosaico do Baixo Rio Negro foi fomentada pela ação das ONGs que atuam na região. Os comunitários selecionaram as ONGs "de confiança" para auxiliar no processo de ampliação da participação social no âmbito do debate que discutiu a criação do mosaico. As ONGs IPÊ e FVA foram as entidades que promoveram a participação social no processo de criação do mosaico (informação verbal). ${ }^{16}$

Conforme o comunitário, a etapa inicial de criação do Mosaico contou com a participação das comunidades locais. Isto sugere que a prática de criação de UCs ou de blocos de UCs na região do baixo rio negro vem sendo invertida, se comparada às práticas que predominavam na década de 1980, caracterizadas pelo autoritarismo governamental e pela ausência de ampla participação social.

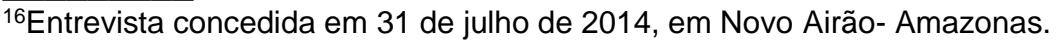




\section{CAPÍTULO 4- INSTRUMENTOS DE GESTÃO DO MOSAICO DO BAIXO RIO}

NEGRO

\section{1- O CONSELHO CONSULTIVO}

A principal instância de gestão dos mosaicos é o Conselho Consultivo. De acordo com o Decreto ํㅜ 4.340, de 22 de agosto de 2002, que regulamenta artigos da Lei do SNUC, os mosaicos deverão dispor de um conselho, com caráter consultivo e função de atuar como instância da gestão integrada das UCs que o compõem. A composição do conselho do mosaico deverá ser estabelecida na portaria que o instituir, com observância do disposto no Capítulo V- do Conselho, do Decreto ํo 4.340/2002.

Este capítulo trata dos conselhos das UCs. Portanto, o Decreto estabeleceu um paralelismo entre a composição desses conselhos e os conselhos dos mosaicos. Deste modo, o conselho do mosaico será presidido por um dos chefes das UCs que o compõem, a ser escolhido por maioria simples; a representação dos órgãos públicos deverá contemplar os três níveis da Federação e órgãos de área afins; a representação da sociedade civil deverá contemplar ONGs ambientalistas com atuação comprovada na região, comunidade científica, população residente nas UCs e em seu entorno, populações tradicionais, proprietários de imóveis localizados no interior das UCs que o compõem, trabalhadores e setor privado atuantes na região, além de representantes dos Comitês de Bacias Hidrográficas.

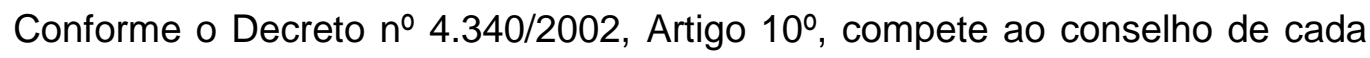
mosaico:

Elaborar seu regimento interno; propor diretrizes e ações para compatibilizar, integrar e otimizar as atividades desenvolvidas em cada UC, tendo em vista especialmente os usos nas fronteiras entre as unidades; o acesso a elas; a fiscalização; o monitoramento e a avaliação dos Planos de Manejo; a pesquisa científica e a alocação dos recursos advindos da compensação referente ao licenciamento ambiental de empreendimentos com significativo impacto e a relação com a população residente na área do mosaico. Compete ao conselho de cada mosaico manifestar-se sobre as propostas de solução para a sobreposição de unidades e manifestar-se, quando provocado por órgão executor, por conselho de UC ou por outro órgão do SISNAMA, sobre assunto de interesse para a gestão do mosaico (BRASIL, 2002). 
O conselho dos mosaicos, conforme as diretrizes legais referentes à sua composição, são instâncias de gestão multisetoriais, permitindo a ampla participação social. Devido ao caráter consultivo, os conselhos dos mosaicos não podem deliberar. Esta característica dos conselhos dos mosaicos os diferem dos conselhos das UCs, os quais poderão ter caráter consultivo ou deliberativo. Apesar de seu caráter apenas consultivo, o Decreto 4.340/2002, em seu Artigo 10ํㅡㄹ assegura aos conselhos dos mosaicos a possibilidade de manifestação sobre qualquer assunto que seja de interesse para a gestão do mosaico, conferindo ao conselho possibilidades para uma atuação ampla. Ademais, não foi estabelecida qualquer relação de hierarquia entre o conselho do mosaico e os conselhos das UCs que o compõem.

\title{
4.2- A FORMAÇÃO DO CONSELHO CONSULTIVO
}

Para Illenseer, consultor do IPÊ durante o processo de criação do Mosaico, ator participante, atualmente gestor da FUNAI e membro convidado do Conselho Consultivo do Mosaico:

O Conselho Consultivo do Mosaico foi composto, ainda que de modo informal, anteriormente à própria criação do mosaico. Porém, sua oficialização ocorreu de forma concomitante ao ato de reconhecimento do Mosaico, uma vez que a Portaria MMA no 483, de 14 de dezembro de 2010, que reconheceu o mosaico, também dispôs sobre a composição de seu Conselho Consultivo (informação verbal). ${ }^{17}$

De acordo com o Artigo $3^{\circ}$ da referida Portaria, o Conselho do Mosaico será composto por:

\begin{abstract}
Um representante das UCs federais de proteção integral; um representante das UCs federais de uso sustentável; dois das UCs estaduais; um da RDS do Tupé; um representante de um dos municípios onde estão localizadas as UCs; um representante dos povos indígenas da região; um representante do Conselho da Reserva da Biosfera da Amazônia Central; quatro representantes de organizações de base atuantes na região; um representante de ONG ambientalista atuante na região e um representante do setor privado atuante na região (BRASIL, 2010).
\end{abstract}

Ainda conforme a Portaria, o Conselho do Mosaico poderá convidar representantes de outros órgãos governamentais e não-governamentais e pessoas de notório saber para contribuir na execução de seus trabalhos.

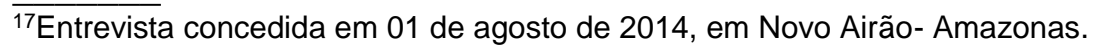


Conforme o documento intitulado "Estratégias de Formação do Conselho Consultivo do Mosaico do Baixo Rio Negro", produzido por articuladores do IPÊ para o projeto do mosaico, a base metodológica para a formação do Conselho constituiu-se dos exemplos e caminhos debatidos na Oficina de Gestão Participativa do SNUC. Conforme esta base, o processo de formação dos conselhos deve seguir etapas sucessivas de sensibilização-mobilização social, articulação institucional, realização de reuniões preparatórias, escolha e capacitação dos gestores. Ainda conforme o documento, o Conselho do Mosaico foi formado para assegurar um espaço de debate a nível regional acerca da conservação ambiental e do desenvolvimento sustentável. Ele foi constituído com o intuito de atuar de um modo mais fluido e flexível, não se restringindo apenas a promover a gestão integrada. O conselho foi criado também para empoderar as populações locais no que se refere à participação ativa no planejamento regional.

Dando prosseguimento e ainda com base no documento supracitado, para formar o Conselho, foram realizadas as etapas sugeridas pela metodologia estabelecida na Oficina de Gestão Participativa do SNUC. A ONG IPÊ conduziu as atividades, contando com o apoio de parceiros locais. A primeira atividade realizada foi a mobilização social e institucional, na qual foram mapeados os atores sociais e institucionais locais atuantes na conservação ambiental da região. Após mapear, o IPÊ realizou reuniões com os atores e instituições identificadas, nas quais foi apresentado o projeto do mosaico e realizada a etapa de sensibilização para a conservação.

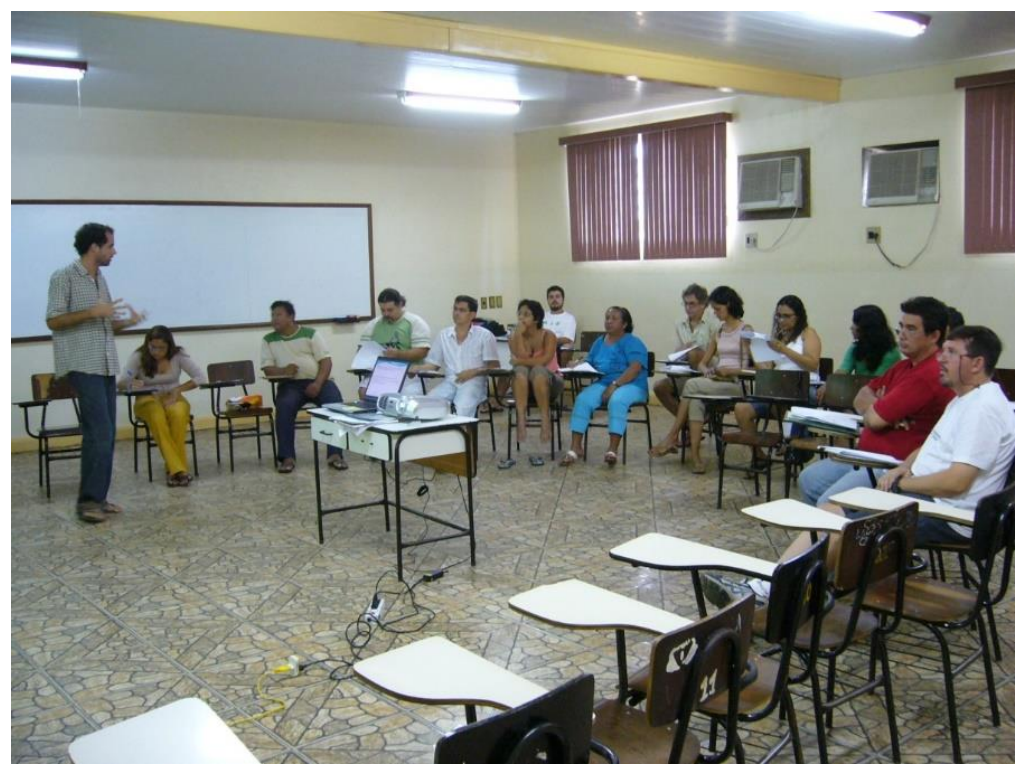

Ilustração 7- Reunião IPÊ- Parceiros realizada em maio de 2005. Local: Baixo Rio Negro/AM. Autor: Desconhecido. Fonte: www.ipe.org.br. 


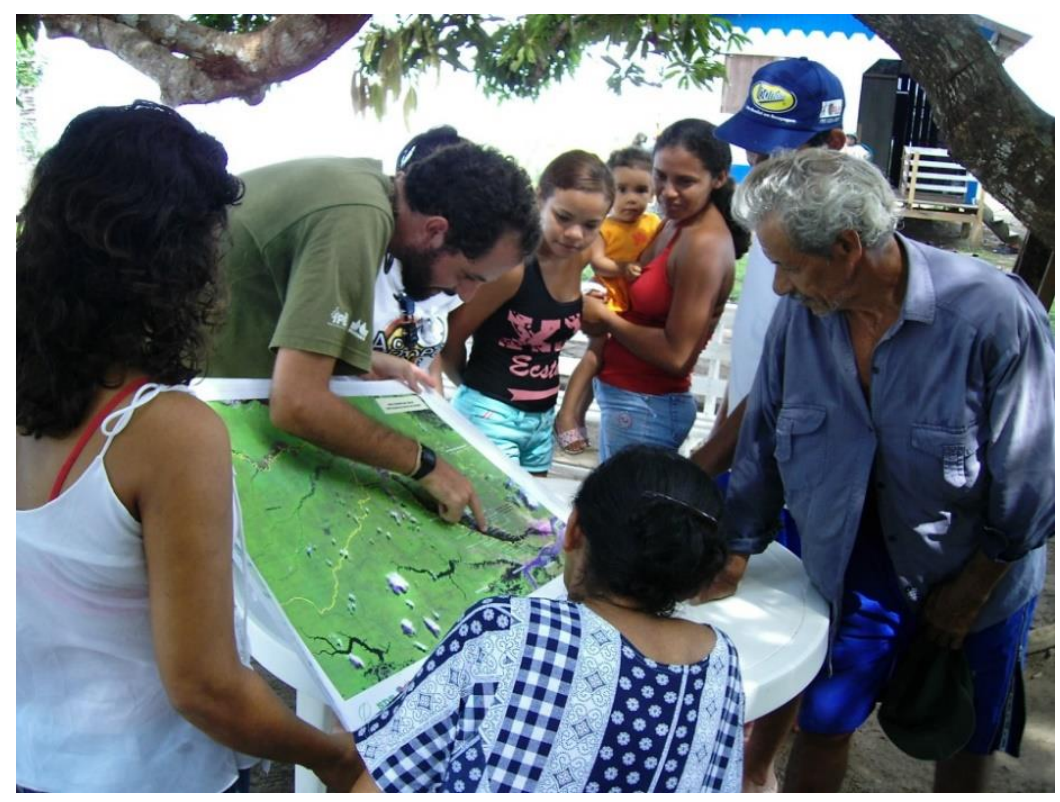

Ilustração 8- Expedição do IPÊ na margem direita do Rio Negro para mapeamento dos atores e formação de lideranças, em 2005/2006. Local: Baixo Rio Negro. Autor: Desconhecido. Fonte: www.ipe.org.br.

O documento "Estratégias de Formação do Conselho Consultivo do Mosaico do Baixo Rio Negro" cita a realização de uma primeira Oficina do Mosaico, a qual ocorreu em data anterior ao reconhecimento do mesmo. Esta Oficina fez parte da etapa reuniões preparatórias. Conforme o documento, a I Oficina do Mosaico ocorreu em agosto de 2008, tendo como objetivo principal integrar os gestores. As temáticas "Gestão Participativa" e "Desenvolvimento Territorial" serviram de base para as discussões. Nesta Oficina, surgiu o GT que iria articular a formação do Conselho. Durante a Oficina surgiram temas pertinentes ao Mosaico, como a valorização da sociobiodiversidade por meio da certificação de seus produtos e serviços.

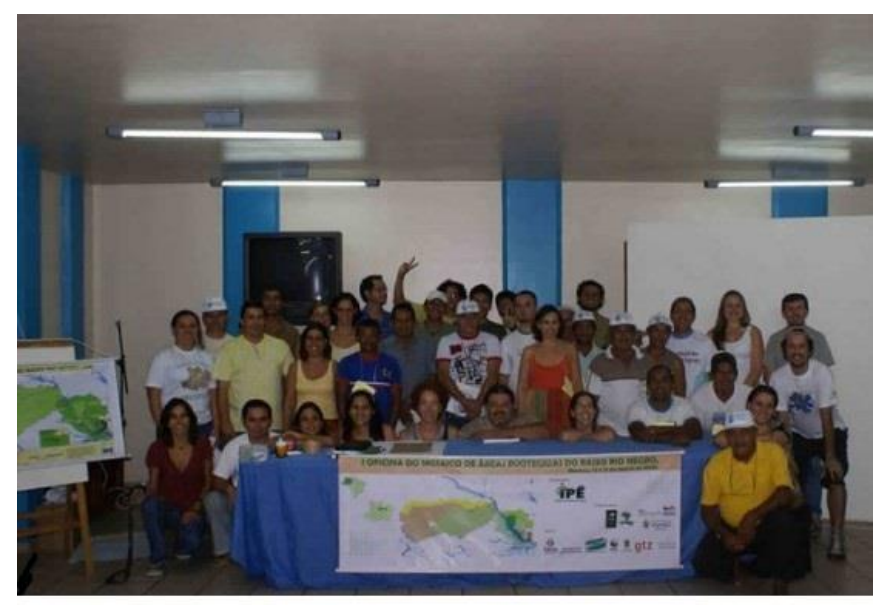

Ilustração 9- I Oficina do MBRN. Local: Baixo Rio Negro. Autor: Desconhecido. Fonte: www.ipe.org.br 
Prosseguindo, capacitaram-se os gestores que iriam compor o Conselho. Esses gestores foram capacitados nas temáticas "Gestão Participativa e Integrada" e "Desenvolvimento Territorial". Ainda conforme o documento supracitado, o Mosaico e seu Conselho foram criados para empoderar as populações locais e, com isso, garantir a elas o direito de manter seus modos de vida.

De acordo com a Ata da Reunião para a Formação do Conselho, com data de 29 de outubro de 2009, este foi formado, para seu primeiro mandato de dois anos (20102012) por seus quatorze titulares e suplentes, contando com um total de vinte e oito membros. As cadeiras titulares foram ocupadas da seguinte forma: 02 gestores de UCs federais, 02 de UCs estaduais, 01 da RDS do Tupé, 01 das SEMMAS de Novo Airão, Iranduba e Barcelos, 01 da CERBOC, 01 da base comunitária de cada sub-região do Mosaico, 01 de entidade de base dos municípios, 01 da TI Waimiri-Atroari, 01 de ONG ambientalista atuante na região e 01 do setor empresarial. Analisando a composição do Conselho, é possível afirmar que foi mantida a paridade entre representantes governamentais e não governamentais, conforme estabelecido no Decreto 4.340/2002.

Conforme a ata, a reunião contou com uma ampla participação dos atores, que somaram quarenta e oito pessoas presentes, as quais participaram representando diversas instituições, organizações e esferas de governo. Assim, estiveram presentes representantes do ICMbio, das ONGs ambientalistas IPÊ, FVA e WWF-Brasil, de comunidades locais ribeirinhas e indígenas, das associações como a Associação dos Pisicultores de Novo Airão- APINA, do setor privado como a Associação dos Operadores de Barcos de Turismo- AOBT, representantes de cooperativas locais como a Nov'Art, da SEMMA de Novo Airão, da SDS/CEUC, do Sindicato dos Trabalhadores Rurais de Novo Airão- STRNA, do Programa Waimiri-Atroari- PWA, dentre outros representantes. De acordo com este cenário, conclui-se que o processo de formação do conselho ocorreu de forma participativa.

\section{3- A ATUAÇÃO DO CONSELHO DO MOSAICO}

O Conselho vem gerindo o Mosaico, principalmente por meio de reuniões ordinárias periódicas. Normalmente, as reuniões acontecem em Novo Airão, município do Estado do Amazonas, localizado dentro da área do mosaico, sendo o principal acesso para as UCs de proteção integral: PARNA de Anavilhanas e PARNA do Jaú. O 
Conselho realizou sua nona e mais recente reunião, em 31 de julho e 01 de agosto de 2014, na Câmara de Vereadores de Novo Airão.

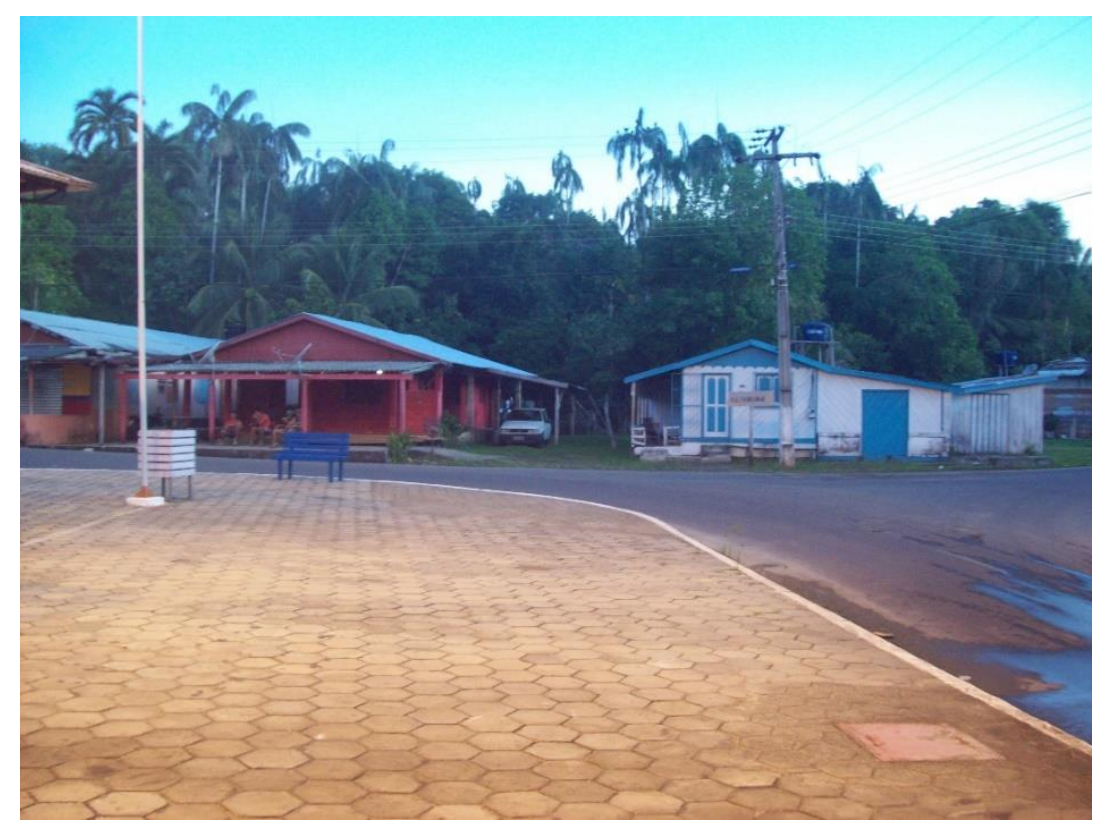

llustração 10- Novo Airão- AM. Autora: Carolina Azevedo. Agosto/2014.

Em 14 de setembro de 2011, o Conselho realizou sua primeira reunião. Desde então, as reuniões contam com uma boa participação por parte dos conselheiros e convidados. No entanto, há exceções quanto ao interesse em participar da gestão do Mosaico. Por exemplo, a representação dos indígenas da etnia Waimiri-Atroari que habitam a região do mosaico tem sido fraca, pois poucas vezes houve sua participação nas reuniões e encontros nos quais o mosaico foi discutido, conforme mencionado por gestor em entrevista concedida. Ainda, conforme consta na Ata da 8ª Reunião Ordinária do Conselho, outras instituições como a Associação dos Operadores de Barcos de Turismo- AOBT, a Associação dos Pisicultores de Novo Airão- APINA e as Prefeituras de Novo Airão e de Barcelos também vem negligenciando sua participação na gestão do Mosaico, e conforme observado na 9 ${ }^{a}$ Reunião do Conselho, os gestores sugerem a substituição destas representações por outras oriundas dos mesmos setores.

O Conselho vem gerindo o mosaico de forma participativa, conforme recomendado na Lei do SNUC e em seu Decreto Regulamentador no 4.340/2002. O caráter participativo do Conselho é evidente nas atas das reuniões ordinárias e nas respectivas listas de presença. Conforme estes documentos, participaram das reuniões do Conselho, representantes de instituições do Governo Federal, como o ICMbio e a FUNAI, do Governo Estadual, como a SDS/CEUC e ITEAM, do Poder Público Municipal, 
como a SEMMA de Novo Airão, de ONGs ambientalistas, como o IPÊ, a FVA e NSC (Natureza, Sociedade e Conservação), das comunidades locais, como a AMORU e o FOPEC, do Conselho da Reserva da Biosfera da Amazônia Central- CERBAC, do setor privado, como a AOBT, embora tenha havido pouca participação deste setor na gestão do Mosaico, dentre outros atores.

Conforme observado durante a 9ª Reunião do Conselho, o momento atual é de dificuldades para o Mosaico, visto não haver recursos financeiros para geri-lo. Devido a este cenário de impossibilidades reais, as diversas instituições envolvidas em sua gestão vem colocando em prática um tipo de "rodízio" para financiar as reuniões do Conselho, garantindo com isso a continuidade dos encontros entre os conselheiros e, com isto, assegurando a sobrevivência do Mosaico enquanto instrumento de gestão integrada.

Além disso, tem sido necessário que as instituições com cadeira no Conselho financiem a participação dos comunitários nas atividades de gestão do mosaico. Conforme observado durante a $9^{\underline{a}}$ Reunião do Conselho, às vezes, é necessário que os gestores financiem com seus próprios recursos a participação dos comunitários nas atividades de gestão do mosaico, tendo que retirar recursos dos "próprios bolsos" para isto.

Devido a ampla gama de assuntos com os quais lida e visando otimizar as atividades, o Conselho do Mosaico criou instâncias específicas de gestão. Tais instâncias são denominadas Câmaras Técnicas e, além delas, constituiu-se o Colegiado. Conforme consta em atas, foram constituídas pelo Conselho as Câmaras Técnicas de Uso Público, de Captação de Recursos, de Ordenamento Territorial e da Mineração. As Câmaras Técnicas realizam reuniões com frequência, nos períodos entre uma e outra reunião do Conselho, apresentando os resultados de seus debates e atividades para os demais conselheiros nas reuniões subsequentes do Conselho.

As Câmaras Técnicas são multisetorias, estabelecendo um paralelo com a estrutura de composição do Conselho. Conforme registrado nas atas das reuniões e percebido por meio da participação na 9 ${ }^{a}$ Reunião do Conselho, são múltiplos os temas tratados pelo mosaico, sendo estes: mineração, educação no Rio Negro, ordenamento do turismo, redelimitação e recategorização das UCs, gestão integrada, valorização da sociobiodiversidade, desenvolvimento territorial, regularização fundiária das UCs, 
manejo dos recursos naturais, conservação de espécies ameaçadas de extinção, geração de renda nas UCs de uso sustentável e no entorno do Mosaico; monitoramento da biodiversidade, compensação ambiental, gestão participativa, comunicação, divulgação do mosaico, política agrária, fiscalização ambiental, indígenas, zoneamento econômico ecológico, geração de energia, obras públicas de infraestrutura, desmatamento, educação ambiental, segurança alimentar, saneamento básico, pesquisa dentre outros.

O Conselho vem se manifestando por meio de monções. Moção significa moverse ou relaciona-se ao ato resultante da movimentação. Em termos jurídicos, e de acordo com o Dicionário Online de Português, moção significa proposta oriunda de uma assembleia, cujo teor deve ser submetido para votação pela mesma para aprovação e encaminhamento. Conforme consta na ata da primeira reunião do Conselho, na ocasião, foram elaboradas as seguintes moções: ao Comitê de Compensação Ambiental da SEMMA de Manaus, na qual solicita-se uma cadeira para o Mosaico neste Comitê; ao Departamento de Áreas Protegidas do Governo Federal, uma na qual solicita-se o envio de um analista ambiental para auxiliar na gestão do PARNA Anavilhanas e outra manifestando apoio à criação da RESEX do Rio Jauaperi, na região do Mosaico. Na primeira reunião, os conselheiros tomaram posse, expressando o seguinte juramento:

Prometo pela minha honra não medir forças para pôr em prática a gestão integrada e participativa, executar com flexibilidade, sabedoria e firmeza a honra a mim concedida de ser Conselheiro do Mosaico do Baixo Rio Negro. (Ata da 1a Reunião do Conselho)

No juramento proferido pelos novos conselheiros, a ênfase recaiu sobre o compromisso de promover a gestão integrada e participativa, o que sugere que estes são objetivos de suma importância do Mosaico.

Durante a segunda reunião do Conselho, conforme consta na ata correspondente, foi elaborada uma moção para o Projeto ARPA, na qual o mosaico convida o Programa para atuar como parceiro. Ademais, o Conselho acatou decisão favorável com relação ao envio de moção para a SEMMA de Manaus, solicitando a aprovação e implementação do Plano de Manejo da RDS do Tupé, UC integrante do mosaico, e moção endereçada ao ARPA, solicitando apoio para viabilizar as reuniões do Mosaico e para a divulgação do mesmo no ano de 2012. A demanda do Conselho obteve parecer favorável do ARPA, conforme consta na Ata da 3를 Reunião. 
$\mathrm{Na} 3^{\text {a }}$ Reunião do Conselho, de acordo com a ata correspondente, os conselheiros e demais participantes discutiram sobre a proposta do Governo Federal de construção da Usina Hidrelétrica (UEH) do Bem Querer em Roraima. Esteve presente nesta reunião representante do ICMbio de Roraima. O convidado relatou para o Conselho as principais ameaças representadas pela construção desta hidrelétrica. A proposta é que a hidrelétrica seja instalada no Rio Branco, em Roraima. O representante do ICMbio alertou os conselheiros sobre o fato do Rio Branco exercer grande influência no Rio Negro, principalmente em suas formações insulares, como as ilhas de Anavilhanas e do Jaú.

Conforme a ata, nesta reunião, o Conselho decidiu pela elaboração de Nota Técnica, para envio aos órgãos governamentais competentes, na qual seria explicada às autoridades a influência do Rio Branco sobre o Negro, bem como descritas as consequências ambientais e sociais que emergirão com a construção da UHE. No teor desta Nota Técnica, consta manifestação do Conselho, sugerindo que a competência relativa ao licenciamento ambiental da obra seja transferida do governo estadual para a federal, já que à época, o Governo de Roraima assumia posição favorável à instalação da hidrelétrica.

O caso da UHE do Bem Querer é um exemplo de problema ambiental que extrapola a Unidade da Federação-UF representada pelo estado, pois suas consequências ultrapassam as fronteiras estaduais. Para lidar com este tipo de problema transfronteiriço, as Unidades da Federação afetadas, unindo esforços, terão maiores chances de sucesso. O caso da proposta de construção da Hidrelétrica do Bem Querer demonstra que, por vezes, é necessário integrar ações não apenas no âmbito do Mosaico, mas também integrar e compartilhar a gestão com a gestão de áreas localizadas fora de seus limites, unindo forças em prol da conservação e da justiça ambiental.

Conforme relato do gestor do ICMbio, constante na ata, a proposta de construção da UHE do Bem Querer faz parte do Programa de Aceleração do Crescimento-PAC II, do Governo Federal. Porém, a proposta carece de estudos mais consistentes e, caso seja aprovada, causará significativos impactos ambientais e sociais na região do Rio Branco, como perda de praias e matas ciliares, com perda de biodiversidade devido à inundação de áreas necessária para a construção da barragem, bem como perda de área destinada à pesca artesanal para cerca de nove mil pescadores tradicionais. 
$\mathrm{Na}$ ata consta que a proposta de construção da Hidrelétrica do Bem Querer não consiste num projeto eficiente de geração de energia, visto haver previsão para que a hidrelétrica seja construída em área plana. Em 2007, o projeto foi autorizado pelo Senado Federal, mas continua em tramitação nos órgãos de governo. Ainda, consta posicionamento do Conselho, conforme o qual decidiu-se pela união à força política contrária ao projeto. Para isto, o Conselho emitiu uma Nota Técnica e uma Moção ao Ministério Público e à Casa Civil, demandando mais estudos e novas propostas para a geração de energia no Estado de Roraima. Este caso ilustra com clareza como o Mosaico vem atuando como força política favorável à conservação ambiental.

Além dos debates acerca dos projetos de geração de energia, o Conselho vem discutindo acerca da redelimitação e recategorização das UCs que fazem parte do mosaico. O caso do PAREST Rio Negro Setor Sul é um bom exemplo. Lembrando, esta UC foi redelimitada e recategorizada em março deste ano para viabilizar a criação da RDS Puranga Conquista.

Conforme analisado nas atas, o Conselho tem se posicionado de modo favorável às propostas das comunidades locais para redelimitar e recategorizar UCs de proteção integral para a categoria de uso sustentável, de forma a permitir a presença dessas comunidades nas áreas das UCs. Para redelimitar e recategorizar as UCs, o Conselho enviou moções para o INCRA, solicitando anuência, bem como para os fóruns das comunidades, parabenizando-os pela luta e vitória alcançada. No momento, o Conselho discute acerca da redelimitação e recategorização do PARNA do Jaú, visando a criação de uma nova UC da categoria de uso sustentável no Mosaico.

Por meio deste posicionamento, a atuação do Conselho vem contribuindo para a diminuição dos conflitos socioambientais existentes na região. Os conflitos socioambientais, por vezes, resultam em prejuízos para a conservação ambiental. Ao reduzi-los, o Mosaico tende a contribuir com a proteção da natureza na região do baixo rio negro. No entanto, é também um desafio para o Mosaico assegurar a exploração e o uso sustentável dos recursos naturais nas UCs de uso sustentável.

O Conselho vem buscando integrar ações com o Poder Público Estadual, para promover o desenvolvimento territorial de base conservacionista- DTBC. Consta em ata os esforços do Conselho para articular o Mosaico com programas governamentais estaduais, como por exemplo o Programa Amazonas Rural. Este Programa tem como 
meta garantir a segurança alimentar na região do baixo rio negro. No entanto, a ação permanece apenas no campo das intenções, não tendo havido nenhuma ação concreta até a momento.

Também consta nas atas a intenção do Mosaico em criar um banco de dados próprio para subsidiar suas atividades e demandas. Atualmente, conforme observado por meio de participação na 9a Reunião Ordinária do Conselho, há possibilidade do Mosaico receber recursos da Fundação Moore para garantir sua manutenção e funcionamento. No entanto, o Mosaico carece de um banco de dados que possa subsidiar a proposta a ser apesentada para a Moore. A falta de um banco de dados é mais uma das dificuldades de gestão enfrentada pelo mosaico.

O Mosaico também vem atuando para melhorar a educação na região do baixo rio negro. Segundo Pablo Pacheco, Presidente do Conselho Consultivo do Mosaico e gestor do CEUC:

O que há de mais concreto no campo da educação para o Mosaico é o Projeto Jovens, de minha autoria, como gestor da RDS do Rio Negro. O Projeto foi selecionado pelo Edital do MMA/ARPA, dentro do Programa Gestão Integrada. Os recursos serão acessados via RDS do Rio Negro, porém o projeto terá uma abrangência mais ampla, prevendo atuação dentro e no entorno do mosaico. O Projeto foi inspirado no Projeto Jovens Protagonistas, que está em desenvolvimento nos rios Unini e Jaú. A demanda para a criação do Projeto Jovens surgiu a partir da realização de diagnósticos em diversas comunidades locais, pois constatou-se a necessidade de estimular os jovens da região a participar de forma mais ativa dentro de suas comunidades, como por exemplo, a necessidade de incentivá-los a participar das associações comunitárias. O Projeto Jovens, em andamento no Unini e Jaú, não abrange toda a área do Mosaico, concentrando-se em UCs específicas. O novo projeto prevê não somente abrangência na escala do Mosaico, como também em seu entorno. O projeto já conta com a adesão de cinco UCs do Mosaico e prevê a participação de dezesseis atores do Mosaico no desenvolvimento de suas atividades. O objetivo principal do Projeto é promover o intercâmbio de experiências entres os jovens das diferentes UCs que compõem o Mosaico e do entorno, com a finalidade de conhecer as principais pautas abordadas pelo público jovem do Mosaico e direcionar ações. A pedagogia na qual será baseada o projeto será referente à educação de similares. Conforme esta pedagogia, serão agrupados jovens que tenham modos de vida similares para a troca de experiências. Apesar das dificuldades impostas pela geografia da região, não serão medidos esforços para agrupar os jovens do baixo rio negro, visando o desenvolvimento do projeto (informação verbal). ${ }^{18}$

\footnotetext{
${ }^{18}$ Entrevista concedida em 01 de agosto de 2014, em Novo Airão- Amazonas.
} 
Conforme descrito pelo gestor da RDS do Rio Negro e do Mosaico, o novo Projeto Jovens será realizado de forma integrada no âmbito do Mosaico, representando um dos primeiros passos concretos da gestão integrada e compartilhada do Mosaico do Baixo Rio Negro.

Conforme análise das atas das reuniões ordinárias, o Conselho da Reserva da Biosfera da Amazônia Central- CERBAC vem participando de forma ativa da gestão do Mosaico, tendo estado presente na maior parte das reuniões do Conselho e também atuando de forma concreta na região. Consta na ata da 4a reunião do Conselho informação de que foi empreendida uma vistoria pelo CERBAC na área destinada à implantação de uma cidade universitária no baixo rio negro, com a finalidade de avaliar a situação dos fragmentos florestais que restam no local, conforme sugerido pelo Conselho do Mosaico.

Conforme consta em ata do Conselho do Mosaico, a área destinada à cidade universitária está localizada dentro do Mosaico e, portanto, dentro da Reserva da Biosfera. O empreendimento vem sendo concebido pelos gestores do Mosaico como propulsor do avanço do desmatamento na região. O CERBAC e o Conselho do Mosaico buscam unir forças para tentar reduzir o desmatamento que vem sendo causado pelo projeto da cidade universitária, gerindo a região de modo integrado.

Nas atas das reuniões, consta que o Conselho vem debatendo sobre a ameaça representada pela mineração na área do Mosaico. Atualmente, a região do baixo rio negro vem sofrendo fortes ameaças ambientais e sociais provenientes do setor da mineração, principalmente em razão da exploração da areia nos leitos dos rios. Conforme observado por meio de participação na 9aㅡ Reunião do Conselho, o Mosaico irá propor ao Ministério Público Federal o estabelecimento de zoneamento ecológico econômico para a região, visando restringir os empreendimentos mineradores a determinadas áreas, onde é possível mitigar os passivos ambientais e sociais. Conforme observado, as ameaças provenientes do setor da mineração são mais latentes na região do PAREST Rio Negro Setor Norte.

A conservação de espécies ameaçadas de extinção também é tema tratado pelos gestores do Mosaico. Atualmente, conforme consta nas atas, a mais significativa preocupação manifestada pelos conselheiros refere-se à proteção do boto-cor-de-rosa, um tipo de golfinho de águas fluviais. Esta espécie pertence à ordem dos cetáceos e à 
classe dos mamíferos. Cientificamente, a espécie é denominada Inia geoffrensis. Sua distribuição geográfica abrange as bacias dos rios Amazonas e Orinoco. Conforme classificação da Internacional Union for Conservation of Nature (IUCN), seu estado de conservação é insuficiente (IUCN, 2014).

Conforme observado em reunião do Conselho, no Rio Negro, foram construídos flutuantes para a exploração turística com botos. No entanto, este tipo de atividade vinha sendo desenvolvida de forma desordenada, com prejuízos para a conservação da espécie. Os administradores dos flutuantes não disciplinaram os horários e quantidades referentes à alimentação dos botos, nem mesmo estabeleceram locais seguros para a instalação dos mesmos. Alguns flutuantes foram instalados próximos a postos de abastecimento de embarcações, atraindo os cetáceos para locais poluídos.

Conforme observado, durante a 9a Reunião do Conselho, os gestores do Mosaico demandaram das várias UCs ações mais firmes com relação ao ordenamento do turismo com botos na região. O exemplo a ser seguido é o caso de Anavilhanas, onde os gestores foram exitosos em ordenar a atividade. Atualmente, o flutuante de Anavilhanas encontra-se instalado em local adequado à conservação do boto, tendo sido disciplinado quanto ao horário e quantidade de alimentação dos botos e número de visitantes. No caso ilustrado, percebe-se que no âmbito do Mosaico ocorre a troca de experiências entre os gestores. Neste caso específico, a experiência de Anavilhanas tende a influenciar de modo positivo os gestores das demais UCs com relação ao ordenamento do turismo com botos. 


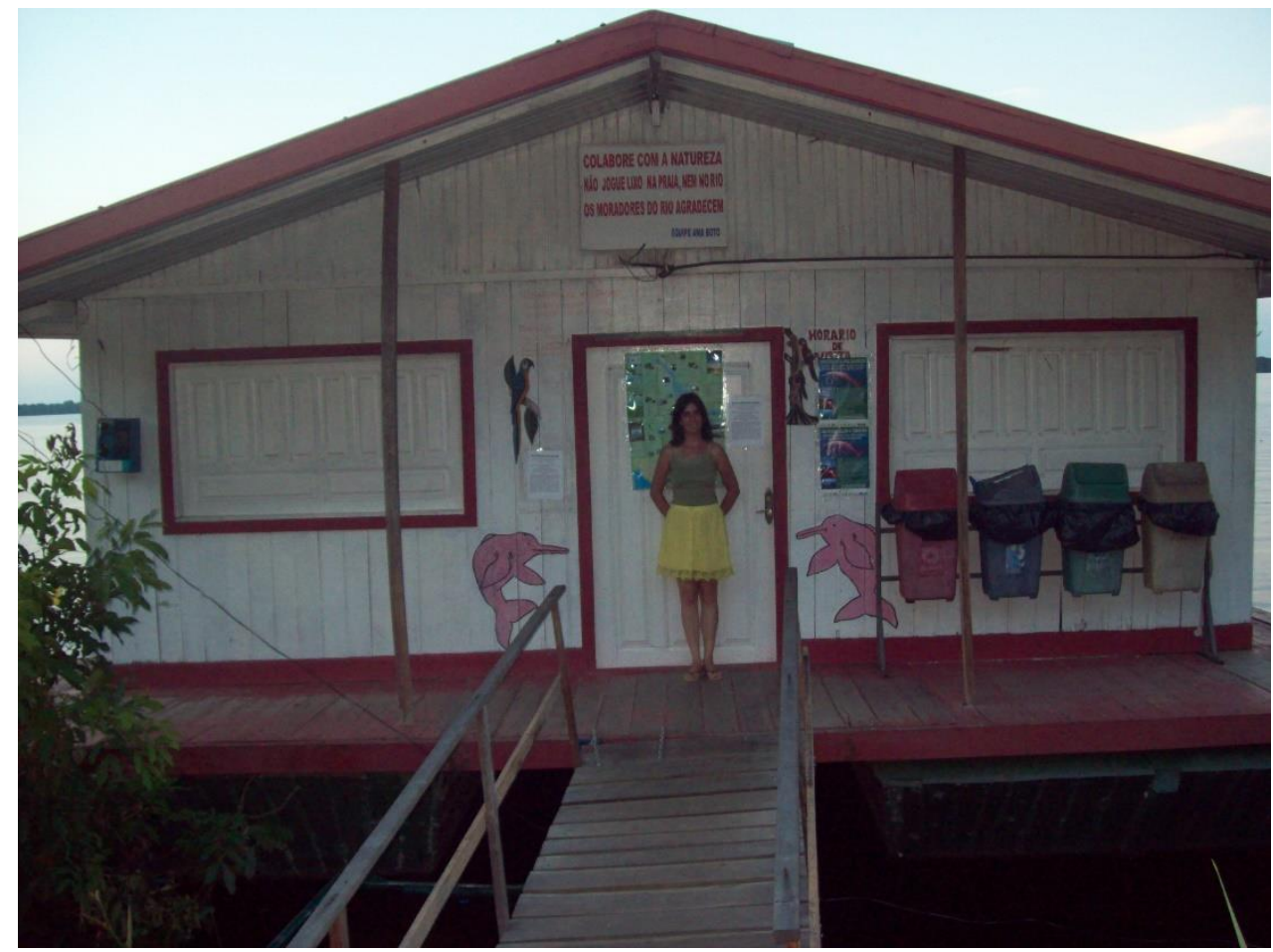

Ilustração 11- Flutuante do PARNA de Anavilhanas. Novo Airão/AM. Agosto/2014. Autora: Carolina Azevedo.

O Centro de Visitantes- CV é outro tema relacionado com o turismo na região do baixo rio negro, o qual é amplamente debatido pelo Conselho do Mosaico, conforme observado em participação em reunião. Os conselheiros buscam unir esforços para implantar o Centro em Novo Airão, município considerado o "coração do Mosaico". Os gestores pretendem utilizar o Centro para divulgar o Mosaico.

Conforme observado, o posicionamento do Conselho com relação à localização futura do Centro diverge das determinações do ICMbio de instalar o CV no município de Manaus. Devido a este conflito de interesse, o Conselho decidiu durante a 9 ${ }^{\underline{a}}$ Reunião pelo envio de moção ao ICMbio, contendo o apoio dos vereadores de Novo Airão, solicitando a implantação do CV em Novo Airão. Nesta reunião, os gestores do Mosaico dividiram tarefas para pôr em prática esta reivindicação, compartilhando atividades de gestão.

Ademais, o Conselho vem atuando na conservação do patrimônio histórico e cultural da região do baixo rio negro. Recentemente, o Instituto do Patrimônio Histórico e Nacional- IPHAN compartilha esta responsabilidade com o Mosaico, dele solicitando apoio para o tombamento das ruínas de Airão Velho. Conforme a ata da 9 ${ }^{\underline{a}}$ Reunião do Conselho, o Mosaico decidiu por apoiar o IPHAN, e no momento o processo de tombamento está tramitando. Este caso demonstra que o Mosaico vem compartilhando 
a gestão da região do baixo rio negro com órgãos governamentais de áreas afins, unindo forças também em prol da preservação do patrimônio histórico e cultural do baixo rio negro.

Outro exemplo de compartilhamento da gestão no âmbito do Mosaico é o planejamento dos cursos de guias e condutores turísticos do PARNA Anavilhanas. Conforme informações coletadas na 9a Reunião do Conselho, há pretensão dos gestores de Anavilhanas em assegurar vagas para guias e condutores de outras UCs do Mosaico nos cursos, como o PARNA Jaú e a RDS do Rio Negro.

Foi observado também por meio da participação em reunião do Conselho que o Mosaico troca experiências com outros mosaicos, em especial com o Mosaico Central Fluminense, exemplo de luta e conquista política no campo da conservação ambiental. Este intercâmbio é promovido por meio da participação de gestor do Mosaico do Baixo Rio Negro nas reuniões do Mosaico Central Fluminense. A troca de experiências entres os mosaicos é importante para compilar informações de gestão de modo a aprimorá-la, bem como para ampliar a força política dos Mosaicos.

Para finalizar, conforme observações, durante a 9aㅗ Reunião do Conselho, foram dados informes sobre uma possível parceria entre o Mosaico e a Fundação Gordon e Betty Moore, visando assegurar recursos financeiros para o Mosaico. A Fundação é a principal fonte financiadora da ONG ambientalista atuante na região do baixo rio negro, FVA. Esta ONG vem participando de forma consistente na gestão do mosaico e será por meio dela que será apresentada a proposta do Mosaico para a captação dos recursos da Fundação. Durante a reunião, os gestores procederam à revisão do Plano de Ação do Mosaico para subsidiar proposta a ser apresentada para a Moore, pois, conforme entendimento proferido pelos Conselheiros, o Plano é muito extenso, não havendo orçamento para contemplar todas as suas ações. O Conselho buscou ser "realista" e adequar o "mapa dos sonhos" às condições reais.

Segundo mencionado pela FVA na 9aㅗ Reunião do Conselho, a prioridade para a aplicação dos recursos serão o fortalecimento da governança no Mosaico e das políticas públicas nele aplicadas, bem como a garantia dos direitos coletivos das comunidades residentes, o manejo dos recursos naturais, a geração de renda e a capacitação para a gestão integrada. Além da possibilidade de repasse de recursos financeiros ao Mosaico 
pela Fundação Moore, foi citada também a possibilidade de uma parceria com a Fundação Vale.

Ainda conforme observações coletadas na 9ª Reunião do Conselho, com relação à avaliação de efetividade, o Conselho manifestou anuência para participar de estudo a ser conduzido pela WWF- Brasil. O estudo da ONG ambientalista irá verificar a efetividade da gestão em diversos mosaicos brasileiros. Pretende-se, com isto, que os resultados que serão coletados sirvam para subsidiar o Mosaico no aprimoramento de sua gestão. Além da participação em estudo da WWF- Brasil, o Mosaico intenciona ampliar e dar continuidade à aplicação do Sistema de Indicadores de Sustentabilidade em Unidades de Conservação- SISUC.

Desenvolvido pela ONG socioambientalista ISA, o SISUC é uma metodologia de monitoramento das ações desenvolvidas nas UCs, visando conhecer qual caminho está sendo percorrido, quais os pontos positivos e negativos na gestão da UC para a busca de melhorias. Atualmente, o SISUC é aplicado em seis UCs do Mosaico, a saber: PARNA Jaú e Anavilhanas, RESEX do Unini, RDS do Rio Negro, PAREST Rio Negro Setor Sul e Setor Norte (SISUC, 2014).

Conforme debatido na 9aㅡ Reunião, a parceria para a aplicação do SISUC nas seis UCs do Mosaico terminará neste ano de 2014. O MBRN estuda sobre a possibilidade de transferência institucional para a manutenção do SISUC nas seis UCs participantes, bem como para ampliar sua cobertura para todas as UCs do Mosaico. No entanto, alguns Conselheiros presentes não aderiram à ideia. Eles alegaram que o Mosaico não possui personalidade jurídica, o que o impossibilita de ser parte em uma transferência institucional. 


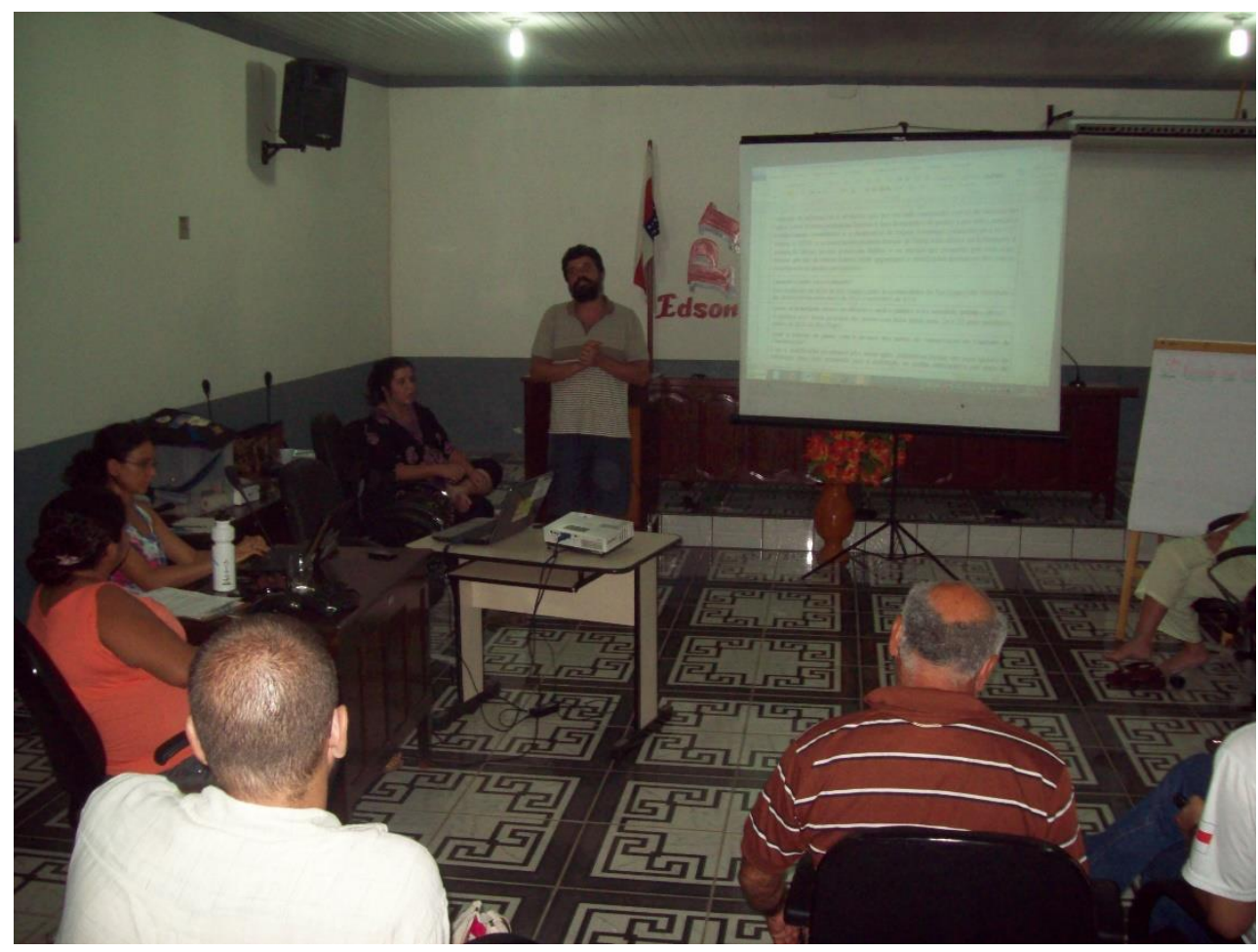

Ilustração 12- 9 ${ }^{\text {a }}$ Reunião Ordinária do Conselho do Mosaico. Novo Airão/AM. Autora: Carolina Azevedo. Agosto/2014.

Concluindo, conforme demonstram as atas, as reuniões ordinárias do Conselho ocorrem com frequência, em intervalos de 3 a 6 meses. Além dessas, ocorrem também as reuniões das Câmaras Técnicas. Conforme informações constantes nas atas, as reuniões do Conselho contam com ampla participação dos atores envolvidos na gestão do Mosaico. Deste modo, apesar da falta de recursos próprios, o Mosaico vem sucedendo na realização de suas reuniões o que demostra força de vontade para trabalhar em prol da conservação.

O Mosaico ainda está "vivo", em parte, em razão do empenho de seus gestores na luta pela conservação ambiental e pelo desenvolvimento sustentável da região do baixo rio negro. Uma das principais dificuldades do Mosaico é a disponibilidade de recursos financeiros. O Mosaico conta com significativa dedicação e credibilidade por parte de seus gestores, conforme observado por meio de participação em reunião do Conselho. Os recursos financeiros que serão disponibilizados para o Mosaico pela Fundação Moore tenderão a fomentar seu funcionamento, auxiliando o Mosaico na concretização de atividades previstas no Plano de Ação. 


\title{
4.4- NO QUE CONSISTE O MOSAICO DO BAIXO RIO NEGRO?
}

\subsection{1- Percepções dos atores governamentais e não-governamentais}

De acordo com gestor federal da área de mosaicos do ICMbio, que não consentiu em ser identificado:

O Mosaico de Áreas Protegidas é gestão integrada, é a união de forças para o alcance de objetivos comuns. O mosaico é a otimização de recursos, alinhamento das diversas políticas de governo e compartilhamento de expertise técnica. O mosaico é o tipo do olhar mais abrangente, que extrapola a UC (informação verbal). ${ }^{19}$

Já Priscila Santos, gestora do ICMbio, Chefe do PARNA de Anavilhanas e membro do Conselho Consultivo do Mosaico entende que:

\begin{abstract}
O mosaico é uma estratégia de maximizar oportunidades e pensar o território no nível macro. É união de forças favorável à gestão das UCs. É a ideia do coletivo ser mais forte que a unidade. É estratégia coletiva para fortalecer as UCs. O mosaico é instrumento de ordenamento territorial, dentro de uma perspectiva regional. Além disso, o mosaico é espaço de resistência política frente às ameaças à conservação ambiental e aos direitos das comunidades locais. O mosaico visa executar a Política Nacional de Meio Ambiente. O Mosaico do Baixo Rio Negro é uma potencialidade, pois possui status internacional por fazer parte da Reserva da Biosfera da Amazônia Central e devido ao fato de duas das UCs do Mosaico serem consideradas Patrimônios da Humanidade. Além de ser instância de gestão integrada, o mosaico é um espaço que oferece maior peso para as demandas específicas das UCs (informação verbal). ${ }^{20}$
\end{abstract}

Para Ana Luiza Figueiredo, gestora do ICMbio, Chefe da RESEX do Unini e membro do Conselho Consultivo do Mosaico:

Além de ser instância de gestão integrada, o Mosaico é um espaço que oferece maior peso para as demandas específicas das UCs. No Mosaico do Baixo Rio Negro, as demandas das UCs são levadas para as reuniões do Conselho, onde são registradas em moções de autoria coletiva, endereçadas às instituições competentes, intensificando a voz das UCs. Somando-se a este aspecto, o mosaico representa um fórum de diálogo, onde é possível trocar experiências sobre a gestão de UCs. Este intercâmbio permite aos gestores a aquisição de novos conhecimentos, que são úteis para o aprimoramento da gestão nas UCs individualizadas, ou seja, aproveita-se os exemplos das boas práticas apresentados no espaço do mosaico (informação verbal). ${ }^{21}$

\footnotetext{
${ }^{19}$ Entrevista concedida em 09 de outubro de 2014, em Brasília- DF.

${ }^{20}$ Entrevista concedida em 01 de agosto de 2014, em Novo Airão- Amazonas.

${ }^{21}$ Entrevista concedida em 02 de agosto de 2014, em Novo Airão- Amazonas.
} 
Nesta mesma linha, Clarisse Bassi, gestora da SEMA de Novo Airão e membro do Conselho Consultivo do Mosaico, afirma que:

O Mosaico de Áreas Protegidas é muito mais que a área geográfica que abarca. É união de forças. O mosaico fortalece as organizações de base e cede espaço para os movimentos comunitários. É espaço que garante a discussão entres os distintos setores. No caso do Mosaico do Baixo Rio Negro, é fórum de debate e ação para promover o desenvolvimento territorial da região (informação verbal). ${ }^{22}$

Illenseer, gestor da FUNAI, anteriormente consultor do IPÊ e participante ativo no processo de criação do Mosaico do Baixo Rio Negro e atualmente membro convidado do Conselho Consultivo do Mosaico entende que:

O MBRN é a soma de partes dinâmicas. O processo de mudança na conformação do território na região do baixo rio negro é muito rápido, pois são frequentes as ameaças representadas pelas invasões de terras e pela mineração, por exemplo. Somando-se a esta ideia, existem diferentes concepções de mosaico na região. Para os pescadores, o que existe é um "mosaico da pesca", um mapa da pesca, e não um mosaico ou paisagem formada por um conjunto de UCs. O Mosaico do Baixo Rio Negro é essencialmente um conjunto de pessoas, pois anteriormente à definição das UCs que dele fariam parte, elaborou-se o mapa dos atores atuantes na região e agrupou-os com o intuito de promover a gestão integrada e compartilhada na região. Este grupo começou a pensar sobre o desenvolvimento territorial de base conservacionista para a região, mesmo antes da definição da área que seria abarcada pelo Mosaico. Somando-se a este aspecto, o Mosaico já era uma identidade única, antes mesmo de seu reconhecimento. Isto porque a região compartilha a mesma história de colonização e também porque suas UCs preocupam-se com temas comuns. O Mosaico do Baixo Rio Negro é algo coletivo que sempre existiu na região, pois os sindicatos, as associações, os extrativistas e demais atores nela atuantes sempre interagiram entre si. Nas discussões realizadas para a construção oficial do mosaico, debateu-se se realmente seria positiva a formalização deste Mosaico, pois havia entre os gestores o receio de "engessar" uma dinâmica coletiva que já ocorria de modo natural no baixo rio negro. Porém, com o reconhecimento, o Mosaico ampliou as possibilidades de interação entre os atores, tornando-se um espaço para o debate de questões para as quais não havia abertura, como a redelimitação do PAREST Rio Negro Setor Norte. Também, o Mosaico do Baixo Rio Negro é interação com o entorno das UCs, pois no momento, o Conselho propõe pensar sobre as atividades que são desenvolvidas na região metropolitana, de modo a buscar soluções para os impactos ambientais e sociais negativos que são gerados por essas atividades na área do Mosaico (informação verbal). ${ }^{23}$

\footnotetext{
22Entrevista concedida em 01 de agosto de 2014, em Novo Airão- Amazonas.

${ }^{23}$ Entrevista concedida em 01 de agosto de 2014, em Novo Airão- Amazonas.
} 


\title{
Para Pablo Pacheco, Presidente do Conselho Consultivo e gestor do CEUC:
}

\begin{abstract}
O Mosaico do Baixo Rio Negro é um instrumento legal no qual assegura-se a liberdade de expressão de órgãos governamentais, não governamentais e da sociedade civil. O Mosaico recebe muito apoio dos comunitários da região. Seu Conselho Consultivo consiste num espaço de atualização de demandas, onde discute-se a possibilidade de "atacar" ameaças. O Mosaico é espaço destinado às reivindicações da sociedade civil. Ele foi formalizado para atender as demandas do público ribeirinho que reside dentro e no entorno das UCs (informação verbal). ${ }^{24}$
\end{abstract}

Segundo Francisco Aguinaldo, Conselheiro e gestor do Instituto de Terras do Amazonas- ITEAM:

No âmbito do Mosaico, são discutidas questões que envolvem os mais altos níveis de poder, como governadores de estado, Ministério Público FederalMPF e Tribunais de Contas- TCU. A redelimitação e recategorização do PAREST Rio Negro Setor Norte, que culminou na criação da RDS Puranga Conquista, consiste num exemplo de atuação do Mosaico em questões de maior complexidade burocrática e jurídica. O Mosaico vem tratando de temas complexos de forma responsável e com comprometimento e, para isto, a instância coletiva vem tentando envolver o maior número possível de atores para dar voz a todos os setores afetados e unir forças para alcançar os resultados almejados (informação verbal). ${ }^{25}$

Para Marco Antônio, consultor do IPÊ e membro do Conselho:

O MBRN é uma área enorme com uma identidade comum. É um território que compartilha características. É a possibilidade de trabalhar em conjunto para alcançar objetivos comuns de conservação ambiental e desenvolvimento sustentável. O MBRN é um modelo de gestão de áreas protegidas que poderá ser replicado em outras regiões. É espaço para a troca de informações. Por meio do fórum do mosaico, as UCs que dele fazem parte mantem-se informadas sobre o que está ocorrendo na região como um todo. O mosaico é um espaço muito importante para a comunicação entre os gestores das UCs e demais atores. Porém, os mosaicos são negligenciados pelas esferas de governo e também por outros atores. Não é concedida aos mosaicos a devida importância (informação verbal). ${ }^{26}$

\footnotetext{
${ }^{24}$ Entrevista concedida em 01 de agosto de 2014, em Novo Airão- Amazonas. ${ }^{25}$ Entrevista concedida em 01 de agosto de 2014, em Novo Airão- Amazonas.

${ }^{26}$ Entrevista concedida em 31 de julho de 2014, em Novo Airão- Amazonas.
} 


\subsection{2- Percepções dos comunitários}

Para a comunitária Kátia Cileny Veloso de Farias, Conselheira e representante da Associação dos Moradores do Rio Unini- AMORU:

O Mosaico é um parceiro das comunidades locais na luta por seus direitos. É instância de apoio às reivindicações comunitárias. O Conselho do Mosaico articula com os Conselhos das UCs para atender as demandas do público ribeirinho. O Mosaico é também um apoio para os Conselhos das UCs. Quando os Conselhos das UCs não conseguem resolver um problema, este é levado para o Conselho do Mosaico. O que o Conselho das UCs não consegue resolver, o Conselho do Mosaico resolve. Deste modo, ele fortalece os Conselhos das UCs ao apoia-los. O Mosaico é a gestão compartilhada entre FVA, IPÊ, SDS/CEUC, ICMbio, Sindicatos, Associações de Pescadores, SEMMAS, comunitários, dentre outros atores. O Conselho é um espaço para conscientizar sobre a importância da conservação ambiental, que é importante para os comunitários, pois é preciso preservar para garantir recursos para as gerações atuais e futuras (informação verbal). ${ }^{27}$

Conforme explicitado pela comunitária, o Conselho do Mosaico tem tido uma atuação mais forte que os Conselhos das UCs individualizados, pois para ela, o que os Conselhos das UCs não conseguem resolver é levado ao Conselho do Mosaico, que, normalmente, busca uma solução de forma mais eficiente.

Francisco Souza, representante do FOPEC, membro do Conselho Consultivo do Mosaico e líder comunitário, concebe o Mosaico como sendo:

Gestão de pessoas para pessoas. Em outras palavras, o Mosaico é uma instância composta por "pessoas" e não por "funcionários", ou seja, por indivíduos sensibilizados com relação à situação das comunidades locais que residem dentro das UCs. É gestão compartilhada e participativa, com sensibilidade. O Mosaico vai em busca de soluções oficiais e extra oficiais para tentar solucionar os conflitos de interesse existentes na região. Como o Mosaico do Baixo Rio negro é seu quadro de gestores, "pessoas sensibilizadas" e comprometidas com a causa da conservação ambiental e do desenvolvimento sustentável, e não possui recursos próprios, o Mosaico poderá ter seu funcionamento prejudicado, caso haja troca de gestores. Apesar das potencialidades do Mosaico, o Governo Federal não compreende sua importância. Os mosaicos não representam apenas mais um conselho. Os mosaicos são "os conselhos" em termos de importância, pois é o conselho dos mosaicos que transmite confiança, que de fato buscam soluções. É onde os comunitários possuem voz. É união de forças. O Mosaico do Baixo Rio Negro tem praticado o intercâmbio com outros mosaicos e tem-se percebido que os mosaicos, no geral, funcionam como instância de gestão compartilhada, onde a força política é maior. Os mosaicos representam uma força de resistência perante o governo e, por isso, não tem recebido muita atenção deste setor (informação verbal). ${ }^{28}$

${ }^{27}$ Entrevista concedida em 30 de julho de 2014, em Novo Airão- Amazonas.

${ }^{28}$ Entrevista concedida em 31 de julho de 2014, em Novo Airão- Amazonas. 
Assim como para a comunitária Kátia Cileny, para o comunitário Francisco Souza, o Conselho do Mosaico tem atuado de forma mais eficiente que os Conselhos das UCs, pois para ele, o Mosaico é "o Conselho" em termos de importância, sendo também a instância que vem transmitindo mais confiança, na visão dos comunitários.

Conforme observado na 9a Reunião, o Conselho Consultivo ainda discute sobre o que de fato é o Mosaico, na tentativa de definir seu papel na gestão do território do baixo rio negro. Nesta reunião, foram colocadas perguntas aos gestores, como: O que é o Mosaico? Para que serve? e O que deve ser feito para atingir seus objetivos? $\mathrm{O}$ Conselho debateu essas questões, concluindo que o mosaico é gestão integrada, instância para a troca de experiências e para a prática da gestão compartilhada. Conforme observado, o Conselho concebe o Mosaico como um espaço legal que permite a tomada de decisões por meio de negociações entre os distintos setores; que é espaço para promover a conservação ambiental, para debater as questões pertinentes ao território no nível macro da região e que ele também é espaço para fortalecer as demandas no nível político e para garantir a comunicação entre os atores.

Dentre as atividades que devem ser realizadas para que o mosaico alcance seus objetivos, foram citadas na reunião: a organização de seus recursos humanos e de suas demandas, criando-se uma Secretaria Executiva; incrementar a articulação entre os atores; fortalecer os movimentos de base; revisar o Plano de Ação, tornando-o estratégico; envolver os municípios; melhorar a divulgação do Mosaico; aprimorar a comunicação entre seus gestores; ampliar o monitoramento nas UCs; tornar a força política instantânea e envolver as Tls e os Territórios Quilombolas. 


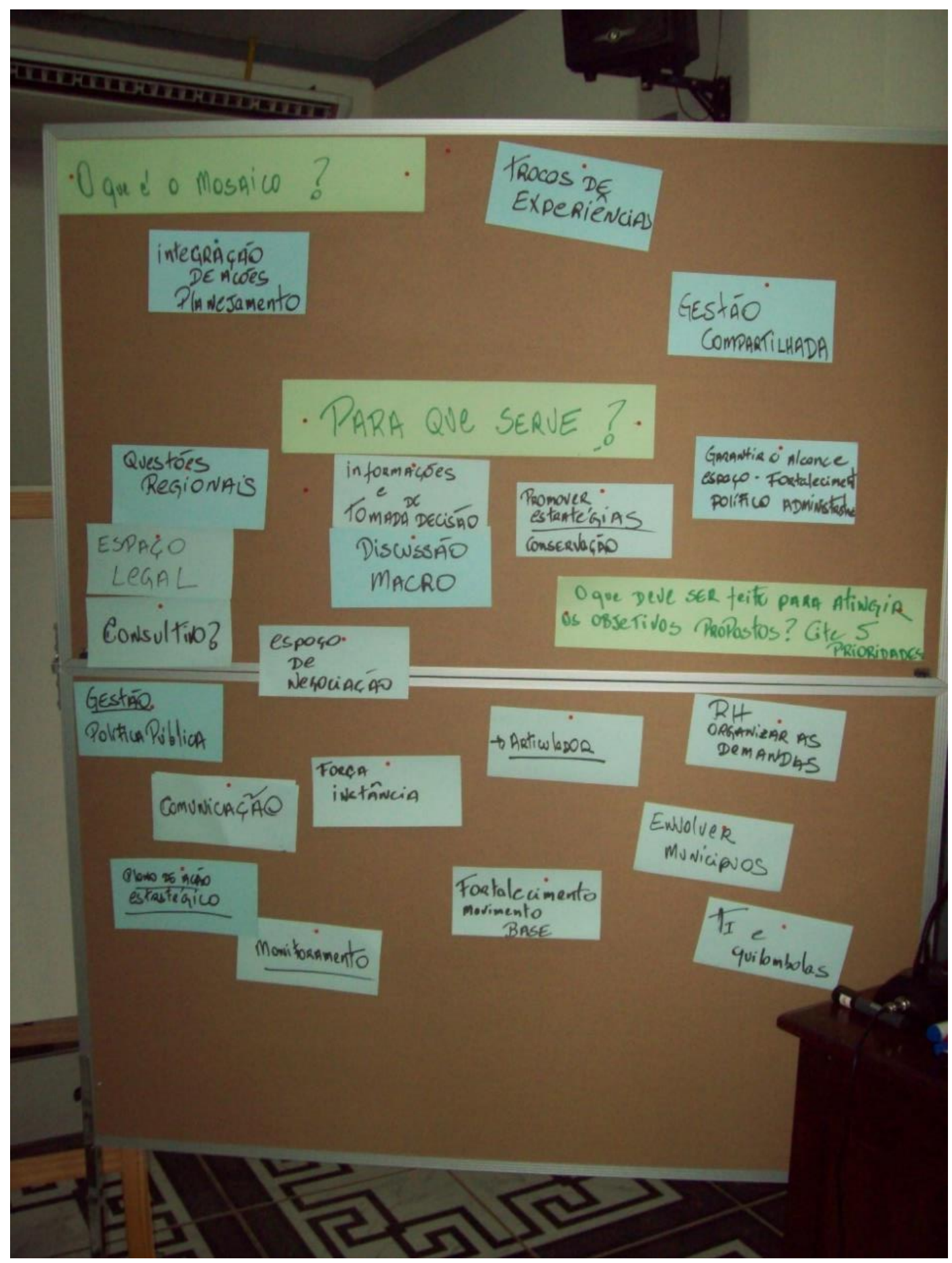

Ilustração 13- Painel Temático da $9^{a}$ Reunião do CCMBRN. Novo Airão/AM. Autora: Carolina Azevedo. Agosto/2014. 


\section{CONCLUSÕES}

As áreas protegidas são a principal e mais disseminada estratégia de proteção à natureza. Em seu início, no século $\mathrm{XIX}$, as áreas protegidas eram criadas com o objetivo de proteger sítios raros, grandiosos e com significativa beleza cênica. Com o passar do tempo, as áreas protegidas agregaram novos objetivos e uma multiplicidade de categorias surgiu para atender às novas demandas (DRUMMOND et al., 2010). Esta dinâmica está espelhada na Lei do SNUC, criada em 2000. Este normativo estabelece o Sistema Nacional de Unidades de Conservação, constituído de UCs federais, estaduais e municipais pertencentes a dois grupos distintos: de proteção integral e de uso sustentável. Cada grupo é formado por um conjunto diversificado de categorias de UCs.

O histórico das áreas protegidas no Brasil e no mundo evidencia o estabelecimento dos espaços especialmente protegidos de forma isolada uns dos outros na paisagem. A gestão individualizada para cada área protegida acompanhou o isolamento geográfico das mesmas. Para Ganem (2011), a estratégia de conservação da natureza baseada em áreas protegidas isoladas tem se mostrado insuficiente. Há problemas neste sistema, sobretudo no que se refere ao processo de fragmentação florestal. Os fragmentos isolados, que se tornaram áreas protegidas, não conseguem atingir seus objetivos de conservação, principalmente devido ao isolamento.

A dissociação das áreas protegidas do restante da paisagem traz como consequência a diminuição das taxas de sobrevivência de espécies da fauna e da flora que nelas encontram seus habitats. Isto porque, frequentemente, os fragmentos florestais que correspondem às áreas protegidas são circundados por uma matriz inóspita ao movimento da biota, o que dificulta o acesso a recursos e os processos reprodutivos de diversas espécies. Além disso, o modelo de distribuição de áreas protegidas no espaço geográfico de forma isolada umas das outras trouxe consigo a gestão também individualizada e dissociada do entorno. Este modelo de gestão também vem apresentando problemas, visto que as atividades desenvolvidas no entorno das áreas protegidas exercem influência no interior das mesmas (GANEM, 2011).

Na década de 1960, Kenton Miller desenvolveu a Gestão Biorregional. O modelo proposto por Miller recomenda que a gestão de áreas protegidas seja conduzida de forma integrada com seu entorno e que seja participativa, envolvendo diversos atores 
sociais. A Gestão Biorregional foi formulada como uma tentativa para superar os problemas relacionados com 0 isolamento das áreas protegidas e com a individualização da gestão (ARRUDA, 2006). A Lei do SNUC, criada em 2000, inovou o campo da política ambiental brasileira ao recomendar instrumentos baseados no modelo de Gestão Biorregional. Correspondem a esses instrumentos a Reserva da Biosfera e aos Mosaicos de Áreas Protegidas.

A primeira iniciativa de mosaico no Brasil ocorreu anteriormente à institucionalização do SNUC, no Estado do Rio de Janeiro, na década de 1990. Esta primeira iniciativa diz respeito à constituição do Núcleo Regional de Unidades de Conservação- NURUC, em 1997. A promoção da gestão integrada foi o principal objetivo do NURUC. A meta era integrar a administração de dez UCs localizadas no Estado do Rio de Janeiro, visando minimizar passivos de gestão. Após conhecer os resultados de suas atividades, os gestores do NURUC passaram a divulgar as vantagens do modelo orientado pela gestão integrada de UCs em encontros institucionais, estimulando sua prática (Boletim da Cooperação Brasil-França sobre Áreas Protegidas, 2010).

Atualmente, existem quatorze mosaicos federais reconhecidos no Brasil, dos quais sete estão localizados no bioma Mata Atlântica. Os mosaicos da Mata Atlântica foram criados no período entre 2005-2010, com o objetivo de frear o processo de fragmentação florestal do bioma ou minimizar seus efeitos por meio da gestão integrada das UCs. A análise dos mapas dos mosaicos, localizados na Mata Atlântica, constantes no banco de dados do ICMbio, evidencia a conexão estrutural entre as UCs dos mosaicos situados neste bioma. Esta conformação geográfica dos mosaicos da Mata Atlântica contribui para impedir novos processos de fragmentação florestal, bem como assegura áreas extensas para a conservação, muitas vezes necessária à sobrevivência de determinadas espécies.

No Bioma Floresta Amazônica, existem três mosaicos federais reconhecidos. A área total coberta pelos mosaicos neste bioma é de aproximadamente 26,0 milhões de hectares. Assim como para a Mata Atlântica, a análise dos mapas dos mosaicos localizados na Amazônia, conforme banco de dados do ICMbio, evidencia a conectividade estrutural entre as UCs. A diferença é que no Bioma Floresta Amazônica o processo de fragmentação florestal não é tão intenso como na Mata Atlântica. 
Por este motivo, o enfrentamento do problema relacionado à fragmentação florestal não é o principal motivador para a criação de mosaicos no Bioma Floresta Amazônica. As análises realizadas para a presente pesquisa sugerem que, no caso do Mosaico do Baixo Rio Negro, a principal motivação para sua criação refere-se à promoção da gestão integrada e participativa. Na região do Baixo Rio Negro, anteriormente à constituição do mosaico, as UCs já encontravam-se conectadas estruturalmente umas às outras no espaço geográfico, formando um bloco contínuo extenso de áreas protegidas, representando uma barreira ao processo de fragmentação florestal.

Assim, os estudos realizados para a presente pesquisa sugerem que o aspecto que norteou a criação do Mosaico do Baixo Rio Negro está relacionado com a promoção da gestão integrada e participativa para otimizar recursos e atividades em prol da conservação e para se pensar o território de forma conjunta, envolvendo as populações locais, para que as comunidades se aproximem das áreas protegidas e, desde modo, passem a contribuir com a conservação.

Para Irving (2014), o processo de criação de UCs tem sido conduzido, com raras exceções de modo centralizado, burocrático e autoritário, orientado por argumentos ecológicos dissociados do contexto socioeconômico, principalmente durante o período anterior ao SNUC, pois somente a partir do SNUC é que se tornaram obrigatórias as consultas públicas nos processos de criação das UCs. Esta prática gerou conflitos socioambientais nas UCs criadas, dificultando a gestão favorável à conservação. O Mosaico do Baixo Rio Negro, ao estabelecer como um de seus principais objetivos a gestão participativa, tende a contribuir para diminuir os conflitos socioambientais que ocorrem na região, os quais representam um obstáculo à gestão orientada para a conservação ambiental.

Para Irving (2014), o momento atual é marcado por tentativas de reconexão entre sociedade e natureza, em outras palavras, pelo "religare", para se pensar novos rumos para a gestão de áreas protegidas. Isto porque historicamente construiu-se um distanciamento entre sociedade e natureza, principalmente em razão da ideologia pósindustrial moderna. Assim, a gestão participativa de áreas protegidas requer uma desconstrução de mitos históricos e um novo olhar. O Mosaico do Baixo Rio Negro tende a insere-se nesta nova perspectiva de gestão de áreas protegidas na medida em que vem se empenhando para promover a gestão participativa. 
O Mosaico do Baixo Rio Negro tende a contribuir para que o Brasil atenda às recomendações da $\mathrm{CDB}$, da qual é membro signatário. Isto porque a CDB recomenda que a gestão de áreas protegidas seja conduzida de forma participativa e democrática, sugerindo um novo tipo de governança, algo que o Mosaico vem buscando. Da mesma forma, o Mosaico tende a contribuir para que o Brasil atenda às recomendações da IUCN, que a partir da Declaração de Durban de 2003, vem progressivamente internalizando as recomendações para a gestão participativa de áreas protegidas.

No entanto, uma das lacunas identificadas para o Mosaico, por meio das análises realizadas para a presente pesquisa, refere-se à ausência de um sistema de avaliação da governança, de modo que seja possível aferir a qualidade da gestão participativa que nele ocorre. Neste aspecto, o Mosaico não vem contribuindo com o alcance de algumas metas específicas estabelecidas na CDB, visto que na COP 10, realizada em Nagoya, em 2010, ficou estabelecido que os países signatários devem conduzir avaliações sistemáticas de governança em áreas protegidas a partir de ferramentas construídas pela Secretaria da CDB e outras instituições.

No estudo de caso conduzido para a presente pesquisa, evidenciou-se que o Mosaico não conta com apoio suficiente por parte do Governo Federal. Não existem recursos deste setor governamental destinados ao Mosaico, com exceção dos recursos que foram previstos no Edital do FNMA № 01/2005, dos quais apenas uma parte foi repassada para, tendo já expirado seu prazo. Além disso, conforme citado em entrevista com gestor de órgão ambiental federal, os gestores governamentais dividem-se ideologicamente com relação aos mosaicos, muitos opondo-se a eles, o que também dificulta a operacionalização dos mosaicos.

O Mosaico do Baixo Rio Negro vem despontando como força política favorável à conservação e ao desenvolvimento sustentável na região. O Conselho atua a partir da cobrança às instituições competentes, pelas ações devidas pertinentes à conservação e direitos das populações locais, por meio da elaboração e envio de moções. Conforme analisado na presente pesquisa, a força política exercida pelo Conselho precisa ser incrementada, pois em diversas ocasiões, o Conselho não obteve respostas para suas reivindicações. 
A ampliação da força política do Mosaico do Baixo Rio Negro tende a resultar em incremento na conservação da biodiversidade da região. O intercâmbio entre os gestores de mosaicos é importante para a troca de experiência, aprendizado e para unir os gestores. A consolidação de uma força política em prol da conservação ambiental é fundamental para o enfrentamento das ameaças atuais ao meio ambiente, como o desmatamento praticado por madeireiras ilegais, o agronegócio, a pesca comercial predatória e a mineração. A criação de áreas protegidas isoladas, tendo como modelo de gestão a centralização no gestor da unidade representa um retrocesso ao período inicial de implementação desta política e não se insere no contexto atual marcado pela necessidade do "religare". A gestão integrada e participativa de áreas protegidas é um caminho inevitável.

A pesquisa aqui apresentada demonstrou que o Conselho do Mosaico do Baixo Rio Negro vem atuando de forma mais eficiente que os Conselhos das UCs individualizados, pois o CCMBRN transmite maior confiança para os representantes das comunidades locais e vem solucionando os problemas socioambientais existentes na região de forma mais efetiva que os Conselhos das UCs. 


\section{Referências}

ACACCIO, Gustavo de Matos. et al. A fragmentação dos ecossistemas e a biodiversidade brasileira: uma síntese. In: OLIVEIRA, Daniela América Suarez; RAMBALDI, Denise Marçal (Orgs). Fragmentação de ecossistemas: causas, efeitos sobre a biodiversidade e recomendações de políticas públicas. Série Biodiversidade, 6 . Brasília: Ministério do Meio Ambiente, 2003, Seção III, p. 317-326.

ALBUQUERQUE, João Lucílio; LINO, Clayton Ferreira (Orgs). Mosaicos de Unidades de Conservação no Corredor da Serra do Mar. Caderno da Reserva da Biosfera da Mata Atlântica no 32. Série Conservação e Áreas Protegidas. São Paulo: Conselho Nacional da Reserva da Biosfera da Mata Atlântica, 2007.

ALENCAR, Ane. et al. REDD no Brasil: um enfoque amazônico. 3. ed. Brasília: Centro de Gestão e Estudos Estratégicos- CGEE; Instituto de Pesquisa Ambiental da Amazônia- IPAM; Secretaria de Assuntos Estratégicos da Presidência da RepúblicaSAE, 2012.

ALGER, Keith; LIMA, André. Políticas públicas e a fragmentação de ecossistemas. In: OLIVEIRA, Daniela América Suarez; Rambaldi, Denise Marçal (Orgs). Fragmentação de ecossistemas: causas, efeitos sobre a biodiversidade e recomendações de políticas públicas. Série Biodiversidade, 6. Brasília: MMA, 2003, Seção IV, p. 391- 420.

ARAÚJO, André Luís de Oliveira; DA GAMA, Sônia Vidal Gomes; LIMA, Bianca Ferreira. Caracterização da pecuária na RDS Amanã (AM): desafios e oportunidades para a organização de uma UC de uso sustentável. In: XIX ENCONTRO NACIONAL DE GEÓGRAFOS, 2006, Rio Branco. Anais do XIV Encontro Nacional de Geógrafos. Rio Branco: Associação dos Geógrafos Brasileiros Seção Dourados, 2006. Disponível em:

<http://academia.edu/8091646/Caracterizacao_Pecuaria_de_uma_Unidade_de_Conse rvação_de_Uso_Sustentavel>. Acesso em 11/09/2014.

ARRUDA, Moacir Bueno. Corredores Ecológicos no Brasil: o enfoque ecossistêmico na implementação da Convenção da Biodiversidade. In: ARRUDA, Moacir Bueno (Org.). Gestão integrada de ecossistemas aplicada a corredores ecológicos. 2. ed. Brasília: MMA /IBAMA, 2006, Capítulo 1, p. 19-49.

ARRUDA, Moacir Bueno; SÁ, Luís Fernando S. (Orgs.). Corredores Ecológicos: uma abordagem integradora de ecossistemas no Brasil. Brasília: IBAMA/MMA, 2004.

ASSOCIAÇÃO MICO LEÃO DOURADO. Disponível em: $<$ http://www.micoleao.org.br/template.php?pagina=/ptg/associacao/noticias_visualiza.p hp\&id=74\&link=1>. Acesso em: 17/07/2014.

AZEVEDO, Alexsander Araújo. et al. (Orgs). Mosaico de Unidades de Conservação do Espinhaço/Alto Jequitinhonha/Serra do Cabral: processo de criação e implantação. Instituto Biotrópicos. Minas Gerais. 2009.

BARROS, Camila S.; FERNANDEZ, Fernando Antônio Santos; PIRES, Alexandra S. Vivendo em um mundo em pedaços: efeitos da fragmentação florestal sobre comunidades e populações animais. In: ALVES, Maria Alice Santos. et al. (Orgs). Biologia da Conservação: essências. São Carlos: Rima, 2006, Capítulo 10, p. 231260. 
BARROS, Solange; GUIMARÃES, Solange Terezinha de Lima; RÊGO, Jackson Fernando. Tecendo o tupé: um estudo sobre percepção e interpretação ambiental na RDS do Tupé, Manaus-AM. Geosul, Florianópolis, v. 23, n. 45, p. 85-104, jan./jun. 2008.

BENSUSAN, Nurit. Diversidade e unidade: um dilema constante. Uma breve história da ideia de conservar a natureza em áreas protegidas e seus dilemas. In: BENSUSAN, Nurit; PRATES, Ana Paula (Orgs.). A diversidade cabe na unidade? áreas protegidas no Brasil. Brasília: IEB Mil Folhas, 2014, Capítulo 1, p.30-81.

BILLACRÊS, Máximo Alfonso Rodrigues. et al. Assentamento Tarumã- Mirim (AM): uso do território e políticas públicas. In: XXI Encontro Nacional de Geografia Agrária. 2012, Uberlândia. Anais do XXI Encontro Nacional de Geografia Agrária. Uberlândia: Associação dos Geógrafos Brasileiros, 2012. Disponível em: $<w w w . l a g e a . i g . u f u . b r / x x 1$ enga/anais_enga_2012/eixos/1432_1.pdf $>$. Acesso em: 23/09/2014.

BRANT, Arthur. et al. Fragmentação: Alguns Conceitos. In: OLIVEIRA, Daniela América Suarez; Rambaldi, Denise Marçal (Orgs). Fragmentação de ecossistemas: causas, efeitos sobre a biodiversidade e recomendações de políticas públicas. Brasília: MMA, 2003, Seção I, p. 23- 40.

BRASIL. Constituição Federal de 1988. Disponível em: <http://www.planalto.gov.br/ccivil_03/constituicao/constituicao.htm>. Acesso em: 04/09/2014

BRASIL. Decreto ํo 4.340, de 22 de agosto de 2002. Disponível em: $<$ http://www.planalto.gov.br/ccivil_03/decreto/2002/d4340.htm>. Acesso em: 09/06/2013.

BRASIL. Decreto ํㅜ 5.758, de 13 de abril de 2006. Disponível em: <http://www.planalto.gov.br/ccivil_03/_Ato2004-2006/2006/Decreto/D5758.htm>. Acesso em: 02/06/2013.

BRASIL. Lei no 9.985, de 18 de julho de 2000. Disponível em: <http://www.planalto.gov.br/ccivil_03/leis/19985.htm> Acesso em: 02/03/2014; 03/05/2014; 10/06/2014; 20/09/2014; 15/10/2014; 24/10/2014.

BRASIL. Lei $\mathrm{n}^{\circ}$ 11.428, de 22 de dezembro de 2006. Disponível em: <http://www.planalto.gov.br/ccivil_03/_ato2004-2006/2006/lei/l11428.htm>. Acesso em: 05/11/2014.

BRASIL. Lei no 12.651, de 25 de maio de 2012. Disponível em: <http://www.planalto.gov.br/ccivil_03/_ato2011-2014/2012/lei/l12651.htm>. Acesso em 03/06/2014.

BRASIL. Portaria MMA no 483, de 14 de dezembro de 2010. Disponível em: $<$ www.mma.gov.br/legislacao/areas-protegidas?...821:portaria...483>. Acesso em: 02/04/2014.

BRITEZ, Ricardo Miranda de. et al. Causas naturais. In: OLIVEIRA, Daniela América Suares; RAMBALDI, Denise Marçal (Orgs). Fragmentação de ecossistemas: causas, efeitos sobre a biodiversidade e recomendações de políticas públicas. Série Biodiversidade, 6. Brasília: MMA, 2003, Seção II, p. 44-63.

CADASTRO NACIONAL DE RPPNs. Disponível em: <http://www.reservasparticulares.org.br/>. Acesso em: 23/07/2014. 
CADASTRO NACIONAL DE UNIDADES DE CONSERVAÇÃO. Disponível em: $<$ http://www.mma.gov.br/areas-protegidas/cadastro-nacional-de-ucs/dadosconsolidados>. Acesso em: 05/11/2014.

CARDOSO, Thiago Mota; DELELIS, Caroline Jeanne; REHDER, Tatiana. Mosaicos de Áreas Protegidas: reflexões e propostas da Cooperação FrancoBrasileira. Série Áreas Protegidas. Brasília: MMA, Embaixada da França no Brasil e CDS-UnB. 2010.

CARDOSO, Thiago Mota. et al. Territórios da sustentabilidade: Mosaicos de Áreas Protegidas como ferramenta de gestão e desenvolvimento territorial na Amazônia brasileira. In: XI COLÓQUIO INTERNACIONAL SOBRE PODER LOCAL, DESENVOLVIMENTO E GESTÃO SOCIAL DE TERRITÓRIOS, 2009, Salvador. Caderno de Resumos, Salvador: Centro Interdisciplinar de Desenvolvimento e Gestão Social/ Universidade Federal da Bahia, 2009. Disponível em: $<$ www.gestaosocial.org.br/sistema/imagens/caderno_resumo_Final.pdf $>$. Acesso em: 23/09/2014.

CARDOSO, Thiago Mota. et al. Os povos tradicionais e o ordenamento territorial no baixo rio negro em uma perspectiva da conservação e uso sustentável da biodiversidade. In: ARMSTRONG, Gordon; BENSUSAN, Nurit (Orgs). O manejo da paisagem e a paisagem do manejo. Brasília: Instituto Internacional de Educação no Brasil, 2008, Capítulo 3, p. 37-67.

CASES, Maria Olatz. et al. Memórias do Seminário de Mosaico de Áreas Protegidas no Amazonas- 2007. In: SEMINÁRIO MOSAICOS DE ÁREAS PROTEGIDAS NO AMAZONAS, 2007, Manaus: WWF, ARPA, GTZ, CEUC, e SDS, $2007 . \quad$ Disponível em: $<$ d3nehc6yl9qzo4.cloudfront.net/.../memoriaseminariogestaomosaicos.pdf $>$. Acesso em 23/09/2014.

CONSERVAÇÃO INTERNACIONAL. Disponível em: <http://www.conservation.org.br/como/index.php?id=8>. Acesso em: 22/07/2014.

COOPERAÇÃO TÉCNICA ALEMÃ- GTZ. Disponível em: <http://eb.mit.edu/urbanupgrading/upgrading/resources/organizations/gtz.html>. Acesso em: 10/07/2014.

DAVENPORT, Lisa; RAO, Madhu. A história da proteção: paradoxos do passado e desafios do futuro. In: DAVENPORT, Lisa. et al. (Orgs). Tornando os parques eficientes: estratégia para a conservação da natureza nos trópicos. Curitiba: UFPR, 2002, Capítulo 3, p. 52-72.

DIÁRIO DO AMAZONAS. Disponível em: $<$ http://new.d24am.com/amazonia/meio-ambiente/ministra-assina-portaria-paracriacao-do-mosaico-meridional/34139>. Acesso em: 17/07/2014.

DICIONÁRIO ONLINE DE PORTUGUÊS. Disponível em: <www.dicio.com.br/mocao>. Acesso em: 16/10/2014.

DRUMMOND, José Augusto; FRANCO, José Luiz de Andrade. Terras de Quilombolas e Unidades de Conservação: uma discussão conceitual e política, com ênfase nos prejuízos para a conservação da natureza. Grupo Iguaçu. 2009. Disponível em: <http:// www.grupoiguacu.net>. Acesso em: 08/08/2014.

DRUMMOND, José Augusto; FRANCO, José Luiz de Andrade; OLIVEIRA, Daniela. Uma análise sobre a história e a situação das unidades de conservação no 
Brasil. In: GANEM, Roseli Senna (Org.). Conservação da biodiversidade: legislação e políticas públicas. Série Memória e Análise de Leis. n. 02. Brasília: Câmara dos Deputados, 2010, p. 341-387.

FUNDAÇÃO AMAZÔNIA SUSTENTÁVEL. Disponível em: <http://fasamazonas.org/2010/05/projeto-de-redd-do-mosaico-do-apui-e-iniciado/?lang=pt>. Acesso em: 17/07/2014.

FUNDAÇÃO NACIONAL DO ÍNDIO- FUNAI. Disponível em: $<$ http://www.funai.gov.br>. Acesso em: 04/09/2014.

FUNDAÇÃO PRÓ-NATUREZA- FUNATURA. Disponível em: $<$ http://www.funatura.org.br/index.php/projetos/grande-sertao-veredas>. Acesso em: $17 / 07 / 2014$.

FUNDAÇÃO VITÓRIA AMAZÔNICA. Unini- 0 rio da sustentabilidade: bases socioambientais para a gestão da bacia do rio unini e de suas unidades de conservação. Manaus: Fundação Vitória Amazônica, 2011.

FUNDO MUNDIAL PARA A NATUREZA- WWF. Disponível em <http://www.wwf.org.br/natureza_brasileira/especiais/mam/>. Acesso em: 17/07/2014.

GANEM, Roseli Senna. Gestão integrada da biodiversidade: Corredores, Mosaicos e Reservas da Biosfera. In: GANEM, Roseli Senna (Org.). Conservação da biodiversidade: legislação e políticas públicas. Série Memória e Análise de Leis. n. 02. Brasília: Câmara dos Deputados, 2011, p. 387-415.

GHILARDI, Rubens Júnior; SARACURA, Valéria e SILVA, Márcio Oliveira. Mosaico de Unidades de Conservação da Região da UHE Tucuruí: implementação de um modelo de gestão ambiental para o reservatório. In: XXVII SEMINÁRIO NACIONAL DE GRANDES BARRAGENS, 2007, Belém. Anais do XXVII Seminário Nacional de Grandes Barragens. Belém: Comitê Brasileiro de Barragens, 2007. Disponível em <www.cbdb.org.br/seminario/belem/T99/A16.PDF>. Acesso em: 14/07/2014.

GRUPO BANCÁRIO KFW. Disponível em: <https://www.kfwentwicklungsbank.de/International-financing/KfW-Entwicklungsbank/About-us/>. Acesso em: 10/07/2014.

INOUÊ, Cristina Yumie Aoki. Regime global de biodiversidade: o caso Mamirauá. Brasília: Editora UnB, 2007.

INSTITUTO BRASILEIRO DE MEIO AMBIENTE E DOS RECURSOS NATURAIS RENOVÁVEIS- IBAMA. Disponível em: <www.ibama.gov.br>. Acesso em: 03/02/2014.

INSTITUTO CHICO MENDES DE CONSERVAÇÃO DA BIODIVERSIDADEICMbio. Disponível em: <www.icmbio.gov.br/portal/o-que-fazemos/corredoresecologicos/mosaicos-reconhecidos-oficialmente.html>. Acesso em: 11/07/2014.

INSTITUTO DE DESENVOLVIMENTO SUSTENTÁVEL DE MAMIRAUÁ- IDSM. Disponível em <http://www.mamiraua.org.br/pt-br>. Acesso em: 03/06/2014.

INSTITUTO DE PESQUISA AMBIENTAL DA AMAZÔNIA- IPAM. Disponível em: <http://www.ipam.org.br/saiba-mais/glossariotermo/Arco-do-desmatamento/92>. Acesso em: 22/07/2014. 
INSTITUTO DE PESQUISAS ECOLÓGICAS- IPÊ. Disponível em: <http://www.ipe.org.br/projetos-baixo-rio-negro/projeto-mosaico-de-areas-protegidas>. Acesso em: 15/07/2014.

INSTITUTO ECOBRASIL. Disponível em: $<$ http://www.ecobrasil.org.br/publique/cgi/cgilua.exe/sys/start.htm?infoid=257\&sid=53>. Acesso em: 15/07/2014.

INSTITUTO SOCIOAMBIENTAL- ISA. Disponível em <http://uc.socioambiental.org >. Acesso em: 03/02/2014.

IRVING, Marta de Azevedo. Governança democrática e gestão participativa de áreas protegidas: um caminho sem volta para a conservação da biodiversidade no caso brasileiro. In: BENSUSAN, Nurit; PRATES, Ana Paula (Orgs). A diversidade cabe na unidade? áreas protegidas no Brasil. Brasília: IEB Mil Folhas, 2014, Capítulo 5, p. 166183.

LEONARDI, Victor. Os historiadores e os rios: natureza e ruína na Amazônia brasileira. Brasília: Paralelo 15, Universidade de Brasília, 1999.

LINO, Clayton Ferreira. Mosaico de Unidades de Conservação do Jacupiranga. Caderno da Reserva da Biosfera da Mata Atlântica no 37 . Série Conservação e Áreas Protegidas. São Paulo: Conselho Nacional da Reserva da Biosfera da Mata Atlântica, 2009. Disponível em: <www.rbma.org.br/rbma/pdf/caderno_37.pdf>. Acesso em: 20/06/2014.

MACEDO, Heitor Schulz; MENDONÇA, Felipe Cruz; TALBOT, Virgínia. Reflexões sobre a participação social em unidades de conservação e a contribuição do Instituto Chico Mendes de Conservação da Biodiversidade. In: BENSUSAN, Nurit; PRATES, Ana Paula (Orgs.). A diversidade cabe na unidade? áreas protegidas no Brasil. Brasília: IEB Mil Folhas, 2014, Capítulo 9, p. 268-307.

MACIEL, Bruno Amorim. Mosaicos de unidades de conservação: uma estratégia de conservação para a Mata Atlântica. 2007. Dissertação (Mestrado em Desenvolvimento Sustentável) Centro de Desenvolvimento Sustentável, Universidade de Brasília, Brasília.

MAPA TURÍSTICO DE ANAVILHANAS 2014. Série Parques Brasileiros. SEBRAE, PARNA Anavilhanas, ICMbio, ABETA e Ministério do Turismo.

MILLER, Kenton. Planejamento Biorregional. Brasília: IBAMA, 1997.

MINISTÉRIO DO MEIO AMBIENTE. Disponível em: <www.mma.gov.br>. Acesso em: 09/06/2014.

MINISTÉRIO DO MEIO AMBIENTE. Edital FNMA no 01/2005: Mosaicos de Áreas Protegidas- uma estratégia de DTBC. Disponível em: <www.mma.gov.br/apoioa-projetos/fundonacional>. Acesso em: 10/09/2013.

MOSAICO MANTIQUEIRA DE UNIDADES DE CONSERVAÇÃO. Disponível em: <www.mosaicomantiqueira.org.br/site/o-mosaico/>. Acesso em: 15/07/2014.

PAINEL INTERGOVERNAMENTAL DE MUDANÇAS CLIMÁTICAS- IPCC. $<$ http://www.ipcc.ch/>. Acesso em: 07/11/2014.

PERALTA, Nelissa; QUEIROZ, Helder. Reserva de Desenvolvimento Sustentável: manejo integrado dos recursos naturais e gestão participativa. In: BECKER, Bertha e GARAY, Irene. Dimensões humanas da biodiversidade. Petrópolis: Vozes, 2006. p.447- 477. 
PRATES, Ana Paula; SOUSA, Nadinni. Panorama Geral das Áreas Protegidas no Brasil: desafios para o cumprimento da meta 11 de Aichi. In: BENSUSAN, Nurit; PRATES, Ana Paula (Orgs.). A diversidade cabe na unidade? áreas protegidas no Brasil. Brasília: IEB Mil Folhas, 2014, Capítulo 2, p. 82-119.

PRIMACK, Richard B.; RODRIGUES, Efraim. Biologia da Conservação. Londrina: Editora Rodrigues, 2001.

PROGRAMA ÁREAS PROTEGIDAS DA AMAZÔNIA- ARPA. Disponível em: <www.programaarpa.gov.br>. Acesso em: 04/07/2014; 10/10/2014.

REDE DE MOSAICOS. Disponível em: <www.redemosaicos.com.br>. Acesso em: 10/06/2014.

REDE MOSAICOS. Boletim da Cooperação Brasil-França sobre Áreas Protegidas № 09, Abril/Maio de 2010. Disponível em: <http:// www.redemosaicos.com.br/arquivos_dados/arq.../mmidia-id-13.pdf>. Acesso em: 02/08/2014.

RESERVA DA BIOSFERA DA MATA ATLÂNTICA. Disponível em:

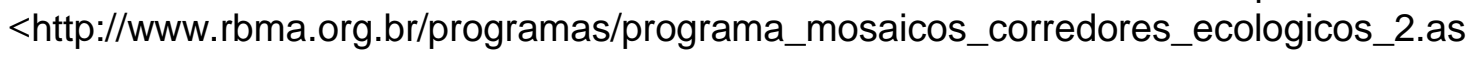
p>. Acesso em: 16/07/2014.

SECRETARIA MUNICIPAL DE MEIO AMBIENTE E SUSTENTABILIDADE DE MANAUS. Disponível em: <http://semmas.manaus.am.gov.br/unidades-deconservaçao/>. Acesso em: 11/09/2014.

$\begin{array}{lcc}\text { SISTEMA DE INDICADORES SOCIOAMBIENTAIS PARA UNIDADES DE } & \text { PE } \\ \text { CONSERVAÇÃO-SISUC. } & \text { Disponível } & \text { em }\end{array}$ <http://blogdosisuc.socioambiental.org/node/328>. Acesso em: 20/08/2014.

UNIÃO INTERNACIONAL PARA CONSERVAÇÃO DA NATUREZA- IUCN. Disponível em: <www.iucn.org>. Acesso em: 02/06/2014.

ZIMMERER, Karl S. Conservation booms with agricultural growth? sustainability and shifting environmental governance in latin america, 1985-2008, Mexico, Costa Rica, Brazil, Peru, Bolivia. Latin America Research Review. Special Issue. 2011. 


\section{ANEXOS \\ ROTEIROS DAS ENTREVISTAS SEMIESTRUTURADAS}

Representantes do Governo (Federal, Estadual e Municipal)

Nome do entrevistado:

Instituição:

Data:

Hora:

Local:

\section{Histórico do MBRN:}

1- Qual foi a motivação para a criação do Mosaico?

2- Qual foi seu papel na criação do Mosaico?

3- Qual foi o papel de sua instituição na criação do Mosaico?

4- Como se deu o processo de criação do Mosaico?

5- Quais foram as dificuldades encontradas durante o processo de criação do Mosaico?

6- Quais eram os objetivos iniciais do Mosaico?

\section{A Gestão Atual do Mosaico:}

1- O que você entende ser o Mosaico do Baixo Rio Negro-MBRN?

2- Por que ele é importante?

3- Como vem sendo feita a gestão no Mosaico?

4- Como sua instituição contribui na gestão do mosaico?

5- Como ela vem dialogando com as demais entidades envolvidas na gestão do Mosaico?

6- De que modo você percebe o envolvimento das demais entidades na gestão do mosaico? 
7- Quais são os principais mecanismos de gestão empregados no MBRN?

8- Como o Conselho Consultivo vem atuando na gestão do Mosaico? Com que periodicidade se reúne? Quais os principais temas tratados em suas reuniões? Por que são priorizados esses temas?

9- Como ocorre a operacionalização para a realização das atividades de gestão do Mosaico, com relação ao transporte, recursos financeiros, comunicação, dentre outros aspectos?

10- Quais são as principais dificuldades de gestão do Mosaico?

11- Que resultados positivos já foram percebidos para o Mosaico? Em outras palavras, estão sendo alcançados os objetivos de conservação e desenvolvimento sustentável das comunidades locais traçados para o Mosaico?

12- Quais projetos vêm sendo desenvolvidos para o alcance dos objetivos traçados para o Mosaico? Há perspectiva para o desenvolvimento de novos projetos no Mosaico?

13- Quais são as fontes de financiamento que viabilizam a gestão do MBRN?

14- Em quais atividades estão sendo aplicados os recursos financeiros do MBRN?

15- Como se dá a repartição dos recursos financeiros do MBRN entre as UCs?

16- Quais são as perspectivas futuras com relação à captação de recursos para viabilizar a gestão do Mosaico?

17- Como vem ocorrendo a troca de informações no Mosaico?

18- Como você avalia a gestão atual do Mosaico?

19- Quais são as perspectivas futuras para o Mosaico?

Representantes das ONGs e das organizações da sociedade civil organizada.

\section{Histórico do MBRN:}

1- Qual foi a motivação para a criação do MBRN?

2- Qual foi seu papel na criação do Mosaico?

3- Qual foi o papel de sua instituição na criação do Mosaico?

4- Como se deu o processo de criação do Mosaico?

5- Quais foram as dificuldades encontradas durante o processo de criação do Mosaico?

6- Quais eram os objetivos iniciais do Mosaico? 


\section{A Gestão Atual do Mosaico:}

1- O que você entende ser o MBRN?

2- Por que ele é importante?

3- Qual o papel de sua instituição na gestão do Mosaico?

4- Como ela vem atuando na gestão do Mosaico?

5- Como vem sendo realizada a gestão do MBRN?

6- Como ocorre a operacionalização para viabilizar as atividades de gestão do mosaico, em termos de transporte, comunicação entre as diversas entidades envolvidas, recursos financeiros, dentre outros aspectos?

7- Como vem ocorrendo o diálogo entre sua instituição e as demais entidades participantes da gestão do Mosaico?

8- Como você percebe a atuação das demais entidades na gestão do Mosaico?

9- Quais são as principais dificuldades percebidas com relação à gestão do Mosaico?

10- Quais são os principais resultados positivos percebidos?

11- Existem projetos desenvolvidos no Mosaico que contribuem para o alcance de seus objetivos? Há previsão para o desenvolvimento de novos projetos no Mosaico?

12- Quais são as fontes de financiamento que viabilizam a gestão do MBRN?

13- Em quais atividades estão sendo aplicados os recursos financeiros do MBRN?

14- Quais são as perspectivas futuras com relação à captação de recursos para o Mosaico?

15- Como vem ocorrendo a troca de informações no Mosaico?

16- Como você avalia a gestão atual do Mosaico?

17- Quais são as perspectivas futuras para o Mosaico?

\section{Representantes do setor privado.}

\section{Histórico do MBRN:}

1- Sua empresa participou da criação do MBRN? Se sim, descreva como ocorreu esta participação, qual foi o papel de sua empresa no processo de constituição do mosaico?

2- Caso sua empresa tenha participado do processo de criação do MBRN, na sua opinião, qual foi a principal motivação para a criação do Mosaico? Quais foram as 
principais dificuldades encontradas e quais foram os objetivos iniciais traçados para o Mosaico?

\section{A Gestão Atual do Mosaico:}

1- O que você entende ser o MBRN?

2- Por que ele é importante?

3- Qual o papel de sua instituição na gestão do Mosaico?

4- Como ela vem atuando na gestão do Mosaico?

5- Como vem sendo realizada a gestão do MBRN?

6- Como ocorre a operacionalização para viabilizar as atividades de gestão do mosaico, em termos de transporte, comunicação entre as diversas entidades envolvidas, recursos financeiros, dentre outros aspectos?

7- Como vem ocorrendo o diálogo entre sua instituição e as demais entidades participantes da gestão do Mosaico?

8- Como você percebe a atuação das demais entidades na gestão do Mosaico?

9- Quais são as principais dificuldades percebidas com relação à gestão do Mosaico?

10- Quais são os principais resultados positivos percebidos?

11- Existem projetos desenvolvidos no Mosaico que contribuem para o alcance de seus objetivos? Há previsão para o desenvolvimento de novos projetos no Mosaico?

12- Quais são as fontes de financiamento que viabilizam a gestão do MBRN?

13- Em quais atividades estão sendo aplicados os recursos financeiros do MBRN?

14- Quais são as perspectivas futuras com relação à captação de recursos para o Mosaico?

15- Como vem ocorrendo a troca de informações no Mosaico?

16- Como você avalia a gestão atual do Mosaico?

17- Quais são as perspectivas futuras para o Mosaico?

\section{Representantes das comunidades.}

\section{A História do MBRN:}

1- Sua comunidade participou da criação do MBRN? Se ela participou, como foi esta participação?

2- Caso sua comunidade tenha participado da criação do MBRN, na sua opinião, por que você acha que foi criado este Mosaico?

3- Por que sua comunidade participou/não participou da criação do Mosaico?

4- Você pode me contar como aconteceu a criação deste Mosaico 


\section{Como o Mosaico funciona:}

1- Na sua opinião, o que que é esse Mosaico do Baixo Rio Negro?

2- Para que que ele serve?

3- Sua comunidade participa dele? Se sim, como ela participa? Se não, por que que ela não participa?

4- Você sabe quem participa do Mosaico?

5- Você conversa com essas pessoas sobre o Mosaico? Se sim, o que você conversa com elas?

6- Sua comunidade tem interesse no Mosaico? Se sim, por que? Se não, por que não?

7- A sua comunidade já foi beneficiada pelo Mosaico? Se sim, como?

8- A sua comunidade recebe informações sobre o Mosaico? Se sim, quem informa vocês e como?

9- Existe alguma ação do Mosaico que está sendo feita lá na sua comunidade? Por exemplo, de educação ambiental ou de exploração sustentável dos recursos naturais (com respeito ao meio ambiente e ao modo de vida de sua comunidade)?

10- Você acha que o Mosaico valoriza sua cultura, seu modo de viver e de produzir? Se sim, por que? Se não, por que não. 